\title{
Výsledky záchranného archeologického výzkumu na předhradí hradu Tepence v letech 1971-1975
}

\author{
The results of the rescue excavation in the outer bailey of \\ Tepenec Castle in 1971-1975 \\ - Lukáš Hlubek* -
}

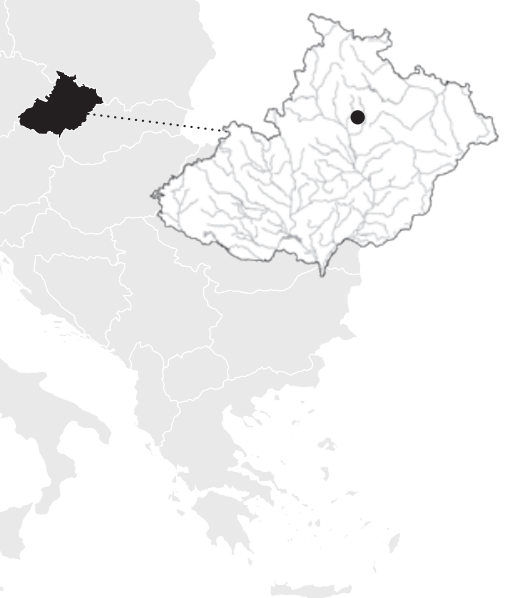

\section{KEYWORDS}

Moravia - Tepenec Castle - outer bailey - built-up area - Middle Ages pottery - iron artefacts

\section{ABSTRACT}

The present study evaluates the medieval component of a rescue excavation carried out in the outer bailey of Tepenec Castle in 1971-1975. The castle, built during the 1330 s-40s, ceased to exist due to war events in the early 15 th century. A trench intersected the whole area of the fortified complex transversely from the northwest to the southeast $(855 \mathrm{sqm})$. Two remnants of buildings dated to the High Middle Ages were partially examined. An assemblage of pottery and metal finds makes it possible to date both structures mainly to the second half of the 14th and the early 15th centuries. The built-up area of the outer bailey cannot be considered a lower castle town but rather the so-called "latrán".

\footnotetext{
*Corresponding author - E-mail address: hlubek@vmo.cz

https://doi.org/10.47382/pv0622-03
}

Received 24 June 2021; received in revised form 9 September 2021. Available online 30 December 2021

Copyright (c) 2021 Czech Acad Sci, Inst Archaeology Brno, and the authors. This is an open access article under the CC BY-NC-ND 4.0 license (https://creativecommons.org/licenses/by-nc-nd/4.0/).

Competing interests: The authors have declared that no competing interests exist.

\section{1. Úvod}

Už v 19. století se v literatuře objevují zmínky o hradě Tepenci, ${ }^{1}$ který založil markrabě Karel, pozdější římský císař a český král Karel IV. (Wolny 1846, 428-429; Protivanovský 1877, 78; Prasek 1883, 72-75; Stief 1896, 72-73). ${ }^{2}$ Jde o jediný hrad vystavěný Karlem IV. na Moravě. Na jím zvoleném místě původně existovalo hradisko lužické kultury s dochovaným valovým opevněním. Bohužel v blízkosti lokality byl v 19. století otevřen kamenolom, jenž začal naleziště postupně odtěžovat. Z těchto důvodů zde probíhají záchranné archeologické výzkumy od roku 1968 a s přestávkami pokračují v podstatě dodnes. ${ }^{3}$ V prvních etapách výzkumu (1968-1971) bylo z větší části prozkoumáno hradní jádro a od roku 1971 až doposud probíhají terénní práce na ploše rozsáhlého předhradí, které zaujímalo prostor dřívějšího pravěkého hradiska.

I přes snahu všech vedoucích záchranných výzkumů se dosud nepodařilo řádně vyhodnotit veškerá dostupná data, byt jen z jedné výzkumné sezóny. Předložený text stručně shrnuje zveřejněné výsledky a zaměřuje se na zpracování stř̌edověkých nálezů z výzkumu provedeného v letech 1971-1975 pod vedením Víta Dohnala. ${ }^{4} \mathrm{Z}$ tohoto výzkumu disponujeme pouze krátkými zprávami o odkrytých nálezových situacích z doby fungování hradu (Dohnal 1972, 63-64; 1974, 35; 1975, 26; 1977, 21-22), nebot' vedoucího výzkumu zajímalo především pravěké osídlení lokality. ${ }^{5}$ Nicméně jím dva částečně zachycené objekty datované do vrcholného stř̌edověku si zaslouží kompletní zveřejnění, protože poprvé doložily osídlení v areálu předhradí během fungování hradu.

\section{Poloha a popis hradu Tepence}

Hrad se nachází v jihozápadní části katastrálního území obce Jívové (okr. Olomouc) asi 2,5 km západně od centra obce. Lokalita se tyčí nad Bělkovickým údolím (obr. 1), kterým protéká Trusovický potok. Hrad a předhradí se rozkládají na oválné ostrožně, jež leží západně od kopce Koruna (573,6 m n. m.). Ostrožna má delší osu ve směru severovýchod-jihozápad. Na severozápadě a západě spadají prudké svahy do Bělkovického údolí a na jihovýchodě a jihu klesá terén do údolí bezejmenného potoka. Ostrožna je s okolím spojena pouze na východní až jihovýchodní straně, kde byl do skály vysekán šíjový př́íkop. Nejvyšší bod předhradí (519 m n. m.) je situován hned za šíjovým př́íkopem na východní straně. Odtud výška postupně klesá do sedla a znovu se původně zvedala směrem k západnímu skalnatému výběžku (509 m n. m.), kde se nad údolím rozkládalo středověké jádro hradu (obr. 2).

Blíže neznámá část tohoto hradního jádra se nedochovala vlivem eroze a také v důsledku těžby v blízkém kamenolomu. Na základě archeologického výzkumu Václava Buriana měl vlastní hrad přibližně trojúhelníkovitý půdorys (obr. 3). U konce ostrožny byla odkryta torzálně dochovaná budova (obr. 3: 1). Podařilo se zde 


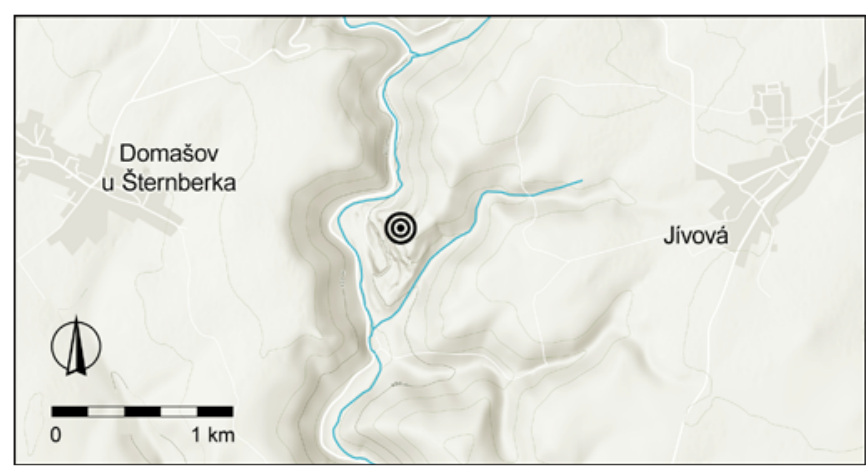

Obr. 1. Hrad Tepenec. Poloha studované lokality. Podle Vránová, Vrána 2016, obr. 3, upraveno.

Fig. 1. Tepenec Castle. Location of the site under study. After Vránová, Vrána 2016, Fig. 3, modified.

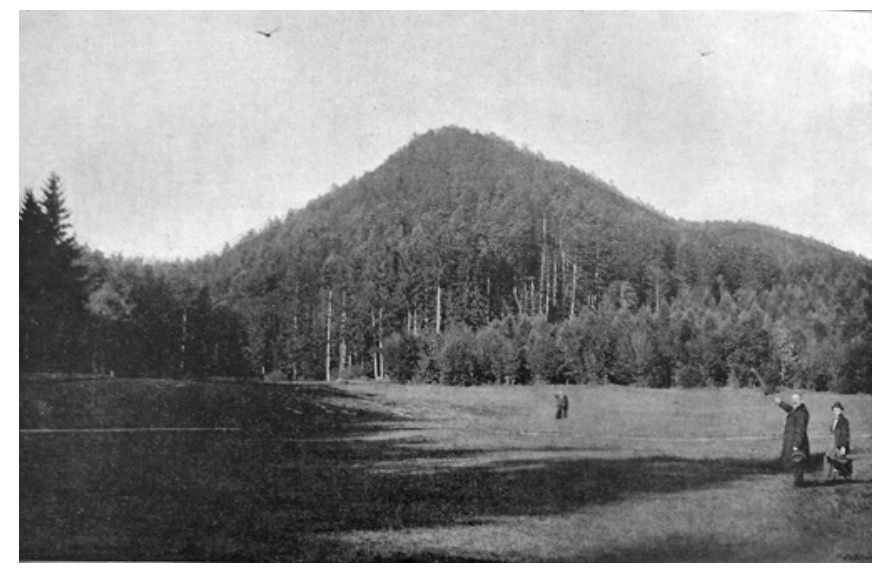

Obr. 2. Hrad Tepenec. Pohled na kopec s hradem z Bělkovického údolí kolem roku 1900. Podle Anonym 1900, 60.

Fig. 2. Tepenec Castle. View of the hill and castle from Bělkovice Valley around 1900 After Anonymous 1900, 60.

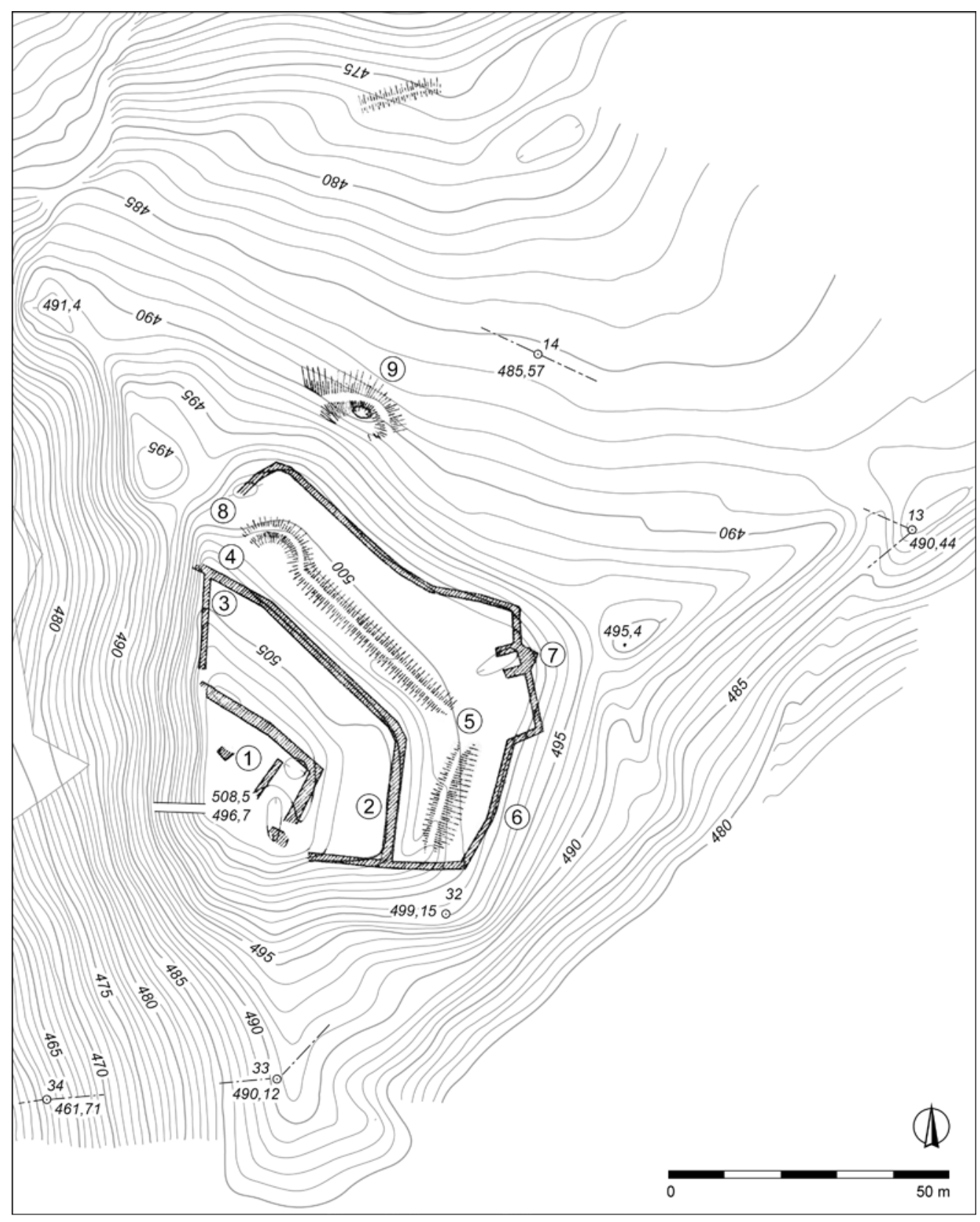

Obr. 3. Hrad Tepenec. Odkryté jádro hradu na základě výzkumů v letech 1968-1971. Podle Burian 1979a, obr. 3. Fig. 3. Tepenec Castle. Excavated core of the castle based on excavations conducted in 1968-1971. After Burian 1979a, Fig. 3. 
prozkoumat nároží vnitřně členěného paláce nebo věže, na kterou mohl navazovat druhý palác, popřípadě druhá věž. Delší odhalená zed' dosahovala délky $27,5 \mathrm{~m}$ a směřovala k severozápadu. Kratší měla délku $12 \mathrm{~m}$ a vedla jihozápadním směrem. Obě popsané zdi byly spojeny kvalitní vápennou maltou a dosahovaly mocnosti 2,2 m. Rovnoběžně s kratší zdí byla zjištěna druhá kamenná zed’ o síle $1 \mathrm{~m}$, která nejspíše tvořila vnitřní zdivo (popřípadě příčku) budovy (např. Plaček 2001, 640, obr. 1241). U okraje srázu zdokumentoval V. Burian (1971a, 2-3) kus zdiva o minimální šířce 3,3 m. V roce 1972 objevil konzervátor M. Cop kamenné zdivo poblíž srázu. Podle V. Buriana to představovalo důkaz, že „objekty hradního paláce pokračovaly dále jihozápadním směrem a z velké části zanikly odlučností skalní stěny" (Burian 1972a, 7). Další nevelké torzo zdiva bylo objeveno severozápadním směrem (Burian 1971, 2-3). Výzkumem obnažené zdi dosahovaly do výšky maximálně jednoho metru. $Z$ prostoru jádra pocházejí také fragmenty cihel, které mohly být použity jak při vyzdívání okenních otvorů, tak i zazdívání trámů. Kupodivu z prostoru paláce neevidujeme zlomky stř̌ešní krytiny ani podlahových dlaždic. Během výzkumu nebyly nalezeny žádné kamenické články (např. ostění, konzoly atd.). S provozem hradu lze spojit pouze nalezené fragmenty nádobkových kachlů, které dokládají vytápění vnitřních prostor hradu pomocí kachlových kamen.

Hradní jádro chránila dvojice hradeb, mezi nimiž se nacházel zemní val s rondelem na severním konci. Vnitřní hradba (obr. 3: 2) byla vzdálená 14-17 m od paláce. Terén se svažoval od paláce a až v místech vnitřní hradby vytvářel nevelkou plošinu, která zároveň sloužila jako komunikace. Mocnost vnitřní hradby činila 1,65-1,8 m. Do severní části hradu umistoval V. Burian kovárnu (obr. 3: 3). Dále zde byla zjištěna 3,3 m široká proluka (obr. 3: 4), kterou můžeme považovat za bránu. Její ochranu zvyšoval také zemní val s rondelem, který byl v jednom místě přerušen, nejspíše průchodem (obr. 3: 5). Mezi valem a vnitřní hradbou se nacházel ještě příkop hluboký $4 \mathrm{~m}$. Vnější hradba dosahovala mocnosti 1,2 m (obr. 3: 6). Je pravděpodobné, že toto pásmo opevnění je mladší než vnitřní hradba a val ( $k$ tomu Plaček 2001, 640). Doplňovala ji na východní straně dovnitř otevřená pětiboká bašta či věž, jejíž břit směřoval k předhradí. Celkové rozměry dosahovaly $6,6 \times 6,15 \mathrm{~m}$, vnitřní prostor měl velikost 3,2 × 2,8 m (obr. 3: 7). V prostoru mezi jednotlivými hradbami nebyla podle V. Buriana zjištěna žádná zástavba. Pouze v místě ohybu vnější hradby se podařilo odkrýt mazanicovou destrukci na ploše o velikosti $2 \times 0,8 \mathrm{~m}$, kterou vedoucí výzkumu interpretoval jako pozůstatek pece (Burian 1972a, 8). Nelze však vyloučit, že mohlo jít o blíže neurčenou dřevohlinitou stavbu (Vránová, Vrána 2016, 44). Dále se poblíž paty valu směrem k vnitřní hradbě nalézala plošina se zvýšenou koncentrací podkov (dvě celé a 18 zlomků), což může indikovat polohu ohrady či stáje pro koně. Do hradního areálu se vstupovalo branou na severní straně (obr. 3: 8). Terén za vnější hradbou strmě klesal a doplňoval jej 2 metry hluboký př́kop, který odděloval samotnou fortifikaci od zbytku ostrožny. Na př́stupové komunikaci se nacházelo zemní opevnění podkovovitého tvaru složené z velkých balvanů (obr. 3: 9), někdy označované jako balvanovitá bašta (k tomu Burian 1972a, 9; 1979a, 246-247; Vránová, Vrána 2016, 40-46), které může být zařazeno jak do pravěku, tak vrcholného středověku (Vránová, Vrána 2016, 46).

$\mathrm{Z}$ výše uvedeného popisu je zřejmé, že blíže neurčená část hradního jádra zanikla již před započetím archeologických výzkumů. K jeho možnému dispozičnímu řešení bylo vysloveno několik hypotéz, které se opírají o výsledky výzkumu V. Buriana, a zejména o kolorovanou mapu z roku 1724 zachycující Tepenec od západu či severozápadu (obr. 4). Toto zobrazení pokládal V. Burian za nejvěrohodnější (1979a, 246). Badatelé T. Durdík

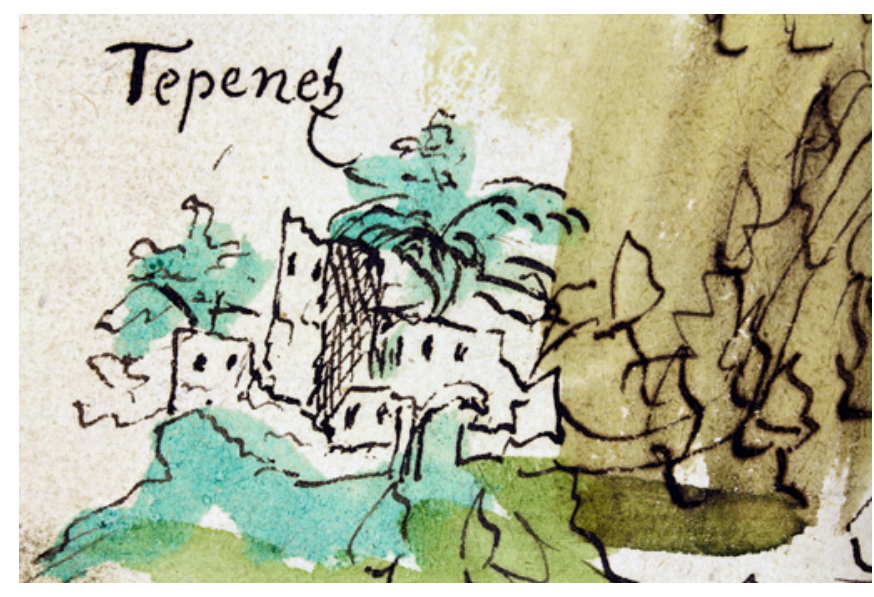

Obr. 4. Hrad Tepenec. Kresba hradu na mapě z roku 1724. Mapa uložena ve Státním okresním archivu Olomouc, fond Metropolitní kapitula Olomouc; sg. H Ia 1, kart. 421, f. 77

Fig. 4. Tepenec Castle. Drawing of the castle in a map from 1724. The map is deposited in the State District Archives Olomouc, Metropolitní kapitula Olomouc (Olomouc Metropolitan Chapter) fund; sg. H I a 1, box 421, f. 77.

a P. Bolina pokládali Tepenec za bezvěžový hrad s palácem snad ve tvaru písmene L (Durdík, Bolina 2001, 173). Naproti tomu lze v literatuře častěji dohledat názor M. Plačka. Podle něj je možné se domnívat, že v př́padě popisovaného hradu šlo „o dvoupalácové schéma s miniaturním mezilehlým dvorkem uprostřed, ale věžovitým palácem a menší budovou na jihovýchodě“ (Plaček 2001, 640).

Ve Státním okresním archivu Olomouc se podařilo ve fondu Ing. Josefa Kšíra ${ }^{7}$ dohledat čtyřri náčrty hradu Tepence, které s největší pravděpodobností pořídil právě J. Kšír. Podstatné jsou dva z nich, přičemž první skica (obr. 5) z roku 1952 byla nakreslena tužkou na papír, jen vyčnívající skály mají zelenou barvu. Kresba zachycuje tři pásma opevnění hradního jádra, přičemž v první linii lze rozeznat břit věže směřující $\mathrm{k}$ předhradí. Na severní straně byla autorem identifikována vstupní brána a šipkami vyznačeno předpokládané komunikační schéma. Bohužel možnou zástavbu v prostoru hradního jádra autor vyznačil velmi schematicky pomocí kruhů a oválů, které umístil do jihozápadního rohu a podél severovýchodní až severní strany. Připustíme-li, že kruh a dvojice oválů podél severovýchodní až severní strany jádra představují palácovou (?) stavbu částečně odkrytou V. Burianem, pak je možné usuzovat, že kruh nakreslený v jihozápadním rohu představuje již výzkumem nedotčený objekt. Snad by mohlo jít o věž zachycenou na mapě z roku 1724 (srov. obr. 4). Druhý nákres pochází z roku 1965 (obr. 6). Je na něm dokumentováno jádro hradu i celé předhradí až k vrcholu kopce Koruna (564 m n. m.). Předhradí, včetně šíjového příkopu, vymezuje červená čára. Zelená barva znázorňuje původní turistickou „zelenou“ trasu, která vedla předhradím. V místech za př́íkopem umístil autor ovál, který nejspíše označuje polohu nějakého blíže neurčeného objektu. Stojí za pozornost, že tato skica zachycuje polohu Johanina chrámku (viz níže). ${ }^{8}$

Podle nejstaršího nákresu publikovaného E. Prokischem (1941, obr. na str. 41) je možné předpokládat, že hradní jádro mělo původně téměř kosodélníkový tvar o maximálních rozměrech cca $40 \times 20 \mathrm{~m}$. Nákresy pořízené J. Kšírem zachycují tvar jádra už v podobě trojúhelníku o maximální velikosti cca $20 \times 25$ m (obr. 5), což nejspíše ukazuje na postupující těžbu blízkého kamenolomu. Neukončená vnitřní hradba pokračující severozápadním směrem naznačuje, že opevnění hradního jádra nejspíše pokračovalo dále na severozápad a centrální část hradu měla původně větší rozlohu. 


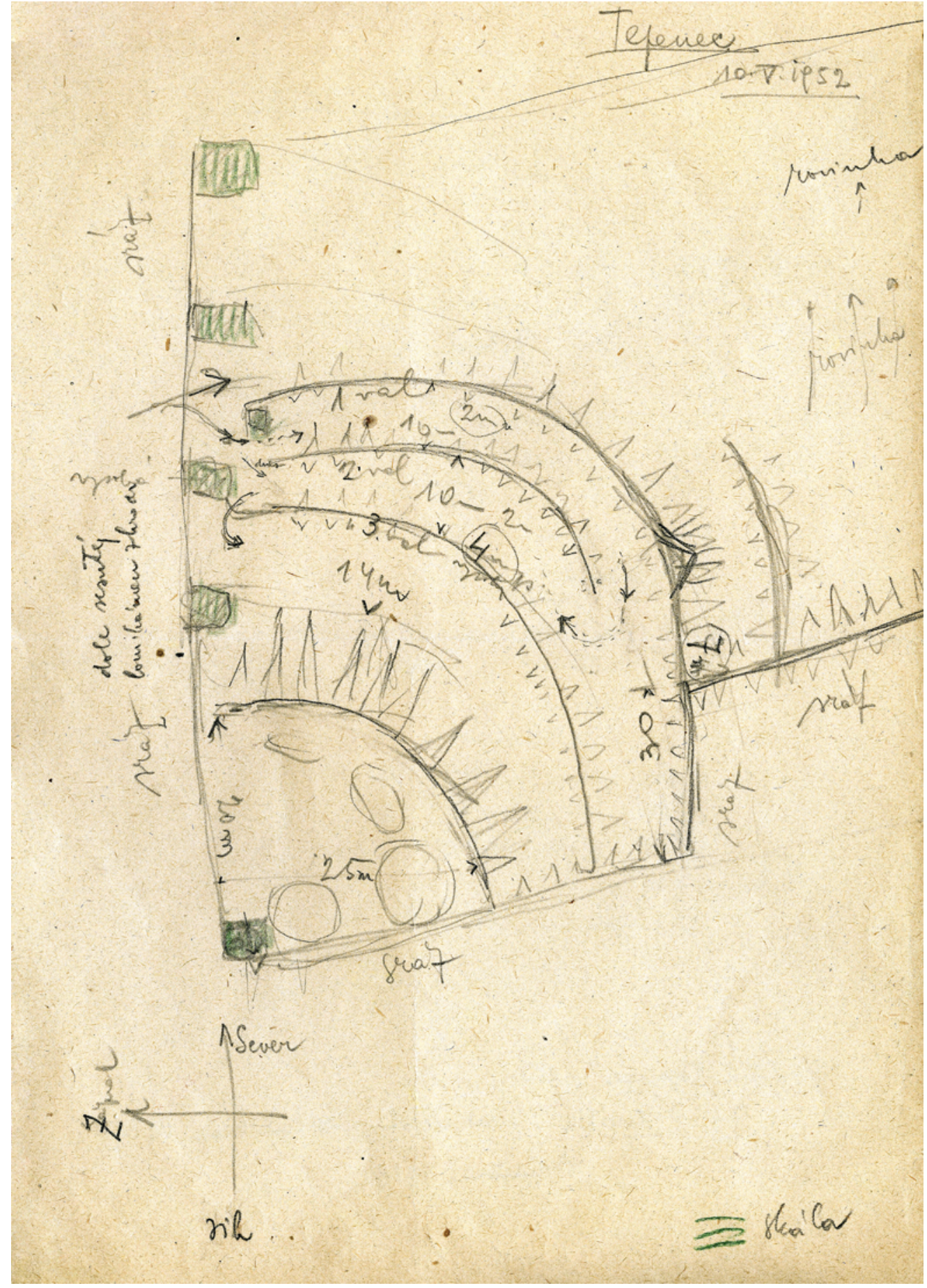

Obr. 5. Hrad Tepenec. Náčrt hradního jádra z roku 1952. Náčrt uložen ve Státním okresním archivu Olomouc, fond Josef Kšír, karton 33 inv. č. 349.

Fig. 5. Tepenec Castle. Drawing of the castle core from 1952. The drawing is deposited in the State District Archives Olomouc, Josef Kšír fund box 33, Inv. No. 349.
Pokusíme-li se vyjádřit k možné podobě hradu Tepence, pak je nutné vzít v potaz vyobrazení hradu na mapě z roku 1724 (obr. 4). Zdá se vysoce pravděpodobné, že se u západního okraje jádra tyčila vysoká hranolová věž a za ní stála př́ičně orientovaná palácová stavba. Je možné se domnívat, že torzo zdiva o síle 3,3 m na jižní straně jádra by mohlo souviset $\mathrm{s}$ hranolovou věží vyobrazenou na mapě z roku 1724. Snad ji můžeme spojovat s jedním z J. Kšírem oválně zakreslených objektů na jižní straně (obr. 5). Pokud je tato premisa správná, pak můžeme konstatovat, že uváděnou podobnost mezi hrady Tepencem, Kašperkem a Radyní (např. Tymonová 2002, 219) lze spatřovat pouze v dispozičním řešení palácové stavby. Avšak v př́ípadě Tepence je tato analogie spíše hypotetická, nebot tato budova nikdy nebyla prozkoumána v úplnosti a zbylá část hradního jádra se sesunula do údolí ještě před započetím záchranných výzkumů.
Předhradí referované lokality bylo opevněno valem pravěkého stáří, který vymezoval původní plochu hradiska (obr. 7). V jižní části se zde nacházela vstupní brána (obr. 7: 4), která umožňovala sestup do Bělkovického údolí. V těchto místech proběhl v roce 1997 výzkum, během kterého se podařilo zachytit koncentraci kůlových jamek. Snad mohla v těchto místech stát blíže neurčená konstrukce chránící bránu, která podle výsledků výzkumu zanikla požárem. Druhá brána do areálu pravěkého hradiska stála na jihovýchodě, poblíž šíjového př́ikopu. Tato část nebyla zatím zkoumána, a není proto možné ji dnes nějak více hodnotit (obr. 7: 5). Dodnes patrný vstup do prostoru předhradí se nachází na severovýchodní straně opevnění. Jde o bránu štěrbinového typu (obr. 7: 3; 8). Na ni navazovala kamenná hradba vedoucí západním směrem, která končila po $115 \mathrm{~m}$. Dále pokračoval pouze val vybudovaný v pozdní době bronzové až starší 


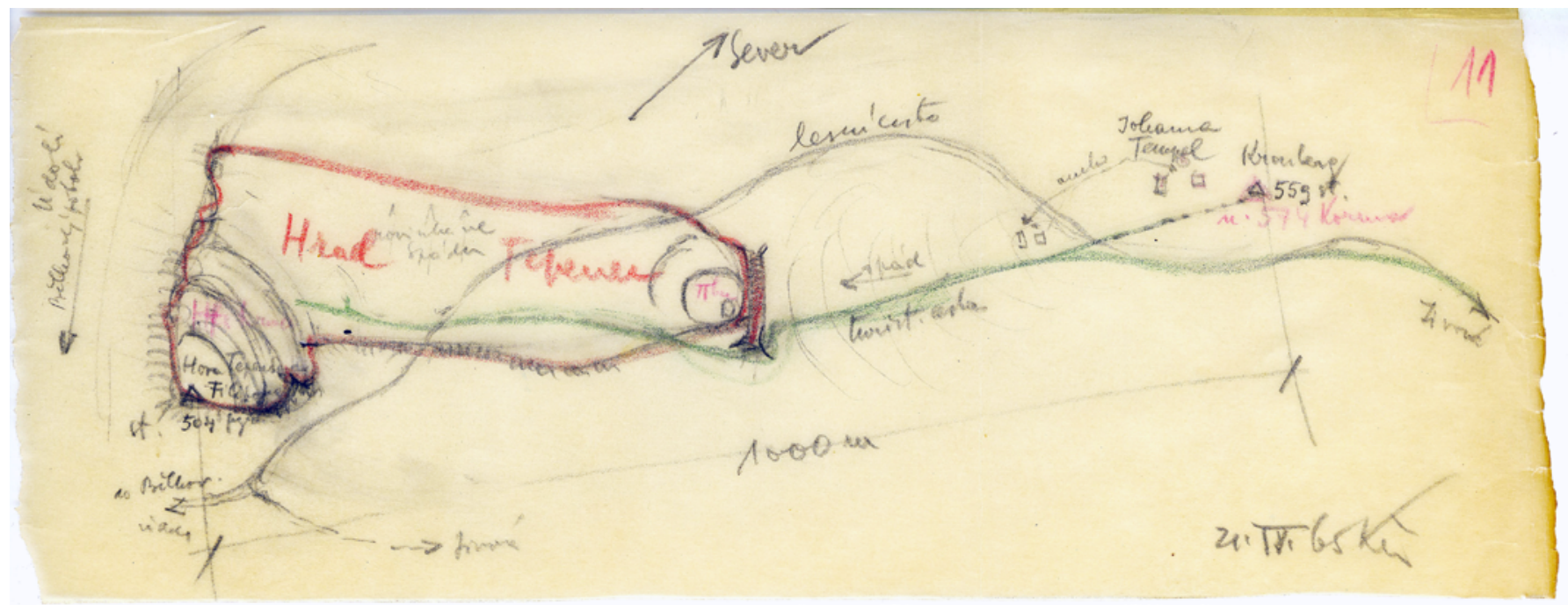

Obr. 6. Hrad Tepenec. Náčrt hradu z roku 1965. Náčrt uložen ve Státním okresním archivu Olomouc, fond Josef Kšír, karton 33 , inv. č. 349.

Fig. 6. Tepenec Castle. Drawing of the castle from 1965. The drawing is deposited in the State District Archives Olomouc, Josef Kšír fund, box 33, Inv. No. 349.

době železné. Zdá se pravděpodobné, že se během probíhajících markraběcích válek (1381-1404) obránci snažili dokončit kamenné hradby podél severní až severozápadní strany předhradí (srov. Tymonová 2002, 226). Na východní straně terén prudce stoupá až k vrcholu nad šíjovým př́ikopem. Podle provedené geofyzikální prospekce i terénního pozorování lze v těchto místech očekávat další zástavbu, pravděpodobně věž, která chránila vstup do prostoru předhradí (např. Vránová, Vrána 2016, 47-49; Tejkalová 2017, 21-29; Vágner, Milo 2020).

Na ploše předhradí se ještě před zahájením výzkumů rýsovaly prohlubně různých velikostí. Nejčastěji měly oválný či kruhový půdorys a byly interpretovány bud' jako cisterny na vodu, či těžební jámy, kde byl dobýván kámen na stavbu hradu (Burian 1970, 5; Dohnal 1980a, 11-12; Tymonová 2002, 221). Pozdější výzkumy doložily, že jde o pozůstatky různých objektů (např. zásobní jámy, kůlové jamky, zapuštěné části staveb) pravěkého i středověkého stáří (např. Tymonová, Kalábek 1999, 94). Zhruba uprostřed předhradí se podařilo prozkoumat studnu $\mathrm{s}$ vnitřní výdřevou. Během výzkumů bylo v areálu předhradí také zachyceno několik otevřených ohnišṫ. Nemalá část získaného archeologického materiálu pochází z kulturních vrstev, jejichž mocnost dosahovala od 10 do $55 \mathrm{~cm}$ (naposledy Vránová, Vrána 2016, 50-58; Vránová 2018, 247-248).

\section{Dějiny hradu Tepence}

První písemnou zmínku o hradu Tepenci nacházíme v kupní smlouvě uzavřené v Olomouci 29. června roku 1340, a to mezi moravským markrabětem Karlem a olomouckým biskupem Janem Volkem o prodeji pozemku u Bělkovic, který tehdy vlastnilo olomoucké biskupství. Text smlouvy se týká hory „Tepenecz“ a jejího bezprostředního okolí, kde zamýšlel Karel IV. vybudovat hrad s názvem „castri Twingenberg“ (např. CDM VII, 202-203, č. 279; Plaček 2000, 189). ${ }^{9}$ Ve smlouvě bylo užito sloveso decrevimus, jehož přesnější překlad je „nařídili jsme“ a nikoliv „nařizujeme“ (Vránová, Vrána 2016, 31). To znamená, že v době sepsání této listiny stavba hradu s největší pravděpodobností již probíhala. Avšak nemohlo se začít stavět dříve než roku 1334, kdy se Jan Volek ujal olomoucké diecéze a Karel se stal moravským markrabětem. V kupní smlouvě je uvedeno, že kdyby někdo v sousedství zamýšlel zř́ídit trh a mýtnou stanici, pak by na lidech olomouckého biskupa nemohl tepenecký purkrabí uplatňovat své pravomoci. Hlavním úkolem hradu měla být ochrana
Jívovské cesty (např. Bolina 2004a, 169; Vránová, Vrána 2016, 31). Svazky úvozových cest byly identifikovány východně od hradu (k tomu Bolina 2004a, 171-174; Martínek, Vránová 2018, 114, obr. 1), popřípadě v okolí kartuziánského kláštera v Dolanech, kde se předpokládá počátek této cesty přes Nízký Jeseník směrem do Slezska (Dehnerová, Šlézar 2015, 78).

Ve třetí závěti moravského markraběte Jana Jindřicha z roku 1371 (CDM X, 137-142, č. 118) je uveden hrad se vsí Jívovou. Toto zboží měl získat prostřední markraběcí syn Jan Soběslav, který nedlouho poté umírá. Nerovnoměrné rozdělení dědictví markraběte Jana Jindřicha mezi jeho dva zbývající syny stálo na počátku tzv. markraběcích válek (1381-1404), které probíhaly mezi nejstarším synem Joštem a nejmladším Prokopem (např. Mezník 2001, 223-224, 254-263, 270-284). Hned v první etapě konfliktu byl hrad Tepenec přepaden Prokopovými stoupenci, kteří jej značně poškodili. Po ukončení bojů připadl Tepenec markraběti Prokopovi, který zde ustavil Jindřicha z Nevojic za svého purkrabího. Jindřich z Nevojic stanul v čele bojové družiny složené z vlastních lidí i obyvatel blízké vsi Jívové. ${ }^{10}$ Měli na svědomí opakované drancování statků olomoucké kapituly, násilí na jejich obyvatelích a loupeže na silnicích. V roce 1400 se na Joštovu stranu přidal uherský král Zikmund Lucemburský a vyslal na ochranu statků olomoucké kapituly své vojsko vedené hejtmanem Jakubem Štěnětem z Bělin. Jedním z jeho cílů bylo hrad Tepenec dobýt, nebot̉ odtud Jindřich z Nevojic působil olomouckému biskupství značné škody. Zdá se velmi pravděpodobné, že nedlouho po roce 1400 byl Tepenec obležen a pobořen (Vránová, Vrána 2016, 31-33).

Na počátku 15. století se hrad v listinách objevuje již jen jako orientační bod. Roku 1405 daruje markrabě Jošt Tepenec i s okolním majetkem kartuziánskému klášteru v Dolanech. Zápis v zemských deskách z 9. ledna 1406 uvádí hrad jako pobořený (Burian 1979a, 246; Tymonová 2002, 226). Kartuziáni vlastnili pozemky i se zř́iceninou až do roku 1782, kdy byl jejich řád zrušen císařem Josefem II. Majetek od Náboženského fondu odkoupil roku 1825 hrabě Filip Ludvík S. Genois d'Harnoncourt, který nechal v areálu paláce postavit jehlancový památník. Nalezneme jej na mapě stabilního katastru z roku 1834 označený jako „Philips Pyramide“. Asi $600 \mathrm{~m}$ od něj dal ještě vybudovat na počest své manželky Johanin kruhový chrám (Johanen Tempel). Ani jedna z těchto staveb nebyla při výzkumech jednoznačně identifikována (např. Burian 1970, 5). 


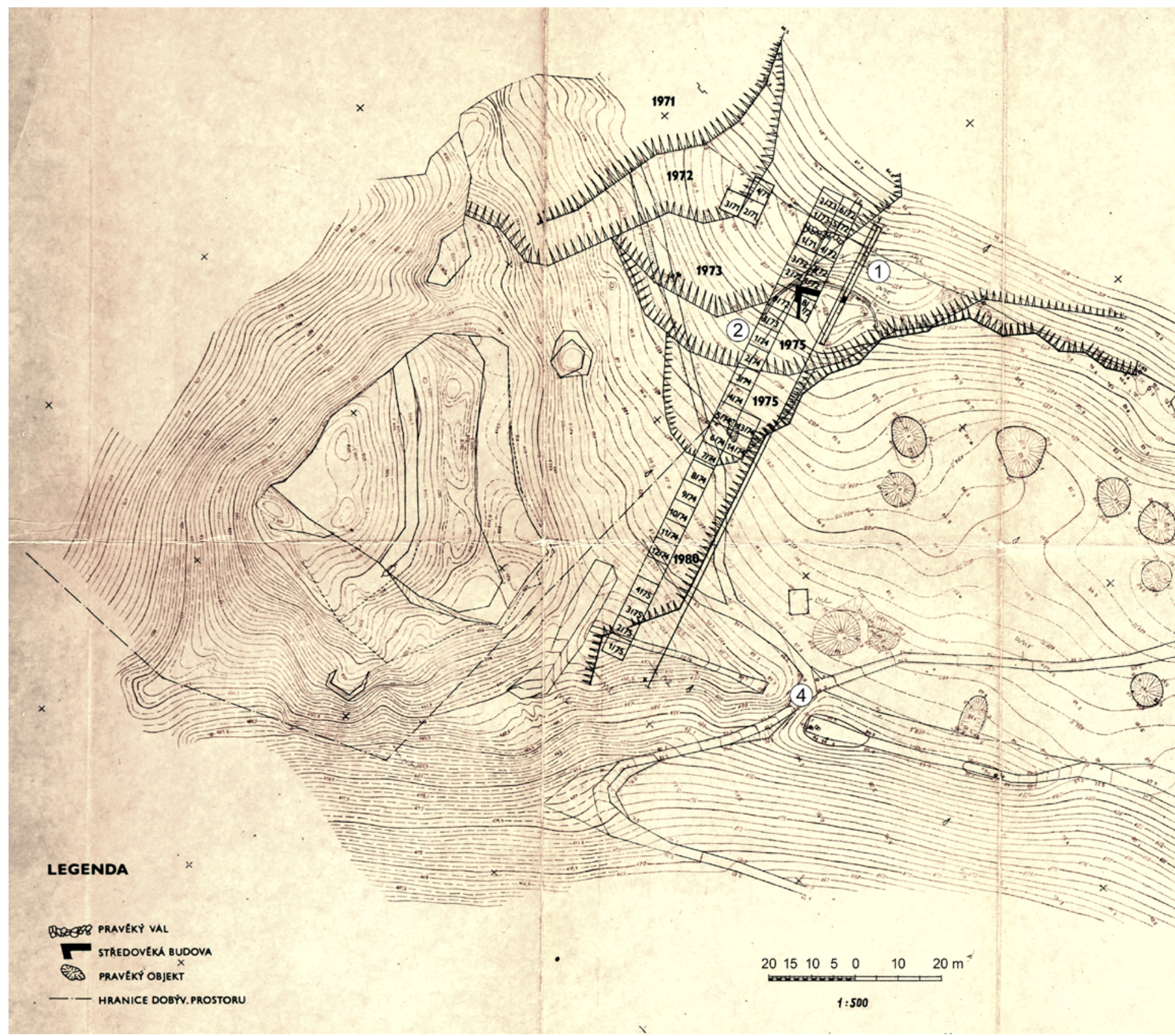

Obr. 7. Hrad Tepenec. Celkový plán výzkumů v letech 1971-1975 s vyznačením jednotlivých čtverců a informativní sondy. 1 - Informativní sonda; 2 - hlavní sonda; 3 - brána; 4 - brána na jižní straně; 5 - brána na jihovýchodní straně. Podle Dohnal 1980b, plán 1.

Fig. 7. Tepenec Castle. Overall plan of excavations in 1971-1975, marking the individual square units and informative test pits. 1 - Informative test pit; 2 - main trench; 3 - gate; 4 - south gate; 5 - southeast gate. After Dohnal 1980b, plan 1.

\section{Současný stav zpracování archeologických nálezů z lokality}

V literatuře z konce 19. a počátku 20. století nacházíme velmi obecný popis nálezů různých zbraní a nářadí pocházejících z lokality. Výslovně je však uvedena jen silná dýka a bronzový řetěz (např. Šindler 1927-1928, 9). Pouze V. Pinkava se ve své monografii o hradech zmiňuje o nálezu meče (Pinkava 1927, 12). Roku 1890 do dnešního Vlastivědného muzea v Olomouci věnoval učitel Vincenc Soldán železnou ostruhu, která pochází odněkud z prostoru Bělkovického lesa. Zda byla získána v blízkém okolí hradu, či nikoliv, nevíme (např. Burian 1970, 5). Další nález představuje bronzová jehlice z katastru Bělkovic, avšak její spojitost s referovanou lokalitou není zřejmá. Spíše může pocházet z nějakého zničeného hrobu, popř́ípadě z depotu (např. Dohnal 1972, 64). Krátkou zmínku o blíže nepopsaných zbraních odevzdaných do olomouckého muzea uvedl J. Šindler (Šindler 1927-1928, 9).

Úplně první výzkum v areálu hradu proběhl v roce 1928 , ale o těchto výkopech víme jen tolik, že zde lidé hledali hradní sklepy (Vránová, Vrána 2016, 11). V roce 1941 publikoval E. Prokisch první náčrt hradu, a to včetně rozsáhlého předhradí (Prokisch 1941, obr. na str. 41; Plaček 2001, obr. 1242). Nejstarším známým nálezem, který lze jednoznačně spojovat s pravěkým hradiskem, je bronzová sekera s tulejkou a ouškem objevená v kamenolomu po odstřelu skalní stěny (Burian 1970, 3). Další terénní výzkum na hradě provedl šternberský archivář Zdeněk Flejberk spolu se členy archeologických kroužků ve Šternberku, Dolanech a Droždíně. Z jeho krátké zprávy (Flejberk 1965) 


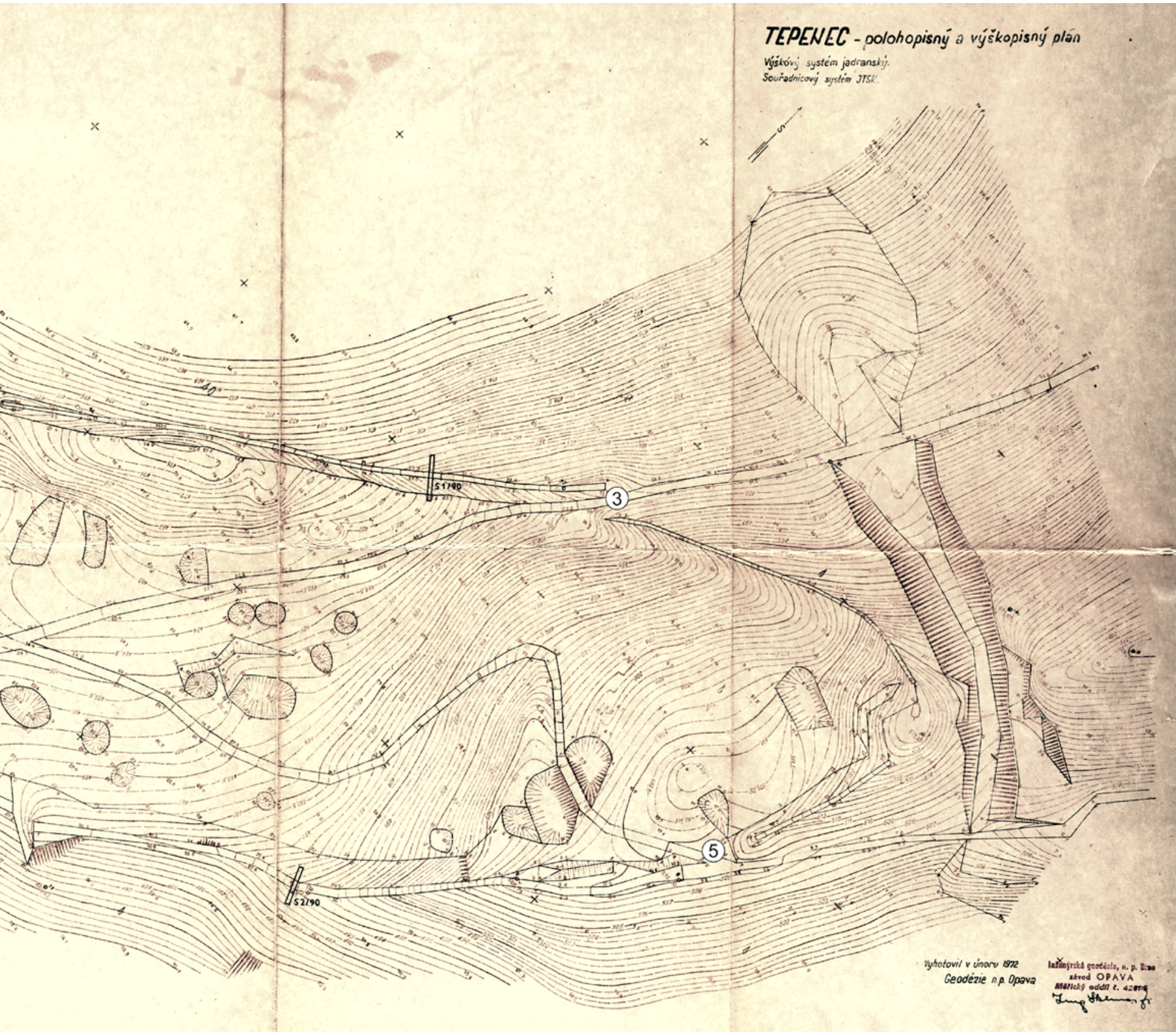

o tomto výzkumu plyne, že v prostoru jádra hradu byly vyhloubeny dvě sondy, přičemž prozkoumali dvě blíže nepopsané jámy. Za zmínku stojí nálezy kamenné nádoby a cínového prstenu s nápisem provedeným gotickou majuskulí CASPAR : MELCHIOR : BA(LTHASAR), o kterém se V. Burian domníval, že měl magický účel (Burian 1970, 5, 7). ${ }^{1}$

Od poloviny 60. let referovanou lokalitu ohrožuje blízký kamenolom, nebot značná část ostrožny byla označena za dobývací prostor. Ze schůze proběhlé ve dnech 30. a 31. března 1965 vyplynulo, že provozovatel lomu, těžící zde již od roku 1960, o existenci kulturní památky v dobývacím prostoru vůbec netušil. Na jednání v roce 1965 mu bylo dotčenými orgány památkové péče doporučeno, aby zažádal o vyjmutí kulturní památky z památkové ochrany s tím, že zde budou realizovány záchranné archeologické výzkumy předcházející postupující těžbě. V roce 1971 došlo z rozhodnutí Ministerstva kultury ČSR k vyškrtnutí podstatné části popisované lokality ze seznamu památkově chráněných objektů, což umožnilo pokračování těžby a postupnou likvidaci pravěkého hradiska a stř̌edověkého hradu. ${ }^{12}$

Záchranné archeologické výzkumy v areálu hradu započaly v roce 1968. V první etapě zkoumali hradní jádro V. Burian z Vlastivědného ústavu v Olomouci (dnes Vlastivědné muzeum v Olomouci) a B. Novotný z brněnské pobočky Archeologického ústavu ČSAV. Od roku 1969 provádělo výzkumy pouze olomoucké muzeum. Během let 1968-1971 se podařilo prozkoumat podstatnou část hradního jádra na samotném konci ostrožny (např. Burian 1970, 5-9; Novotný 1970, 63-64; Burian 1971a, 2-6; 1972a, 7-9). Od roku 1971 dodnes probíhá výzkum 
v areálu předhradí (Vránová, Vrána 2016, 47-58). Ojedinělé archeologické nálezy byly předávány do muzea postupně jak náhodnými nálezci, tak zaměstnanci muzea (např. Burian 1980, 112-113; 1981a, 53; Dohnal 1991, 2). V letech 1997-1999 se na výzkumu předhradí podílelo Vlastivědné muzeum v Olomouci spolu s Ústavem archeologické památkové péče v Olomouci (dnes Archeologické centrum Olomouc). Tato instituce provádí výzkumy na lokalitě dodnes. Celkem bylo prozkoumáno 275,5 čtverců o velikosti $5 \times 5 \mathrm{~m}$ a 13 sond odpovídající ploše $7535 \mathrm{~m}^{2}$.

Podle zpř́stupněných výsledků výzkumů provedených v prostoru hradního jádra i předhradí lze konstatovat, že lokalita byla osídlena v několika obdobích. Rámcově do neolitu, popřípadě eneolitu můžeme zařadit ojedinělé nálezy broušených kamenných nástrojů a několik kusů štípané industrie (např. Burian 1979a, 245; Tymonová, Kalábek 1999, 92; Procházková, Kalábek 2000, 168, obr. 1: 5, 6), avšak je nutné připustit, že jejich intepretace není dosud zcela jasná. V úvahu připadá možnost krátkodobého osídlení lokality, nebo druhotného využití těchto nástrojů ve středověku jako hromových klínů. ${ }^{13}$ Druhý horizont osídlení lze klást do pozdní doby bronzové až starší doby železné (stupně Reinecke HB-HC), kdy byla lokalita opevněna kamenohlinitým valem (k tomu Dohnal 1988, 40-41; Vránová, Vrána 2016, 27-28). Nečetné zlomky laténské keramiky vyzvednuté na předhradí naznačují nejspíše možnost přechodného využití ostrožny v mladší době železné (např. Martínek, Vránová 2018, 113). Opětovně byla lokalita osídlena ve 14. století, kdy zde nechal Karel IV. vybudovat hrad Tepenec, který na přelomu 14. a 15. století zanikl $\mathrm{v}$ důsledku válečných událostí (k nálezům např. Vránová, Vrána 2016, 59-64; Vránová 2018, 247-248). Nálezy raně novověké keramiky dokládají blíže neurčité sídelní aktivity během raného novověku, kdy zde byla obnovena původní středověká studna. V 19. století nechal hrabě d'Harnocourt v areálu hradu vybudovat jehlancový památník a Johanin chrámek (Tymonová, Kalábek 1999, 94; Vránová, Vrána 2013, 296-297).

Zpracování rozsáhlého nálezového fondu z hradu Tepence se nejprve ujal V. Burian, který vyhodnotil pouze vybrané skupiny artefaktů. Spolu s ostatními nálezy z dolanské kartouzy publikoval vyzvednuté kolekce ostruh, podkov, třmenů, kamenných projektilů, hřebíků, hřebel a kostěných artefaktů (Burian 1974, 18, obr. 1: 3; 1979b, 22-26; 1981b; 1982; 1984; 1985a; 1985b; 1988, 305-307, obr. 1: 2, 3, 5). Zveřejněny byly také výsledky rozboru uhlíků z výzkumu V. Buriana (Opravil 1980, 28). S velkým časovým odstupem zpracoval keramické nálezy z prostoru hradního jádra J. Rodina ve své nepublikované bakalářské práci (Rodina 2001). Z metalických nálezů nově vyhodnotil P. Žákovský fragmenty tesáků (Žákovský 2014, 171-173). ${ }^{14}$ Dosud zpřístupněné výsledky archeologických výzkumů na předhradí Tepence jsou o poznání skromnější. V podstatě je suplují krátké zprávy o proběhlých výzkumech (např. Dohnal 1974, 34-36, tab. 32-34; Tymonová, Kalábek 1999, 89-95; Procházková, Kalábek 2000, 167-168; Vránová 2014, 200-201; 2018, 247-248) a dvojice populárně naučných brožurek vydaných v řadě Archeologické památky střrední Moravy, svazek 9 a 21 (Vránová, Vrána 2005; 2016, zde uvedena další literatura).

Podrobné analýzy se zatím dočkal fortifikační systém předhradí (Tymonová 2002, 215-228), kolekce archeologických nálezů vyzvednutých ze studny (Vránová et al. 2010, 61-66; Vránová, Vrána 2013, 289-299), nalezená struska, která naznačuje provozování kovářského řemesla $\mathrm{v}$ prostoru předhradí (Vránová et al. 2014, 639-647), popřípadě dno skleněné číšky z výzkumu na předhradí (Sedláčková 2001, 442). V posledních letech J. a V. Vránovi publikovali olověné projektily z palných zbraní, ostruhy a podkovy (Vránová, Vrána 2008; 2012a; 2012b). Dále disponujeme předběžným popisem a interpretací odkrytých středověkých staveb. Zhruba dvacet prozkoumaných půdorysů objektů lze rozdělit na dva základní typy, a to nadzemní stavby a suterény zahloubené do podloží, přičemž několik z nich bylo opatřeno vstupní šíjí (srov. Tymonová, Kalábek 1999, 93-94; Procházková, Kalábek 2000, 167; Vránová, Vrána 2016, 50-58, obr. 29-31, 34; Vránová 2018, 247-248). Nelze vyloučit možnost, že se zde nacházelo opevněné podhradní městečko s volným prostranstvím uprostřed a zástavbou kolem něj (Doležel 2008, 488; Vránová, Vrána 2016, 63). ${ }^{15}$ Mezi poslední zveřejněné výsledky můžeme přiřadit provedení petroarcheologické analýzy pěti fragmentů středověké keramiky z výzkumu na předhradí v roce 2008 (Gruntová 2015) či realizaci geofyzikální prospekce v nejvyšším místě předhradí, hned za šíjovým př́íkopem (Tejkalová 2017; Vágner, Milo 2020).

\section{Záchranný archeologický výzkum v letech 1971-1975}

Během výzkumu V. Buriana byly v místech styku hradního jádra s předhradím nalezeny pravěké střepy, které V. Burian zařadil do starší doby železné (Burian 1971a, 6; 1971b, 67). S ohledem na dokončování exkavace hradu bylo zřejmé, že další terénní práce budou prováděny $\mathrm{v}$ areálu předhradí. Vyzvednutá halštatská keramika dokládala pravěké osídlení v daném prostoru, a proto vedení dalších výzkumů V. Burian přenechal vedoucímu archeologického oddělení Vlastivědného ústavu v Olomouci V. Dohnalovi. Jím vedené terénní práce probíhaly během letních měsíců v letech 1971-1975. ${ }^{16}$ Původní záměr prozkoumat celou ohroženou plochu předhradí byl pozměněn vzhledem k jeho značné rozloze.

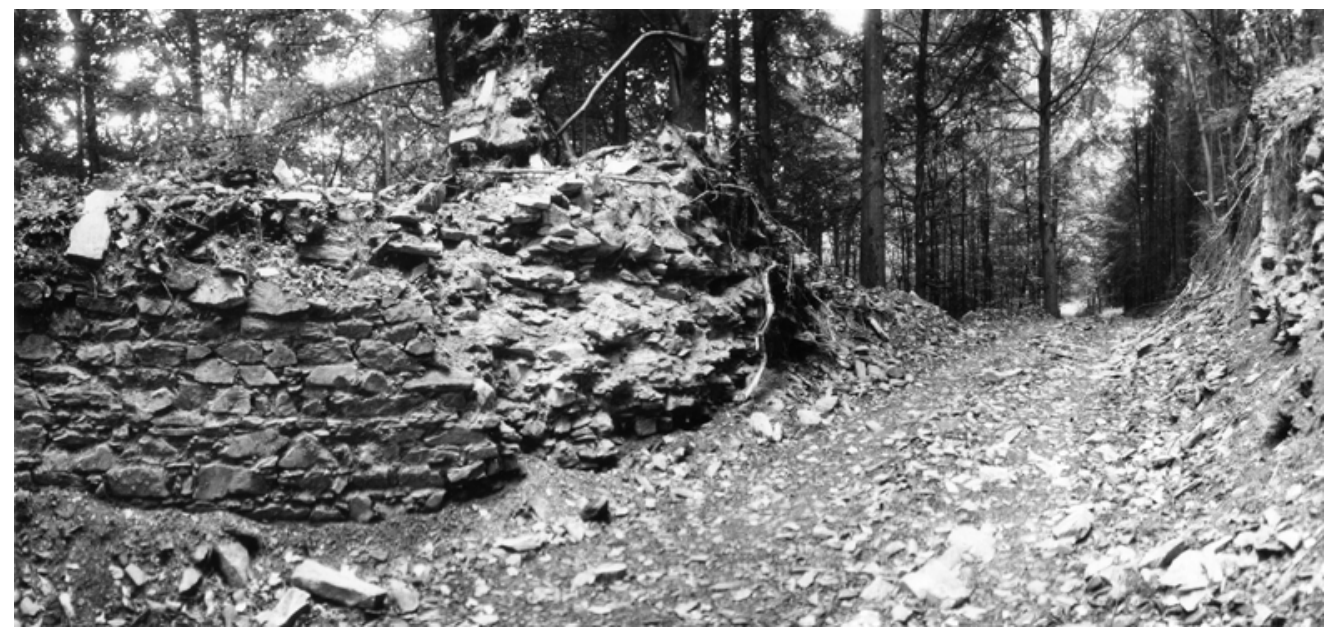

Obr. 8. Hrad Tepenec. Odkrytá brána do areálu předhradí. Podle Dohnal 1980c, foto č. 18.

Fig. 8. Tepenec Castle. Excavated gate to the outer bailey area. After Dohnal 1980c, photo No. 18. 
Tepenec čtverec $1 / 72$
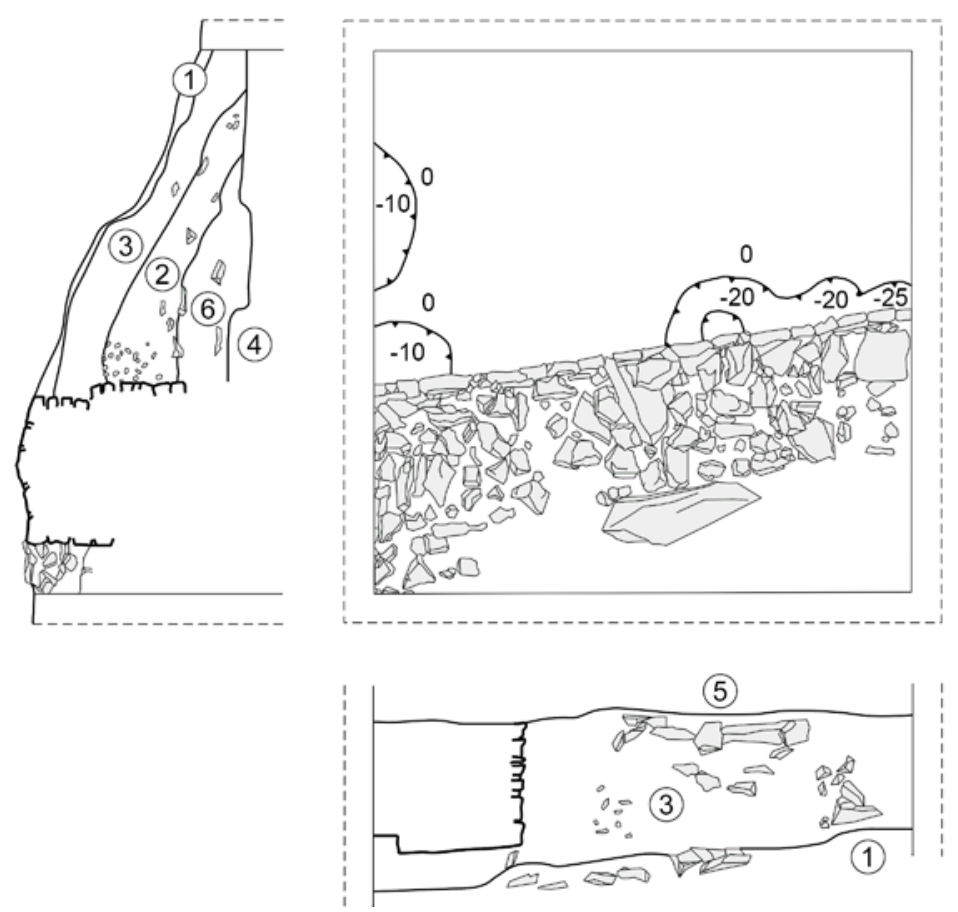

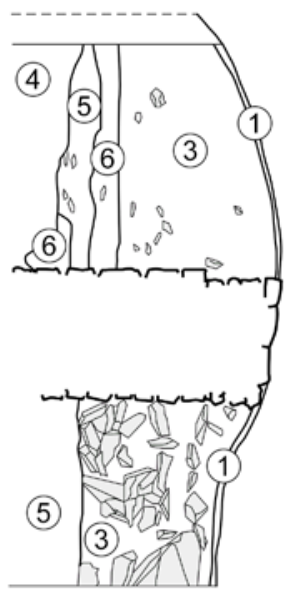

Obr. 9. Hrad Tepenec. Sondou zachycené nároží zdí objektu č. 1/72 ve čtverci 1/72. 1 - povrchová (humusová) vrstva; 2 - světle hnědá hlína; 3 - žlutošedá hlína; 4 - žlutá jílovitá zemina bez nálezů; 5 - žlutá jílovitá zemina se štěrkem bez nálezů; 6 - tmavší hnědá hlína s nálezy (výplň objektů, kulturní vrstva). Podle Dohnal 1980b, plán 14 Digitalizace V. Tomka.

Fig. 9. Tepenec Castle. Corner of the walls of Structure No. 1/72 in square unit $1 / 72$, detected by a test pit. 1 - Surface (humus) layer; 2 - light brown clay; 3 - yellow-grey clay; 4 -yellow clayey soil without findings; 5 -yellow clayey soil with gravel without findings; 6 - darker brown clay with findings (features' fill, cultural layer). After Dohnal 1980b, plan 14. Digitized by V. Tomka.
Po dohodě s vedením kamenolomu přistoupil V. Dohnal k provedení zjištovací sondy, která protala celý opevněný areál od SZ $\mathrm{k} J V$ a skládala se ze čtverců o velikost $5 \times 5 \mathrm{~m}$. Podle předpokladu měla sonda dosahovat celkové délky $110 \mathrm{~m}$, šíre $5 \mathrm{~m} \mathrm{~s}$ tím, že v místech opevnění byla její šířka dvojnásobná (Dohnal 1974, 35).

V roce 1971 započal výzkum položením tzv. informativní sondy č. I (30 m dlouhá a $1 \mathrm{~m}$ široká) nad západním svahem (obr. 7: 1) a založením čtyř čtverců (označené č. 1/71-4/71) s tím, že čtverec $1 / 71$ se stal základem po hlavní zjištovací sondu (obr. 7: 2). V roce 1972 otevřel V. Dohnal čtverců devět (1/72-9/72) a v roce 1973 pak další tři (1/73-3/73). Výzkum se v roce 1974 přesunul na plochu předhradí, kde byla hlavní sonda prodloužena o $60 \mathrm{~m}$ (čtverce 1/74-12/74). Z důvodu výskytu pravěkých objektů byla sonda rozšíŕena o dva čtverce severním směrem (13/74-14/74). V poslední sezóně byly založeny čtyři čtverce $(1 / 75-4 / 75),{ }^{17}$ které vedly skrz val na jižní straně předhradí. ${ }^{18}$ Během zimy 1974/1975 projel po lesní cestě do prostoru předhradí buldozer a poničil zde vstupní bránu na severovýchodní straně. Po odstranění nánosů zeminy se podařilo po obou stranách odhalit kamenné zdi (obr. 7: 3; 8), které lze spojovat se zdivem středověké brány (Dohnal 1977, 21-22).

Terénní práce v letech 1971-1975 probíhaly ručním skrýváním zeminy po přibližně $20 \mathrm{~cm}$ vrstvách až na podloží tvořené jílem nebo navětralou skálou. Ze stratigrafického hlediska šlo o poměrně jednoduchá souvrství (obr. 9, západní profil). Pod drnem se nacházela šedohnědá humusová vrstva s drobným kamením. Pod ní ležela světlehnědá hlína s kameny, která plynule přecházela do žlutohnědé hlinité vrstvy a ta do podloží. Jak ze světlehnědé hlíny, tak ze spodnější žlutohnědé pocházejí pravěké i stř̌edověké nálezy. Lze se ztotožnit s názorem V. Dohnala, že níže položenou žlutohnědou vrstvu můžeme spojovat s dobou fungování pravěkého hradiska a světlehnědou vrstvu považovat za mladší středověký horizont osídlení (Dohnal 1980a, 13-17).
Z výsledků výzkumu lze zmínit zejména doložení pravěkého opevnění lokality v podobě kamenohlinitého valu o šíŕce asi $3 \mathrm{~m}$, který sonda protala jak na severozápadním, tak jihovýchodním okraji ostrožny. Za valem na severní straně byla zjištěna 3-4 m hluboká př́íkopová prohlubeň vzniklá nejspíše získáváním hlíny na jeho výstavbu (např. Dohnal 1972, 63; 1974, 35). V areálu hradiska zachytil V. Dohnal celkem čtyři pravěké sídlištní objekty (např. Dohnal 1988, 41). Val byl nepochybně využit jako fortifikační prvek i ve vrcholném středověku. Podle výzkumů z let 1997-1999 jej postupně nahrazovala kamenná hradba, kterou však obránci nestihli na severní straně dokončit (Tymonová 2002, 226).

I když hlavním zájmem V. Dohnala bylo pravěké osídlení lokality, podařilo se mu získat několik nových poznatků o užívání předhradí ve středověku. Kromě nečetných nálezů vyzvednutých z kulturních vrstev a odkryté středověké brány do prostoru předhradí jde zejména o dva částečně prozkoumané objekty. Už tzv. informativní sonda narazila na kamennou zed' prvního objektu (dále jen obj. č. 1/72). Nároží tohoto objektu zachytila hlavní sonda ve čtvercích 1/72, 2/72 a 8/72. Severozápadní zed’ o výšce $148 \mathrm{~cm}$ byla postavená z kamene spojovaného jílem o síle $110 \mathrm{~cm}$ u koruny zdiva a $120 \mathrm{~cm}$ u základu stěny. Druhá měla částečně rozebraný vnější líc, proto vypadala jako výrazně tenčí. Sonda protala pouze jihozápadní nároží, kde obě zdi svíraly úhel $75^{\circ}$. Delší osou byl objekt orientován ve směru SV-JZ. Zdi objektu spočívaly na předem připraveném terénu a podle popisu V. Dohnala jej proti sesunutí zajištoval násyp jílovité zeminy se štěrkem (obr. 9-12). Tuto úpravu lze vidět zejména na jihozápadním profilu čtverce 1/72 (obr. 9). Podobné zajištění stavby pomocí výsypky uváděla V. Vránová v př́ípadě domu s kamennými stěnami, prozkoumaném na předhradí Tepence $\mathrm{v}$ roce 2020 (Vránová 2021, 239-240). Podle V. Dohnala měla být jím odkrytá budova podsklepena, byt' stopy podlahy se nepodařilo rozpoznat. 

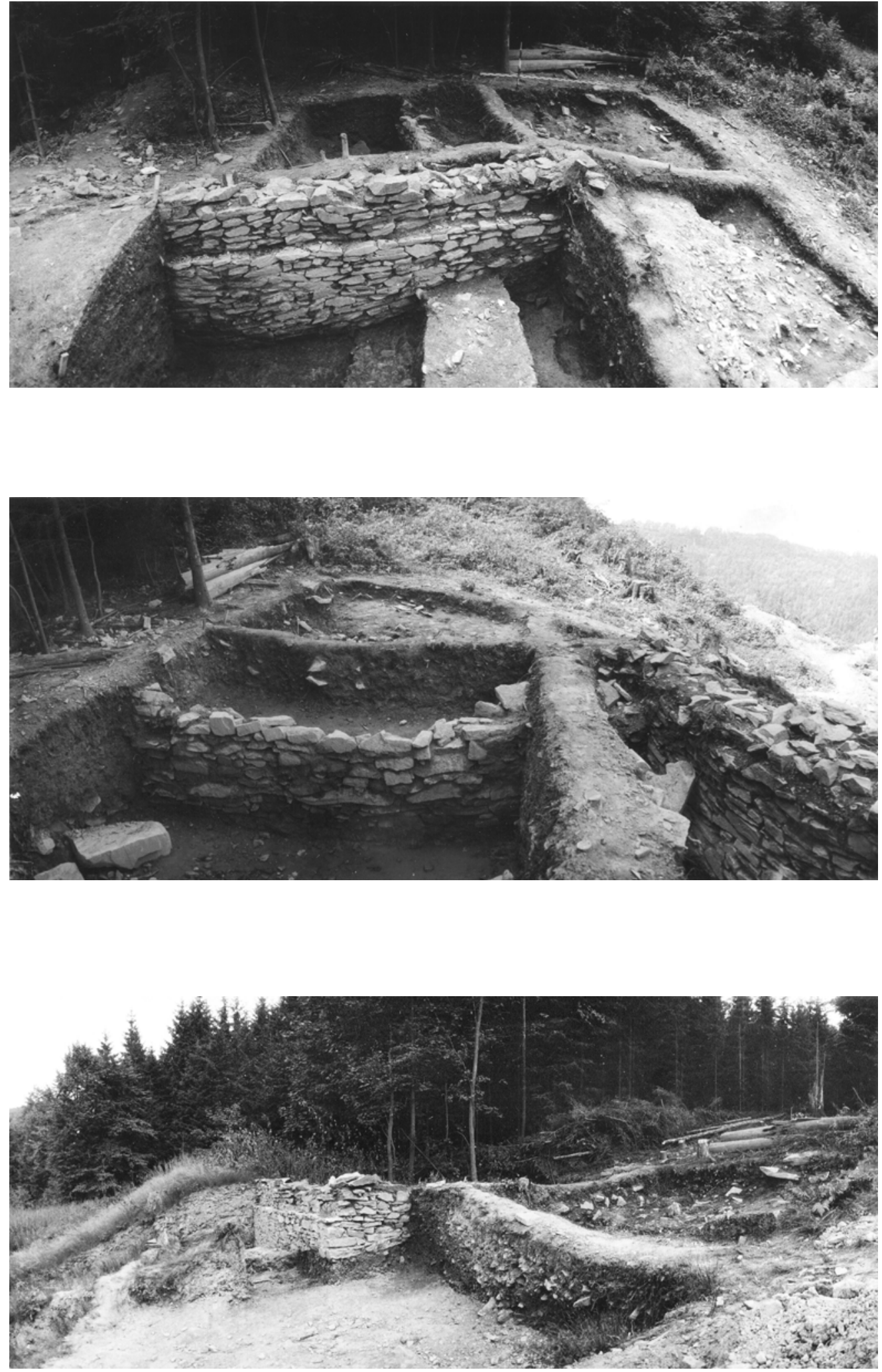

Obr. 10. Hrad Tepenec. Fotografie nároží zdí objektu č. 1/72 ve čtverci 1/72. Podle Dohnal 1980c, foto č. 52.

Fig. 10. Tepenec Castle. Photograph of the corner of the walls of Structure No. $1 / 72$ in square unit $1 / 72$. After Dohnal 1980c, photo No. 52.
Obr. 11. Hrad Tepenec. Fotografie čtverce $8 / 72$ se zachyceným nárožím objektu č. 1/72. Podle Dohnal 1980c, foto č. 67.

Fig. 11. Tepenec Castle. Photograph of square unit $8 / 72$ with the detected corner of Structure No. 1/72. After Dohnal 1980c, photo No. 67.
Z objektu byla vyzvednuta keramika a železný závěs dveří. Vedoucí výzkumu odhadl celkové rozměry zachyceného objektu na $20 \times 10 \mathrm{~m}$. V. Dohnal tuto stavbu interpretoval jako hospodáŕskou či skladovací budovu (Dohnal 1974, 35; 1980a, 20-22).

Druhý částečně prozkoumaný objekt (dále jen obj. č. 1/74) stál asi o $50 \mathrm{~m}$ dále ve čtvercích 10/74, 11/74 a 12/74. Jeho půdorys indikovala tmavší hlína, která se odlišovala od okolní žlutohnědé hlíny. Objekt měl nejspíše kvadratický půdorys s delší osou směřující k SZ-JV. Měřitelné rozměry činily přibližně
$9 \times 2,5 \mathrm{~m}$ (obr. 13). Nepodařilo se ale zjistit žádné stopy po konstrukci stěn, pouze v okolí objektu se vyskytovalo větší množství kamenů různých velikostí, které mohly se stavbou souviset, např́íklad jako podezdívka. ${ }^{19}$ Podle V. Dohnala šlo o částečně prozkoumanou nadzemní stavbu lehké konstrukce, snad srub, či nějakou kůlnu s hospodářskou funkcí (Dohnal 1980a, 26-27, 43-44). Z okolí tohoto objektu pochází větší množství hřebíků, malá železná skoba/svorka, hrot šípu a početná kolekce keramických nálezů. 

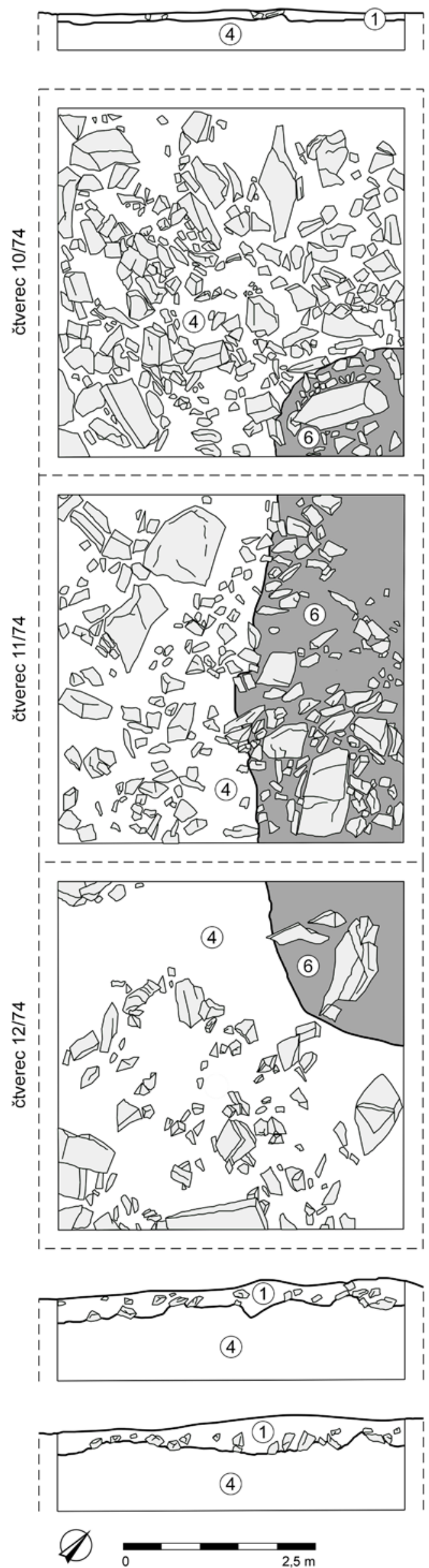

\section{Středověké objekty prozkoumané v letech 1971-1975}

Objev dvou stř̌edověkých objektů během výzkumu v letech 1971-1975 poprvé doložil, že areál pravěkého hradiska byl opětovně využit k osídlení ve 14. století. Dosavadní názory o funkci objektů jako cisteren či míst pro těžbu kamene na stavbu hradu bylo nutné přehodnotit (srov. Tymonová, Kalábek 1999, 93-94; Tymonová 2002, 221; Vránová, Vrána 2005, 31-34, 38). S přibývajícími výzkumy v prostoru předhradí počet staveb řazených do stř̌edověku stále narůstal a dnes jsou jich známy na dvě desítky (např. Vránová, Vrána 2016, 50-58).

Na základě dokumentace pořízené během výzkumu v letech 1971-1975 můžeme oba prozkoumané objekty pokládat za nadzemní (Dohnal 1980a, 43-44). Je však třeba litovat faktu, že ani jeden nebyl prozkoumán v úplnosti, což snižuje možnost jejich bližšího poznání a následnou interpretaci. Nejprve se zaměříme na obj. č. 1/74 identifikovaný ve čtvercích 10/74, 11/74 a 12/74. V. Dohnal tuto stavbu považoval za srub či kủlnu s tím, že podle dochovaných plánů nejspíše nestál na kamenné podezdívce (obr. 13). Stěny podle všeho nebyly omazány hlínou, nebot mezi nálezy je mazanice zastoupena pouze ojedinělými amorfními kusy, bez jakýchkoliv otisků po konstrukčních prvcích na povrchu. S možnými nadzemními partiemi stavby můžeme spojovat vyzvednutá rozličná stavební kování (hřebíky, popř. skobu/ svorku). Kolekce keramických nálezů pocházející z objektu a jeho nejbližšího okolí (okraje hrnců, výlevka konvice, zlomek okraje mísy, zlomky dvou kahanů) indikují jeho možné obytné využití.

V areálu předhradí Tepence evidujeme několik dalších podobných nadzemních budov. Jiná stavba byla prozkoumána v roce 1997. Nejspíš stála na kupovitých kumulacích kamenů a v jejich blízkosti se nacházelo větší množství hřebíků, kování závěsu dveří, visací zámek a klíc. Také v tomto případě M. Tymonová s M. Kalábkem připouštěli, že by mohlo jít o budovu srubového typu. Ta podle nálezu předběžně určeného stříbrného českého feniku z let 1392-1393 nejspíše zanikla na počátku 15. století. Blízko této stavby byly zjištěny dvě kamenné stěny, představující nejspíše další nadzemní objekt, a západně od něj se nacházel relikt základů ohniště nebo pece (Kalábek, Tymonová 1998, 8-9; Tymonová, Kalábek 1999, 92; Tymonová 2002, 221).

$\mathrm{V}$ roce 2007 se podařilo prozkoumat kamennou podezdívku stavby, která měla téměř čtvercový půdorys. Vnitřní rozměry dosahovaly velikosti 2,14 × 2,2 m. Podezdívka se skládala z lomového kamene spojovaného jílem (Vránová, Vrána 2016, 52, obr. 30). Jižně od tohoto půdorysu se nacházel zahloubený suterén, který mohl s výše uvedenou nadzemní stavbou souviset. Jiný typ konstrukce stěn mohl mít předpokládaný nadzemní objekt prozkoumaný v roce 2008, který se skládal z reliktu zdi, dvou kůlových jamek a sídlištního objektu (Vránová, Vrána 2016, 52).

Zdá se vysoce pravděpodobné, že v kontextu osídlení na předhradí Tepence nadzemní stavba (obj. č. 1/74) zachycená v roce 1974 ve čtvercích 10/74-12/74 nijak zvlášt nevybočuje z běžného standardu, i když výše uvedené příklady jsou značně různorodé a z velké části byly publikovány jen předběžně. Různé analogie lze najít i na dalších středomoravských lokalitách. Např́íklad při

Obr. 13. Hrad Tepenec. Odkrytý půdorys objektu ve čtverci 10/74, 11/74 a 12/74 1 - povrchová (humusová) vrstva; 2 - světle hnědá hlína; 3 - žlutošedá hlína; 4 - žlutá jílovitá zemina bez nálezů; 5 - žlutá jílovitá zemina se štěrkem bez nálezů: 6 - tmavší hnědá hlína s nálezy (výplň objektư, kulturní vrstva). Podle Dohnal 1980b, plán 25-27. Digitalizace V. Tomka.

Fig. 13. Tepenec Castle. Excavated layout of features in square units 10/74, 11/74 and 12/74. 1 - Surface (humus) layer; 2 - light brown clay; 3 - yellow-grey clay; 4 - yellow clayey soil without findings; 5 - yellow clayey soil with gravel without findings; 6 - darker brown clay with findings (features' fill, cultural layer). After Dohnal 1980b, plan 25-27. Digitized by V. Tomka. 
výzkumu ve městě Litovli byla částečně prozkoumána kamenná podezdívka, kterou P. Šlézar spojoval s měštanským domem hrázděné konstrukce. Na základě rozboru keramiky stavbu klade do třetí čtvrtiny 13. století (Šlézar 2008, 172-175, obr. 10-12). Další př́ílady známe z areálu města Olomouce, odkud J. Bláha publikoval několik nadzemních domů rozličných konstrukcí. Dle jeho závěrů je většina z nich datována do druhé poloviny 13., popřípadě až do průběhu 14. století (srov. Bláha 1999, 209-210; Procházka 2007, 54-55). Z Olomoucka můžeme ještě připomenout objekt z intravilánu Dolan, který měl stěny z pěchované hlíny a byl datován do 14.-15. století. (Trňáčková 1963, 17; Kalábek 2005, 58, 62-63). Lze také upozornit na prozkoumanou stavbu (struktura č. 929) z Litomyšle, která měla stěny vybudované technikou roubení a podle dendrochronologické analýzy bylo dřevo smýceno v letech 1301-1302 (srov. Vích 2015, 208-221, obr. 4-6).

Druhý V. Dohnalem prozkoumaný objekt s kamennými stěnami spojovanými jílem (obj. č. 1/72) interpretoval vedoucí výzkumu jako hospodářskou či skladovací budovu, její celkové rozměry odhadl na $20 \times 10 \mathrm{~m}$. Dnes s tímto výkladem můžeme těžko více polemizovat. Půdorys stavby nebyl odkryt v úplnosti a kolekce vyzvednutých nálezů neposkytuje žádné další indicie k jiným možným výkladům. Pouze lze podotknout, že objektů $\mathrm{s}$ kamennými stěnami známe $\mathrm{z}$ tepeneckého předhradí výrazně méně než staveb dřevohlinité konstrukce. V areálu předhradí máme doloženo několik podobných nadzemních objektů s kamennými stěnami, které byly zároveň podsklepené (Vránová, Vrána 2016, 52-53).

Např́íklad v roce 2012 prozkoumala V. Vránová dva suterény nadzemních staveb částečně zasekané do rostlé skály. Hloubka obou objektů činila 1,2 a 1,3 m. Jeden z nich byl opatřen vstupní šíjí. Ve druhém případě se podařilo doložit otopné zařízení, čímž lze připustit tedy jinou než pouze skladovací funkci (srov. Vránová, Vrána 2016, 53). Poměrně rozsáhlý půdorys zahloubeného nadzemního objektu byl částečně prozkoumán v roce 2017. Na rozdíl od všech ostatních staveb s kamennými zdmi má tato budova kameny spojované maltou. Z blízkosti objektu pochází kamenný článek s prohlubní uprostřed, který náleží ke konstrukci dveř́i (Vránová 2018, 247-248).

V prostoru střední Moravy najdeme blízké paralely k těmto objektům s kamennými stěnami např́klad ve městě Olomouci (Bláha 1999, 203-206, 208, obr. 13: a; 14). Podle názoru P. Michny zde můžeme počítat s rozšírením kamenných staveb od přelomu 14. a 15. století (Michna 1982, 220-221; Procházka 2007, 56). Dodejme, že zahloubené části nadzemní stavby s kamennými stěnami spojovanými jílem registrujeme jak ve vesnickém prostředí (např. Nekuda 2007, 101-103), tak u zahloubených suterénů s šikmým rampovitým vstupem (např. Michna 1988, 232). Nicméně většina těchto domů bývá kladena do druhé poloviny 13. až do počátku 14. století.

\section{Analýza nálezů}

Z výzkumu V. Dohnala na předhradí Tepence pochází početná kolekce archeologických nálezů. V drtivé většině případů jde ale o pravěký materiál čítající 6546 předmětů. Do stř̌edověku zařadil V. Dohnal celkem 253 kusů keramických a kovových artefaktů (Dohnal 1980a, 31). V rámci zpracování rozsáhlého nálezového fondu nebylo všem získaným kusům přiřazeno
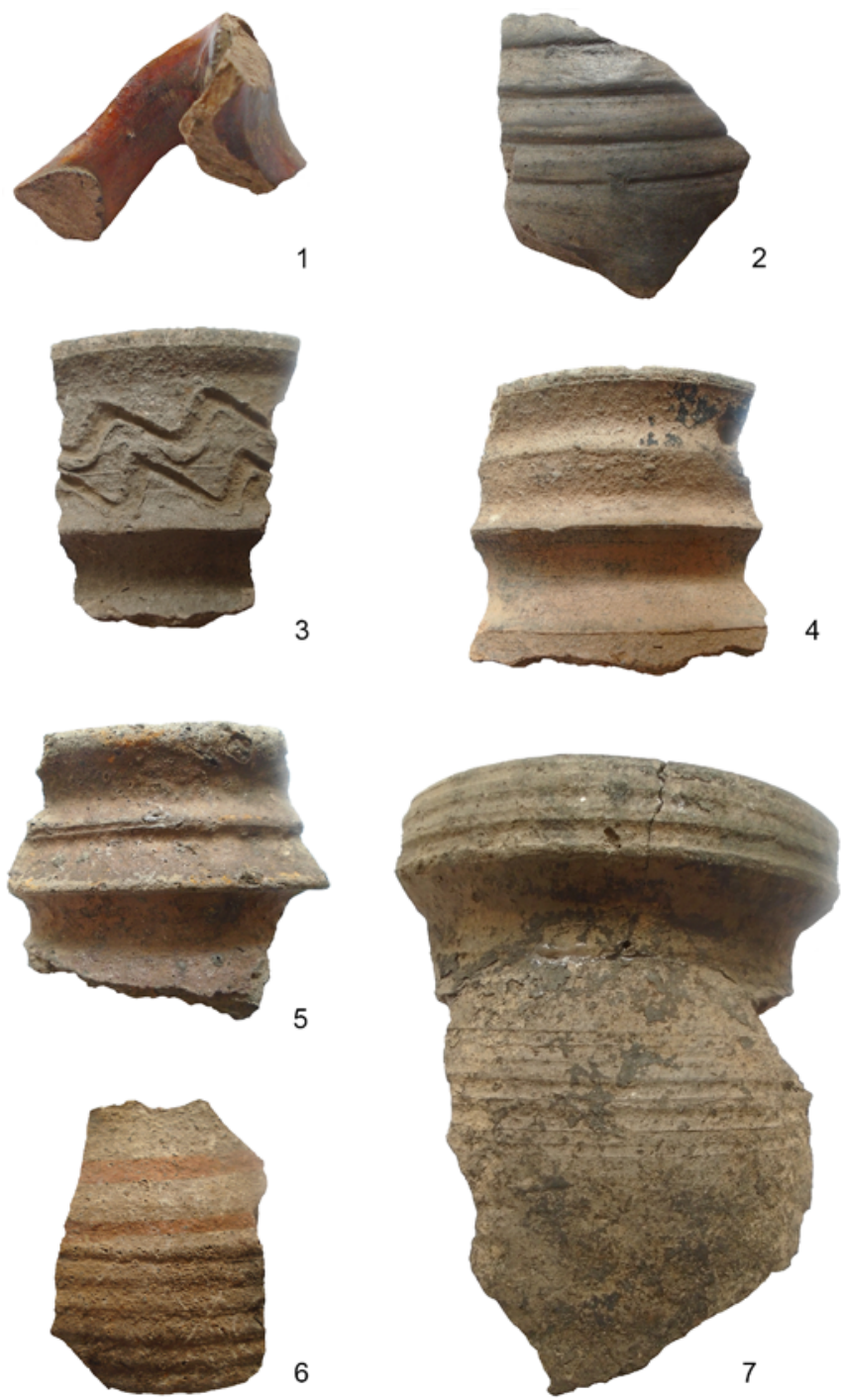

Obr. 14. Hrad Tepenec. Definované keramické třídy. 1 - Třída TEP 6; 2 - třída TEP 7; 3 - třída TEP 2; 4 - trrída TEP 4; 5 - třída TEP 5; 6 - třída TEP 3; 7 - třída TEP 1 Foto L. Hlubek.

Fig. 14. Tepenec Castle. Defined pottery classes. 1 - TEP 6 class; 2 - TEP 7 class; 3 - TEP 2 class; 4 - TEP 4 class; 5 - TEP 5 class; 6 - TEP 3 class; 7 - TEP 1 class. Photo by L. Hlubek.

\begin{tabular}{|c|c|c|c|c|c|c|c|c|c|c|c|c|c|c|c|c|c|c|c|c|c|c|c|c|c|c|}
\hline $\begin{array}{l}\text { Nálezy / } \\
\text { čtverec }\end{array}$ & $\begin{array}{r}\text { Sonda } \\
9 \mathrm{~m}\end{array}$ & $\begin{array}{r}\text { III/ } \\
71\end{array}$ & $\begin{array}{l}1 / \\
72\end{array}$ & $\begin{array}{l}11 / \\
72\end{array}$ & $\begin{array}{r}\text { III/ } \\
72 \\
\end{array}$ & $\begin{array}{l}\text { VIII } \\
/ 72\end{array}$ & $\begin{array}{l}11 / \\
73 \\
\end{array}$ & $\begin{array}{r}\text { III / } \\
73 \\
\end{array}$ & $\begin{array}{r}1 / \\
74 \\
\end{array}$ & $\begin{array}{r}11 / \\
74 \\
\end{array}$ & $\begin{array}{r}\text { III / } \\
74 \\
\end{array}$ & $\begin{array}{r}\text { IV / } \\
74 \\
\end{array}$ & $\begin{array}{l}V / \\
74\end{array}$ & $\begin{array}{r}\text { VI/ } \\
74 \\
\end{array}$ & $\begin{array}{r}\mathrm{VII} / \\
74\end{array}$ & $\begin{array}{r}\text { VIII/ } \\
74 \\
\end{array}$ & $\begin{array}{r}\text { IX / } \\
74 \\
\end{array}$ & $\begin{array}{r}X / 1 \\
74 \\
\end{array}$ & $\begin{array}{r}\mathrm{XI} / \\
74\end{array}$ & $\begin{array}{r}\mathrm{XII} / \\
74 \\
\end{array}$ & $\begin{array}{r}\text { XIII/ } \\
74 \\
\end{array}$ & $\begin{array}{l}1 / \\
75\end{array}$ & $\begin{array}{r}11 / \\
75 \\
\end{array}$ & $\begin{array}{r}\text { III / } \\
75\end{array}$ & $\begin{array}{r}\text { IV / } \\
75 \\
\end{array}$ & Výkop \\
\hline $\begin{array}{l}\text { Kuchyňská } \\
\text { a stolní } \\
\text { keramika }\end{array}$ & & & & 3 & & 8 & & 2 & 1 & 3 & 2 & 4 & & 2 & & 1 & 5 & 91 & 82 & 14 & 2 & & 2 & & 1 & 18 \\
\hline $\begin{array}{l}\text { Stavební } \\
\text { a technická } \\
\text { keramika }\end{array}$ & & & & & & & 1 & & & & & & & & & 1 & & & 2 & & & & & & & \\
\hline $\begin{array}{l}\text { Metalické } \\
\text { nálezy }\end{array}$ & 1 & 1 & 1 & & 1 & 1 & & 2 & & & 1 & & 1 & 2 & 1 & 2 & 1 & 3 & 18 & & & 1 & 3 & 1 & 2 & \\
\hline Celkem & 1 & 1 & 1 & 3 & 1 & 9 & 1 & 4 & 1 & 3 & 3 & 4 & 1 & 4 & 1 & 4 & 6 & 94 & 102 & 14 & 2 & 1 & 5 & 1 & 3 & 24 \\
\hline
\end{tabular}

Tab. 1. Hrad Tepenec. Distribuce vyzvednutých nálezů podle jednotlivých čtverců.

Tab. 1. Tepenec Castle. Distribution of the excavated finds according to the individual square units. 
inventární číslo (číslované nálezy inv. č. A 22745 - A 24 840) a více než dvě třetiny (69\%) materiálu zůstaly neevidovány. Při zpracování středověkého osídlení bylo nutné projít veškeré inventované nálezy a pracovat i s těmi, které V. Dohnal ponechal bez inventárních čísel. Naštěstí jsou u nich vždy uvedeny údaje o místě nálezu (čtverec, hloubka).

Z výzkumu pochází 241 kusů kuchyňské a stolní keramiky, dva zlomky kahanů, částečně poškozený přeslen, zlomek cihly, 49 železných artefaktů a dva fragmenty strusky. Těmto nálezům se budu podrobněji věnovat $\mathrm{v}$ dalším textu. Z nich je inventárním číslem opatřeno 82 kusů ( 57 zlomků keramiky, přeslen, 23 metalických předmětů a struska) a 213 kusů bylo neinventarizováno. Dále je nutné dodat, že 18 keramiky, čtyři železné předměty a dva kusy strusky pochází z objeveného amatérského výkopu v západní části hradní akropole (Dohnal 1980d, 15). ${ }^{20}$ Nálezy z výzkumu byly podle nálezové zprávy trríděny na inventované a neinventované. V žádném případě na jednotlivých sáčcích nenacházíme informaci o tom, co pochází z objektu $\mathrm{v}$ daném čtverci a co se nalezlo mimo něj. Sice vedoucí výzkumu každý čtverec rozdělil na 25 menších čtverců označených písmeny A-E a čísly 1-5, ale i tak není zřejmé, který nález patřil do objektu a co už bylo mimo něj. $Z$ těchto důvodů zpracovávám veškerý materiál společně a nerozlišuji nálezy z obou prozkoumaných objektů a z vrstev.
Zaměř́me-li se na distribuci nálezů (tab. 1), je patrné, že nejvíce nálezů se nacházelo v okolí lehčí stavby (obj. č. 1/74), zejména pak ve čtvercích 10/74 a 11/74, odkud evidujeme zhruba dvě třetiny veškerého středověkého materiálu. Zarážející je skutečnost, že z okolí odkrytého nároží budovy (obj. č. 1/72) máme $\mathrm{k}$ dispozici nálezů výrazně méně (celkem 9 kusů). Byla zde totiž prozkoumána jen malá plocha a navíc se ze čtverce $1 / 72$ se nepodařilo dohledat nečíslované nálezy (Dohnal 1980a, 4). ${ }^{21} \mathrm{~V}$ ostatních čtvercích registrujeme pouze jednotlivé kusy keramiky či ojedinělé metalické artefakty, jejichž distribuce na ploše předhradí nejspíše bude souviset s nakládáním s odpadem ve středověku nebo možnými postdepozičními procesy, popř́ípadě se samotným dobýváním hradu na přelomu 14. a 15. století. Drtivá většina popsaných nálezů pochází z hloubky 0-20 $\mathrm{cm}$. Pouze jeden zlomek keramiky ze čtverce $3 / 74$ byl vyzvednut z hloubky $40-60 \mathrm{~cm}$.

Kuchyňskou a stolní keramiku reprezentuje celkem 241 zlomků (obr. 15-18). Veškerá získaná hrnčina je zastoupena výlučně ve fragmentech, pouze ojediněle máme $\mathrm{k}$ dispozici větší část nádoby, která umožňuje kresebně rekonstruovat celý tvar (např. obr. 17: 5; 18: 12). V celé kolekci nejčastěji evidujeme nezdobené výdutě, méně již okraje, zdobené výdutě, dna a ucha (tab. 2). Většinu získaného materiálu není možné typologicky zařadit. Identifikovat se podařilo zejména hrnce a některé další tvary (tab. 3).

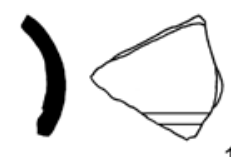

1

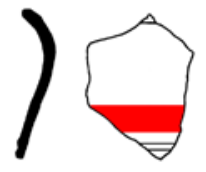

5
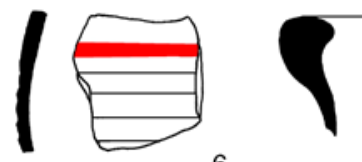

6
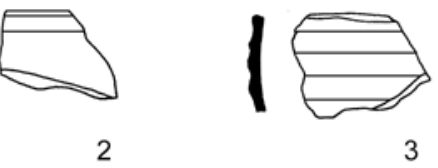

3
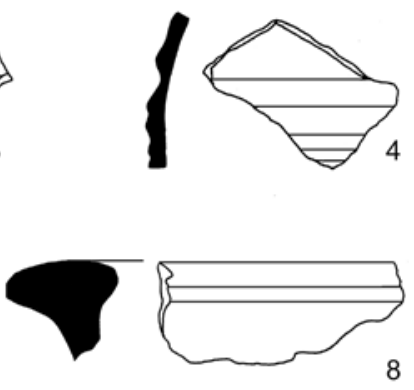

7
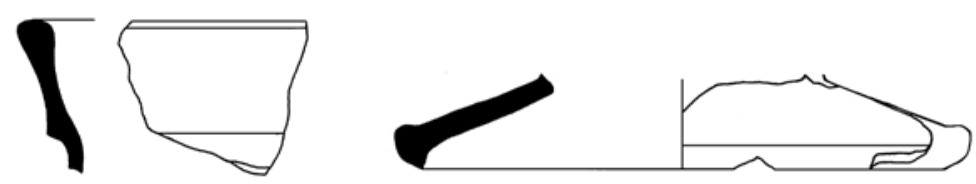

10
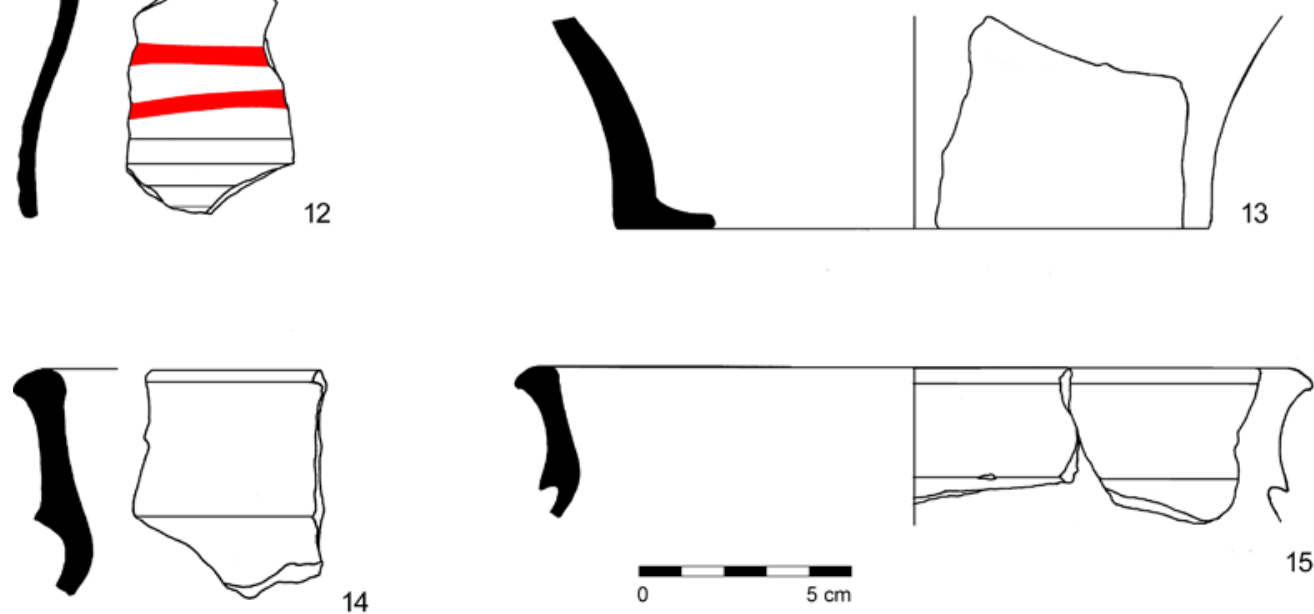

Obr. 15. Hrad Tepenec. Výběr keramických nálezü. Keramická třídy TEP $2-10,13,15$; TEP $3-2,5-8,12$, 14; TEP $4-1,2,7,9$. Kresba L. Hlubek. Fig. 15. Tepenec Castle. Selection of pottery finds, pottery classes TEP $2-10$, 13, 15; TEP 3-2, 5-8, 12, 14; TEP 4- 1, 2, 7, 9. Drawing by L. Hlubek. 


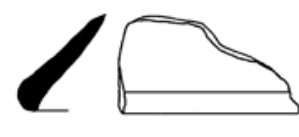

1

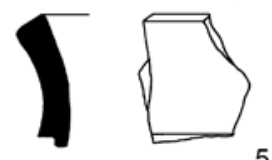

.
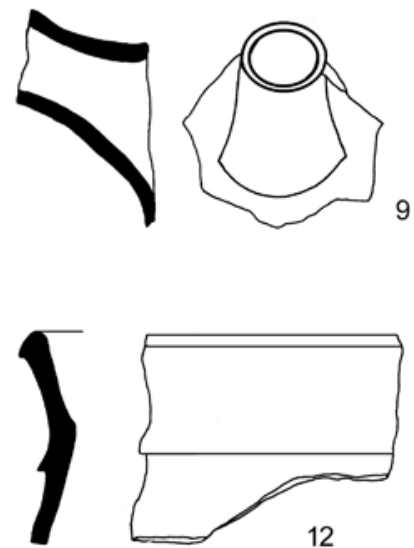

12

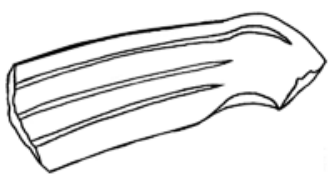

1
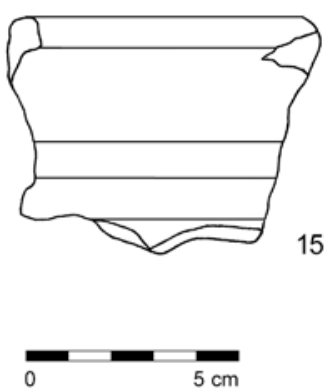

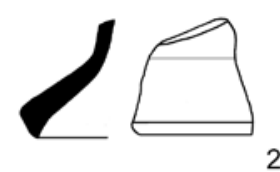

2
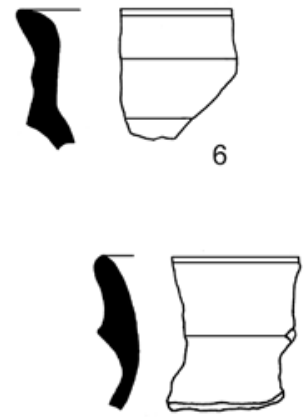

10

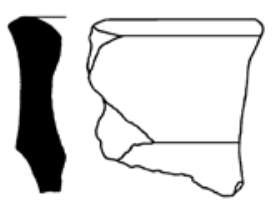

13

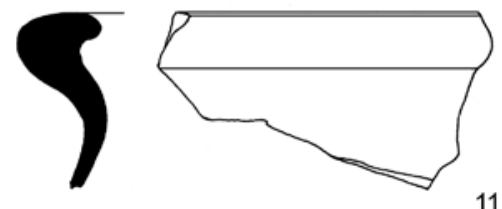

11
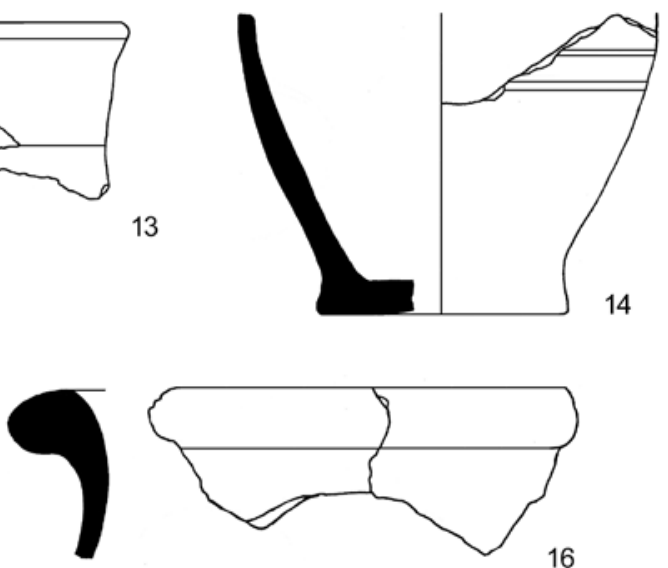

16

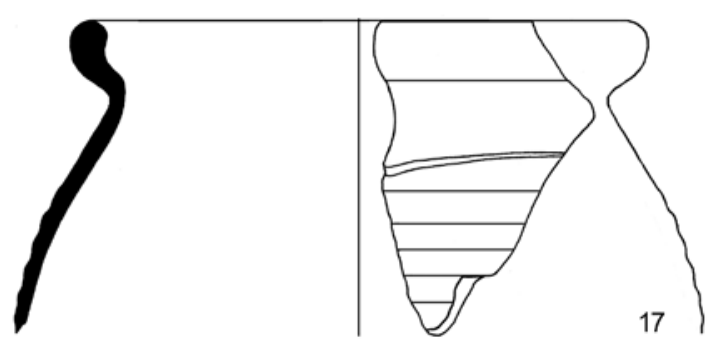

Obr. 16. Hrad Tepenec. Výběr keramických nálezů. Keramická tř̌ídy TEP 2 - 6, 9, 10, 12, 13, 15, 16; TEP 3 - 1-5, 7, 11; TEP 4 - 14, 17; TEP 6 - 8. Kresba L. Hlubek.

Fig. 16. Tepenec Castle. Selection of pottery finds, pottery classes TEP 2 $6,9,10,12,13,15,16$; TEP 3 - 1-5, 7, 11; TEP 4 - 14, 17; TEP 6 - 8. Drawing by L. Hlubek.

\begin{tabular}{lrr}
\hline Část nádoby & Počet ks & V procentech (\%) \\
\hline Okraj & 50 & 22 \\
\hline Dno & 32 & 13 \\
\hline Zdobená výdut & 45 & 18 \\
\hline Nezdobená výdut & 112 & 46 \\
\hline Zlomek ucha & 2 & 1 \\
Celkem & 241 & 100
\end{tabular}

Tab. 2. Hrad Tepenec. Zastoupení zlomků nádob z výzkumu v letech 1971-1975.

Tab. 2. Tepenec Castle. Representation of vessel fragments from the 1971-1975 excavation.

\begin{tabular}{lrr}
\hline Typ nádoby & Počet ks & V procentech (\%) \\
\hline Hrnec & 35 & 14 \\
\hline Hrnek & 2 & 1 \\
\hline Džbán & 1 & 0,5 \\
\hline Poklice & 7 & 3 \\
\hline Pohár & 2 & 1 \\
\hline Mísa & 6 & 2,5 \\
\hline Konvice & 1 & 0,5 \\
\hline Miniaturní nádobka (?) & 1 & 0,5 \\
\hline Neurčeno & 186 & 77 \\
Celkem & 241 & 100
\end{tabular}

Tab. 3. Hrad Tepenec. Zastoupení tvarů nádob z výzkumu v letech 1971-1975. Tab. 3. Tepenec Castle. Representation of vessel shapes from the 1971-1975 excavation. 

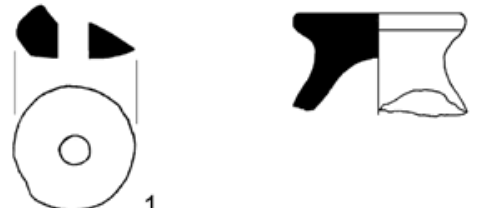

2
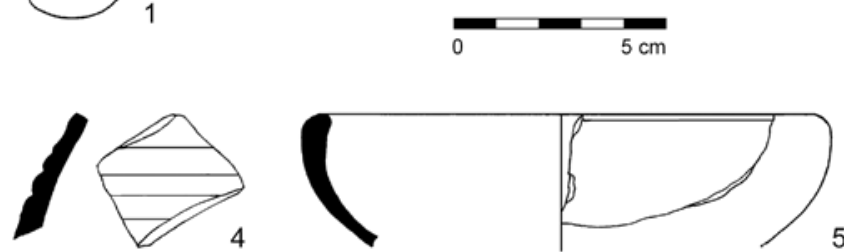

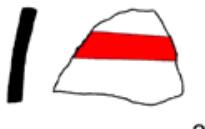

3
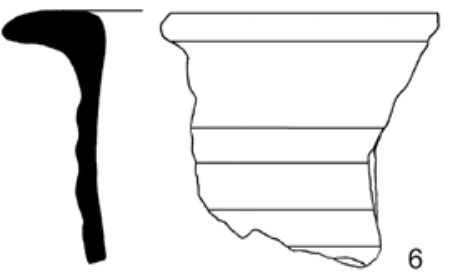

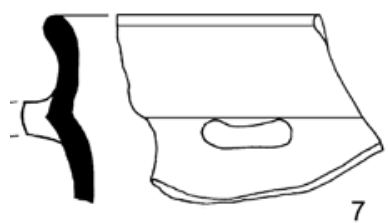

7
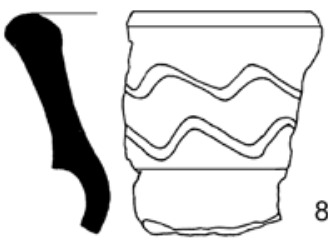

8
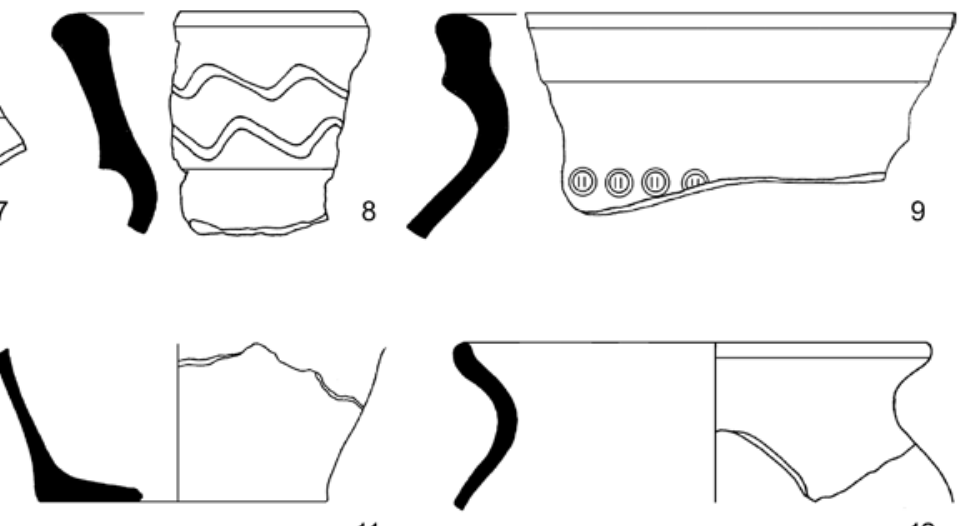

9

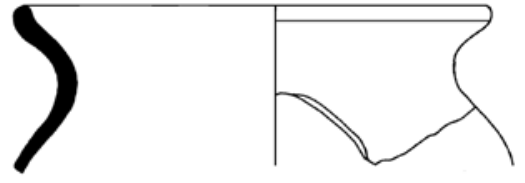

12

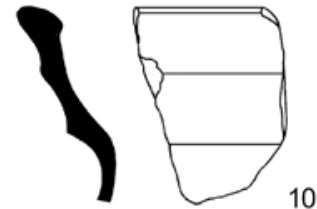

10
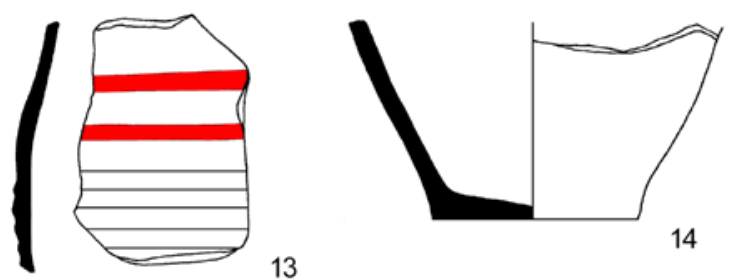

14

13

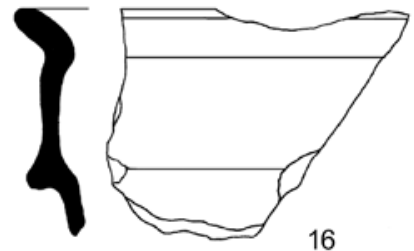

16
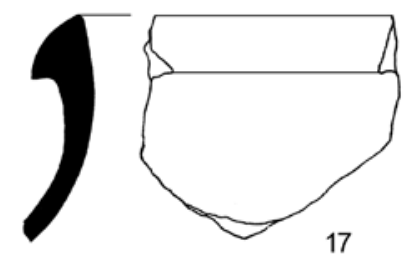

17
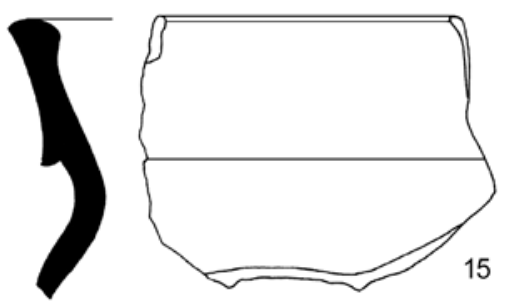

Vyzvednutou kolekci můžeme přiřadit k olomouckému keramickému okruhu vrcholného středověku (k tomu Šlézar 2002, 36-40; Šlézar, Faltýnek 2019, 188-189). Podle keramického těsta a dalších znaků ji lze rozdělit do sedmi základních keramických tř́íd (k tomu např. Čapek et al. 2018, 89-95), které označíme zkratkou TEP 1 až TEP 7 (obr. 14). Pro keramickou třídu TEP 1 (obr. 14: 7) je charakteristický redukční výpal, hrubší těsto s nízkou příměsí grafitu a slídy. K této minimálně zastoupené keramické tř́ídě náleží pouze jedna nezdobená výdut a větší torzo hrnce s římsovitým okrajem (obr. 18: 12), jehož vnější stranu zdobí svazek rýh, výdut a plece několikanásobné rýhy. Zejména na základě dochovaného torza hrnce ostřeného grafitem můžeme třídu TEP 1 zařadit do 13. století s přesahem do první poloviny 14. století (srov. Bláha 1987, 7; Procházka, Žákovský 2019, 212-214). Pokusíme-li se ztotožnit popsanou keramickou

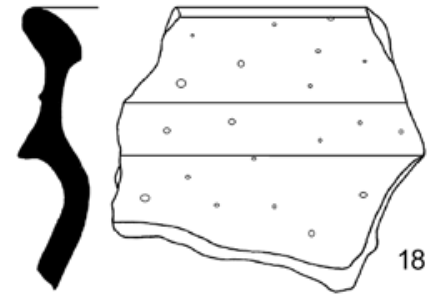

Obr. 17. Hrad Tepenec. Výběr keramických nálezů. Keramická třídy TEP $2-8,9,11,15,16$; TEP $3-2,3$, $5-7,12-14$; TEP $4-1,10,17$; TEP 5 - 18 Kresba L. Hlubek.

Fig. 17. Tepenec Castle. Selection of pottery finds, pottery classes TEP $2-8$, 9, 11, 15, 16; TEP 3 - 2, 3, 5-7, 12-14; TEP 4 - 1, 10, 17; TEP 5-18. Drawing by L. Hlubek. tř́ídu s dosud definovanými keramickými skupinami z hradu Tepence, pak nejspíše jde o III. keramickou skupinu podle V. Vránové a J. Vrány $(2013,294)$.

Hrnčinu ostřenou grafitem evidujeme i z předchozích výzkumů na Tepenci (srov. Rodina 2001, 18; Vránová, Vrána 2013, 294-295). Výskyt této keramiky potvrdila také petrografická analýza, která tuhu zjistila ve třech z pěti vzorků (Gruntová 2015, 37). Podle dosud provedených rozborů keramického materiálu z hradu je však její zastoupení nízké, a proto je možné připustit, že keramika s grafitem v keramickém těstě tvoří pouze starší příměs v souborech ze 14. století, kdy nejspíše doznívá. Ostatně na celém Olomoucku se počítá s výskytem hrnčiny s ř́msovými okraji a ostřené grafitem v průběhu 13. až prvních desetiletích 14. století (srov. Bláha, Sedláčková 1998, 15; Šlézar 2008, 176-178; Šlézar, Faltýnek 2019, 189). 

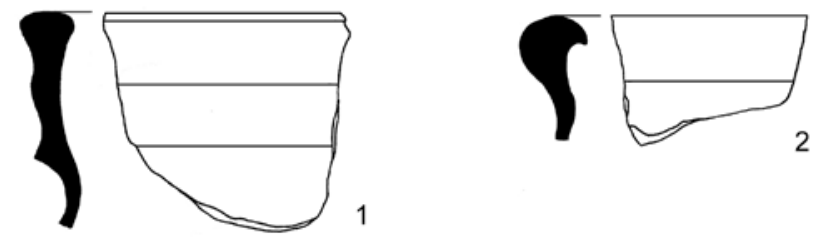
1
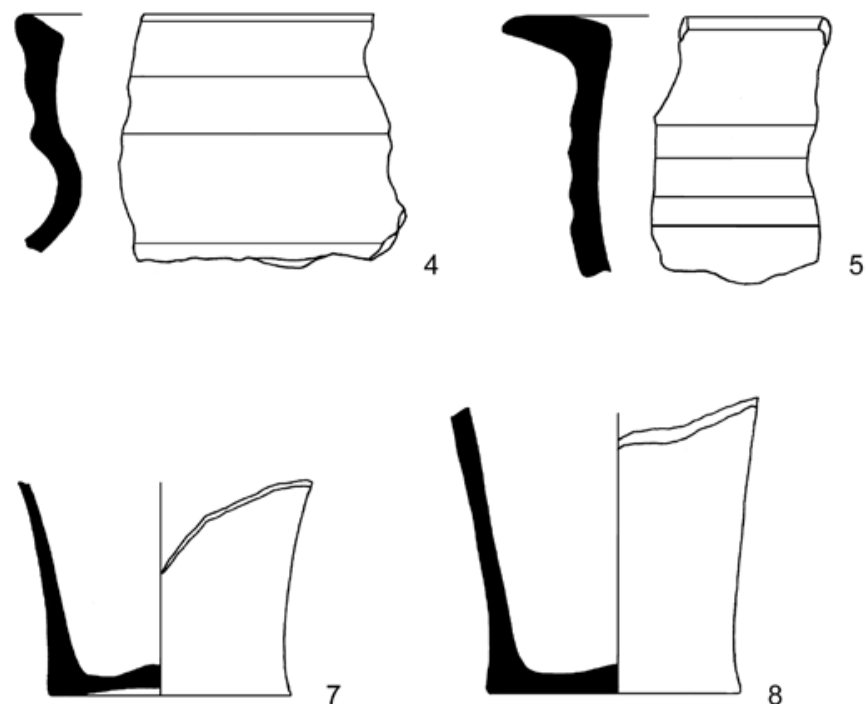

7
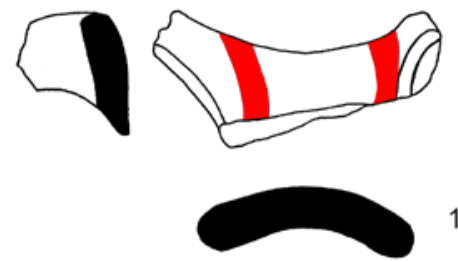

10

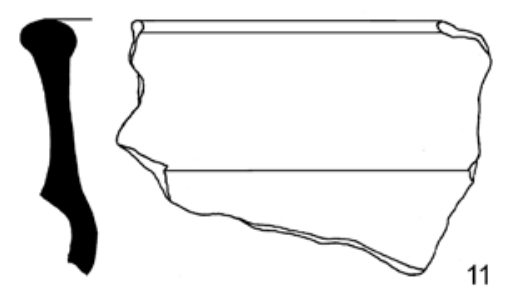

11

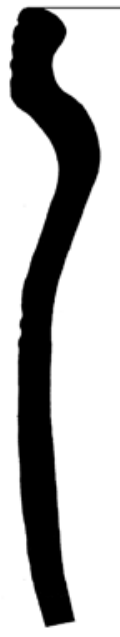

Celkem 46 zlomků keramiky můžeme přiřadit ke keramické třídě TEP 2 (20\%). Ta je také vypálená redukčně do různých odstínů šedé barvy, ale jako ostřivo bylo užito zejména písku a ojediněle slídy. Místy má až krupičkovitý povrch (obr. 14: 3). Pouze v několika málo př́padech registruji grafit v keramickém těstě. Na nádobách jsou zřetelné stopy rotačních rýžek. Na dnech jsou patrné stopy po odříznutí od hrnčířského kruhu i podsýpka. Typologicky se jedná zejména o hrnce, popřípadě hrnky a mísu. Okraje jsou formovány zejména do tvaru okruží (obr. 16: 13; 17: 15; 18: 11) a u mís jsou vodorovně vytažené (obr. 16: 15). Výzdoba keramiky se omezila na tzv. vývalkovitou šroubovici (obr. 16: 15) a rádélko (obr. 17: 9), případně dvojici vlnovek na vnější straně okruží (obr. 17: 8). Podle okrajové profilace hrnců a krupičkového povrchu lze tuto keramickou tř́idu zařadit do průběhu 14. století. Její výskyt je prokázán například na nedalekém hradě Hlubokém, který je v písemných pramenech
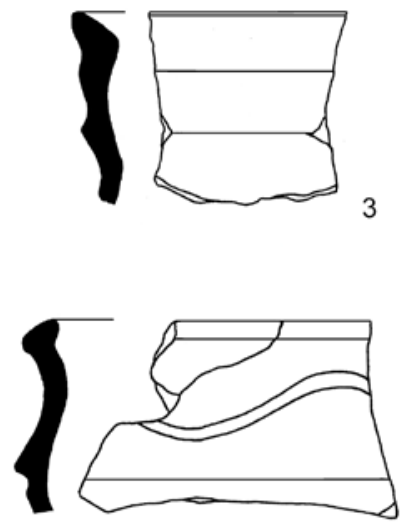

6
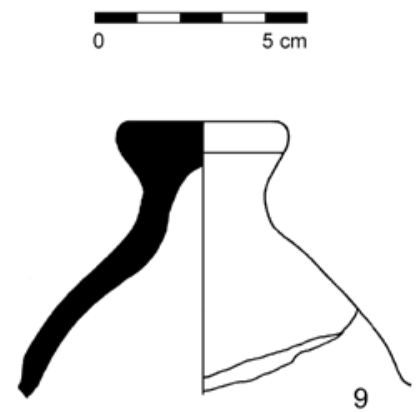

Obr. 18. Hrad Tepenec. Výběr keramických nálezů. Keramická třídy TEP 1 - 12; TEP 2 - 11; TEP 3 - 2, 6-8, 10; TEP $4-1,3-5,9$. Kresba L. Hlubek.

Fig. 18. Tepenec Castle. Selection of pottery finds, pottery classes TEP $1-12$; TEP 2 - 11; TEP 3 - 2, 6-8, 10; TEP 4 - 1, 3-5, 9. Drawing by L. Hlubek. poprvé uveden roku 1351 (Plaček 2001, 218-219; Hlubek 2017, 1). Registrujeme ji také ve městě Olomouci a v keramickém souboru ze zaniklé středověké vsi Prlova (Hlubek 2020a, 30; 2020b, 86). Lze připustit, že tato třída odpovídá II. keramické skupině podle analýzy V. a J. Vránových $(2013,294)$.

Nejvyšší zastoupení v keramickém souboru má keramická třída TEP 3 (obr. 14: 6), k níž lze přiřadit celkem 159 fragmentů keramiky (65\%). Hrnčina je tvrdě vypálená do bílých, bíložlutých až bílošedých odstínů a v keramickém těstě dominuje př́měs písku. Na povrchu nádob registrujeme tzv. krupičkovitý povrch a stopy rotačních rýžek. Dna nádob byla odř́íznuta pomocí struny od hrnčírského kruhu. Okraje jsou zejména ve tvaru okruží (obr. 16: 5; 17: 7) a méně již zaoblené s vnitřním prožlabením (obr. 18: 2), ven vykloněné a ukončené zaoblením (obr. 17: 12). V případě mís jde o vodorovně vytažený okraj (obr. 15: 8; 17: 6). Výzdobu tvoří hlavně tzv. vývalkovitá 
šroubovice (např. obr. 15: 3; 17: 6) a štětcem namalované červené linky (obr. 17: 13; 18: 10). Keramická tř́da TEP 3 se na Olomoucku začíná vyrábět na přelomu 13. a 14. století a během 14. století má v analyzovaných souborech keramiky dominantní zastoupení (srov. Bláha, Sedláčková 1998, 15; Šlézar 2017, 112). Tuto tř́ídu považujeme za shodnou s keramickou skupinou I, podle rozboru keramiky vyzvednuté ze studny na předhradí (Vránová, Vrána 2013, 293-294).

Další keramickou třídu TEP 4 reprezentuje celkem 30 zlomků keramiky (11,5\%). Jde o zlomky tvrdě oxidačně pálené cihlové barvy, s písčitou př́měsí v keramickém těstě (obr. 14: 4). Keramika byla vyrobena vytáčením a dna nesou stopy po odříznutí od hrnčířského kruhu. Převažují okraje ve tvaru různě profilovaných okruží (např. obr. 18: 1, 3, 4), zaoblené s vnitřním prožlabením (obr. 16: 17) nebo šikmo seříznuté (obr. 17: 17). Z výzdobných motivů registrujeme pouze vývalkovitou šroubovici (obr. 15: 9; 16: 17). Podle J. Bláhy se tento typ hrnčiny na Olomoucku objevuje po roce 1400 a doznívá během první poloviny 16. století (Bláha, Sedláčková 1998, 15; Šlézar, Faltýnek 2019, 189).

Keramická třída TEP 5 (4 kusy, 1,5\%) je loštická keramika $\mathrm{s}$ charakteristickou hnědou až hnědošedou barvou a puchýřkovitým či strupatým povrchem, jež však není nijak zdobena (obr. 14: 5). V kolekci registruji pouze tř̀i výdutě a okraj loštického hrnce ve tvaru okruží (obr. 17: 18). Keramika s tzv. loštickým efektem začala být vyráběna ve druhé polovině 13. století, někdy je také označována jako protološtická (např. Goš, Novák 1976; Šlézar 2008, 176). Těžiště výskytu loštických hrnců můžeme klást do závěru 14. až první poloviny 15. století (Měřínský 1969, 89-90; Goš 2007, 63-64). Předposlední keramickou skupinu TEP 6 (obr. 14: 1) zastupuje pouze jeden fragment keramiky $(0,5 \%)$ s oboustrannou vnitřní červenohnědou glazurou a opatřený páskovým ouškem (obr. 16: 8). Není zřejmé, o jaký keramický tvar se jedná. Hypoteticky může jít o blíže neurčenou miniaturní nádobku s ouškem nebo dvojicí oušek. Nálezy keramiky s červenohnědou glazurou zaznamenáváme na střední Moravě zřídka, výraznější zastoupení polévané hrnčiny evidujeme až z průběhu 15. století (např. Šlézar, Faltýnek 2019, 189). Keramiku s červenohnědou glazurou registrujeme jak z prostoru hradního jádra, tak předhradí Tepence (srov. Rodina 2001, 20; Tymonová, Kalábek 1999, 91). Z dalších lokalit lze uvést město Olomouc nebo hrad Hluboký (Bláha 1982, inv. č. A 32 348; Brůnová 2004, 50; Hlubek 2020a, 26, 30-31, obr. 4: 1; Hlubek 2017, 7, obr. 3: 1, 10).

Pro keramickou třídu TEP 7 je charakteristický černý povrch se stř́ibřitým leskem a bílošedým až našedlým lomem (obr. 14:2). Jediný zlomek $(0,5 \%)$ pochází z výkopu na hradní akropoli. Na vnější straně jej zdobí šroubovice (obr. 17: 4). O této keramice z prostoru hradního jádra se zmiňuje ve své práci jak J. Rodina (2001, 22), tak L. Gruntová, která analyzovala jeden zlomek této keramiky z předhradí (Gruntová 2015, 35, 39, obr. na str. 31, vzorek IV). Výskyt této keramiky je na Moravě v analyzovaných souborech poměrně nízký. Na střední Moravě tuto keramiku zaznamenáváme z měst Olomouce, Uničova, Litovle, Prostějova nebo hradu Hlubokého (např. Bláha 1987, 7; Čižmář, Šmíd 2000, 91, obr. 13: 13; Dehnerová et al. 2007, 35-37; Kalábková et al. 2015, 110-111; Hlubek 2017, 7, obr. 3: 2-4). Hojný výskyt této hrnčiny evidujeme také na Brněnsku a Boskovicku (srov. Procházka 1995, 123; 1996, 332; Sedláčková 2020, 27, 42, 69, 97, 159).

Rozpoznané tvary nádob lze hodnotit pouze v omezené míře (tab. 3). Drtivá většina keramických fragmentů je př́lilš malá na to, aby se dal určit aspoň přibližně celý tvar nádoby. U hrnců lze klasifikovat pouze torzo hrnce s římsovitým okrajem a soudkovitým tělem (obr. 18: 12). S ohledem na to, že se v jeho keramickém těstě vyskytuje grafit, můžeme jej zařadit do průběhu 13. až prvních desetiletí 14. století. Podobné hrnce byly nalezeny například ve městech Uničov, Olomouc, Rýmařov nebo ve vsi Žádlovice (Burian, Opravil 1970, 148, 150, tab. I: 1; Michna 1980, 168, obr. 8: 1; Goš et al. 1985, 208, obr. 5: 7, 8; Bláha 1987, inv. č. A 32424 - 32 428; Goš 2007, 15-16, obr. 6: 1, 5, 6).

U ostatních hrnců, popřípadě hrnků, patřících třídám TEP 2-5 jednoznačně převládají okraje ve tvaru okruží, méně se již vyskytují okraje ovalené, ven vykloněné a zaoblené či šikmo seřezané (tab. 4). V získané kolekci jsou zastoupena vysoká okruží (obr. 15: 10, 14, 15; 16: 5, 6, 12, 13; 17: 15; 18: 6, 11), nízká okruží (obr. 16: 10; 17: 7) i okruží se středovým žebrem (obr. 17: 10, $16,18 ; 18: 1,3)$. Měřitelné průměry okrajů dosahují od 105 do $222 \mathrm{~mm}$. Na žádném z dochovaných kusů nebyla zjištěna úchytka a pouze v jednom př́padě máme okraj s odlomeným prožlabeným uchem (obr. 17: 7). Síla stěn se pohybuje nejčastěji od 6 do $8 \mathrm{~mm}$. Pro tyto hrnce lze na střední a severní Moravě najít blízké paralely kladené do 14.-15. století. Namátkou můžeme uvést nálezy z měst Olomouce a Loštic nebo hradů Hlubokého, Šternberka, Tepence, z Náměště na Hané, z intravilánu Chořelic, popřípadě ze zaniklé vsi Prlova (Bláha 1982, např. A 32 308-A 32 311; Burian 1975, 276, obr. 4: 4; Prečanová 1999, 20-21, obr. 8, 9; Goš 2007, obr. 12: 1-4, 61-63; Tymonová 2003, 577-578, obr. 4: 1-3; Brůnová 2004, 50, obr. 13: 3-9, 14: 4-6; Dehnerová, Večeřa 2007, 12-13, obr. 1, 2; Faltýnek 2012, 85, tab. 2: 27-30, 32-38; Vránová, Vrána 2013, 293-294, obr. 8: 1, 6, 12; Šlézar 2017, 112, obr. 21: 1; Hlubek 2020a, 30-31, obr. 3; Hlubek 2020b, 86-87, obr. 2: 2, 3, 5, 6, 10; Hlubek 2017, 4, obr. 1: 4-7, 9).

Daleko nižší zastoupení mají ovalené okraje s vnitřním prožlabením (4 kusy, obr. 15: 7; 16: 11; 18: 2), šikmo seříznuté (1 kus, obr. 17: 17) a ven vykloněné a zaoblené ( 2 kus, obr. 16: 17; 17: 12), které lze nejspíše spojovat s hrnky. Ovalené okraje $\mathrm{s}$ vnitřním prožlabením se objevují zejména $\mathrm{v}$ keramické třídě TEP 3. Známe je také z prostoru předhradí z novějších výzkumů (srov. Vránová, Vrána 2013, 293-294, obr. 8: 14). Poměrně řídce se v keramických souborech ze 14.-15. století na střední a severní Moravě objevuje šikmo seřezaný okraj. Jediný zlomek je vyroben z keramické třídy TEP 4 (např. Goš et al. 1975, tab. 1: 9; Rodina 2001, 26, obr. 2: 22-71/3; Hlubek 2018, 252, obr. 63: 3)

Chronologicky méně citlivé jsou zlomky zvonovitých poklic. K dispozici máme několik okrajů (obr. 15: 11; 16: 1-3) a dva exempláře s knoflíkovitými držadly (obr. 17: 2; 18: 9). Na horních terčících držadel jsou stopy po odrríznutí od hrnčířského kruhu. Okraje poklic jsou šikmo seřezané, symetricky zesílené, nebo šikmo seřezané a rozšířené dovnitř (tab. 4). Jediný rekonstruovatelný okraj poklice má průměr v rovině okraje $130 \mathrm{~mm}$. Poklice byly vyrobeny z bílého krupičkovitého materiálu třídy TEP 3 (16: 1-3) a patří též k cihlově zbarvené třídě TEP 4 (18: 9).

\begin{tabular}{|c|c|c|c|}
\hline Typ nádoby & Typ okraje & Počet ks & V procentech (\%) \\
\hline \multirow[t]{5}{*}{ Hrnec } & Okruží & 31 & 62 \\
\hline & Ven vykloněný a zaoblený & 2 & 4 \\
\hline & Římsovitý & 1 & 2 \\
\hline & $\begin{array}{l}\text { Ovalený s vniřním } \\
\text { prožlabením }\end{array}$ & 4 & 8 \\
\hline & Šikmo seříznaný & 1 & 2 \\
\hline \multirow[t]{3}{*}{ Poklice } & Šikmo seříznaný & 3 & 6 \\
\hline & $\begin{array}{l}\text { Šikmo seříznaný a rozšířený } \\
\text { dovnitř }\end{array}$ & 1 & 2 \\
\hline & Oboustraně zasílené & 1 & 2 \\
\hline \multirow[t]{2}{*}{ Mísa } & Vodorovně vytažený & 4 & 8 \\
\hline & Oboustranně rozšířený & 2 & 4 \\
\hline Celkem & & 50 & 100 \\
\hline
\end{tabular}

Tab. 4. Hrad Tepenec. Zastoupení okrajů nádob z výzkumu v letech 1971-1975. Tab. 4. Tepenec Castle. Representation of vessel rims from the 1971-1975 excavations. 
K těmto poklicím lze dohledat paralely z prostoru střední Moravy datované nejčastěji do 14.-15. století (srov. Bláha 1982, A32 314; Rodina 2001, 31-32; Brůnová 2004, 50, obr. 13: 10-11; Vránová, Vrána 2013, 293-294, obr. 8: 9, 13; Hlubek 2018, 252, obr. 63: 11).

Výrazněji jsou v získaném souboru zastoupené mísy. Zpravidla jsou jejich okraje vodorovně vytažené (obr. 16: 15; 17: 6; 18: 5), nebo oboustranně rozšířené (obr. 15: 2, 8). Horní hranu okraje zdobí svazek rýh ukončených u výlevky (obr. 16: 15), nebo zaznamenáváme svazek rýh a červenou linku (obr. 17: 6). Těla mís lze popsat jako mírně kónická. Pokud můžeme soudit, tak jejich povrch zkrášlovala pouze tzv. vývalkovitá šroubovice (obr. 16: 15; 17: 6; 18: 5). Dva měřitelné průměry okrajů činí 245 a $294 \mathrm{~mm}$. Podobné exempláře mís známe například z hradů a Hlubokého, z města Olomouce, z intravilánu Chořelic nebo ze zaniklé středověké vsi Prlova (Burian 1972b, 107, tab. 99: 2; Prečanová 1999, 22, obr. 16: 6; Rodina 2001, 30-31, obr. 3: 39-69/1, 15; Brůnová 2004, 50, obr. 15: 1; Faltýnek 2012, 85, tab. 2: 31; Hlubek 2020a, 31, obr. 4: 2; Hlubek 2020b, 86, obr. 3: 7).

Pro velkou zlomkovitost již nelze vyhodnotit zbylé identifikované tvary nádob. V získaném souboru máme zastoupeno prožlabené ucho džbánu zdobené červenými linkami (obr. 18: 10). Podle materiálu můžeme toto ucho přiřadit ke keramické tř́ídě TEP 3. Ke konvicím náleží část plecí s šikmo nasazenou výlevkou (obr. 16: 9). Materiál odpovídá keramické třídě TEP 2. Nakonec se ještě zmíním o dvou dnech o průměru 55 a 57 mm (obr. 18: 7, 8). Obě náleží ke keramické tř́ídě TEP 3 a je možné připustit, že jde o dna pohárů. Malé ouško s částí okraje (obr. 16: 8) snad může pocházet z blíže neurčené miniaturní nádobky.

Ve výzdobě keramiky zcela převládá rytá výzdoba v podobě vývalkovité šroubovice (obr. 15: 4, 7; 16: 4, 6; 17: 6, 12; 18: 5), ojediněle v kombinaci s vlnicí (obr. 16: 17). Jen v jednotkách kusů evidujeme jednotlivé rýhy na plecích nádoby (obr. 18: 12). Červenou malbu zaznamenáváme v podobě linky (obr. 17: 3; 18: 10) nebo dvojice linek nad sebou (obr. 15: 12), někdy v kombinaci se šroubovicí (např. obr. 15: 6, 12; 17: 12). Také vnější plochy okrajů hrnců jsou ve vyzvednutém souboru poměrně řídce zastoupeny. Jde o jednu vlnici (obr. 18: 6) a dvojici vlnic (obr. 17: 8) na ploše okrajů ve tvaru okruží a svazek rýh na římsovitém okraji (obr. 18: 12). Zdobeny jsou také horní hrany mís, a to svazkem rýh (obr. 16: 15; 17: 6), případně i červenou malbou (obr. 17: 6). Všechny uvedené typy dekorace nádob evidujeme běžně i z dalších středomoravských a severomoravských lokalit datovaných do 14.-15. století (Nekuda, Reichertová 1968, 142-143; Goš 1980, 372; Hlubek 2017, 2).

Červeně malovanou keramiku ojediněle zaznamenáváme v prostoru střední a severní Moravy již v průběhu druhé poloviny 13. století. Jde o nečetné nálezy ze Smilova Hradiska na Prostějovsku a ze sídliště v Bezručově ulici v Rýmařově, popř́padě lze připočítat několik kusů z jímek prozkoumaných na staveništi obchodního domu Prior v Olomouci, které J. Bláha kladl do přelomu 13. a 14. století (k tomu Nekuda, Reichertová 1968, 255, obr. 111: 1-4; Goš et al. 1985, 216-217, obr. 6: 6; 9: 7; Bláha 1987, 7, např. A 32 461, A 32 495). Na sledovaném území pozorujeme rapidní nárůst červeně malované keramiky během 14. století (např. Bláha 1987, 7). Obvykle se vyskytuje na bílé až bíložluté krupičkovité hrnčině v podobě vodorovných linek nebo vlnice mezi dvojicí červených linek, popř́padě kapky (Goš 1980, 372). V 15. století její četnost klesá a objevuje se např́iklad na loštických pohárech s věncem oušek pod okrajem. Za jedno z míst její výroby jsou pokládány nedaleké Loštice (srov. Nekuda, Reichertová 1968, 142; Goš 2007, 77). Chronologický význam červeně malované keramiky $\mathrm{v}$ rámci souboru $\mathrm{z}$ Tepence není př́liš vysoký, nebot je vázán na keramické třídy TEP 3, TEP 4, poprrípadě TEP 5 .
Pouze v jednom př́ípadě zaznamenáváme užití rádélka v podobě kruhu s dvojicí svislých čárek uvnitř (obr. 17: 9). Obecně lze konstatovat, že výzdoba provedená pomocí rádélka se během 14. století na střední a severní Moravě objevuje velmi málo (srov. Goš 1980, 372). Z výzkumů V. Buriana pochází také několik zlomků keramiky zdobených rádélkem. Tato dekorace má podobu obdélníčků, př́ípadně kombinace drobných trojúhelníků a kosočtverců (Rodina 2001, 19). Výskyt rádélkové výzdoby je ve 14.-15. století častější na Prostějovsku, ale ani tam nenacházíme totožný vzor (srov. Žákovský 2006, 148, tab. XXXI: 3-11, XXXII: 1-10; Čižmář, Šmíd 2000, 81, 91, obr. 4: 10-13, 15; 15: 6-8; Fojtík 2015, 293-294, obr. 5: 5-7, 11). Patrně nejbližší paralelu k tepeneckému dekoru najdeme v materiálu z hradu Vartnova, byt zde jde o kruh s tečkou uprostřed (srov. Kouřil 1988, 294, tab. II: 25; Kouřil et al. 2000, 358, obr. 260: XXX).

Shrneme-li výše prezentovanou analýzu, pak za nejstarší složku prezentovaného souboru označujeme keramickou třídu TEP 1 (2 kusy). Patrně jde o starší keramické zboží v souboru ze 14. století. Datování zbylého materiálu nám usnadňují písemné prameny, podle nichž počátky stavby hradu klademe do 30. až počátku 40. let 14. století, a roku 1406 je Tepenec uveden jako zbořený (např. Vránová, Vrána 2016, 31-33). Tuto dataci podporuje také jediná vyzvednutá mince. Jde o předběžně určený český fenik z let 1392-1393 (Tymonová 2002, 221). Drtivá většina nálezů bude náležet zejména do druhé poloviny 14. až počátku 15. století. V keramickém souboru má výrazné zastoupení keramická tř́ída TEP 3 (65\%), která je dlouhodobě považována na Olomoucku za charakteristickou hrnčinu pro celé 14. století (srov. Bláha, Sedláčková 1998, 15; Šlézar 2008, 176-178; Šlézar, Faltýnek 2019, 189). Nižší zastoupení má podobná keramická třída TEP 2 (20\%), která se odlišuje zejména redukčním výpalem šedých tónů, a keramická tř́ída TEP 4 (11,5\%) vypálená do cihlových odstínů; počátky její výroby se kladou do doby kolem roku 1400. Keramické tř́ídy TEP 5, TEP 6 a TEP 7 mají velmi nízké zastoupení. Běžně tuto keramiku zaznamenáváme i na dalších středomoravských lokalitách datovaných do 14.-15. století. Za importované zboží lze označit pouze zlomky loštických hrnců. Veškerá ostatní hrnčina patřila k standardně dostupnému zboží.

Další oporu pro datování tepeneckého souboru poskytuje také srovnání s nádobami, do nichž byl uložen poklad mincí z Olomouce - Nových sadů. Poklad pražských grošů byl uložen do země na konci 14. století. Ražby se nacházely ve dvou nádobách a dno další nádobky sloužilo jako poklička. První nádoba má okraj ve tvaru okruží, druhá šikmo seříznutý. První hrnec byl vypálen do šedé až šedočerné barvy a druhý do bíložluté (Burian 1958, 260-261; Nekuda 1980, 393, 407). Keramický soubor z výzkumu na předhradí Tepence lze srovnávat také s nálezy ze IV. horizontu osídlení tvrze v Rýmařově, který je datován do druhé poloviny 14. až počátku 15. století (Goš et al. 1975). Tento horizont navíc pomáhá datovat dvojice pražských grošů Karla IV. a Václava IV., které byly nalezeny v areálu zdejšího sídla (Goš, Karel 1992, 231).

Obrátíme-li pozornost od kuchyňské a stolní hrnčiny, dostáváme se k málo zastoupeným skupinám keramiky stavební a technické. Ke stavební keramice náleží pouze torzo cihly. Bohužel jde o kus bez jediné celé strany. Maximální měřitelné rozměry činí $89 \times 49 \times 40 \mathrm{~mm}$. Na lomu je dobře pozorovatelné ostř̌ivo v podobě písku a drobných křemenů. Podle J. Rodiny měly cihly vyzvednuté $\mathrm{v}$ areálu hradního jádra Tepence šírku mezi 110 až $120 \mathrm{~mm}$ a sílu $70 \mathrm{~mm}$ (Rodina 2001, 36). Cihly s podobnou silou známe např́klad z hradů Melice, Strálek nebo z Nového hradu u Hanušovic (srov. Michna 1974, 73; Goš, Karel 1999, 109; Goš 2016, 289). Z dalších středomoravských lokalit lze uvést 


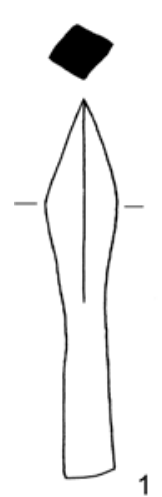

1

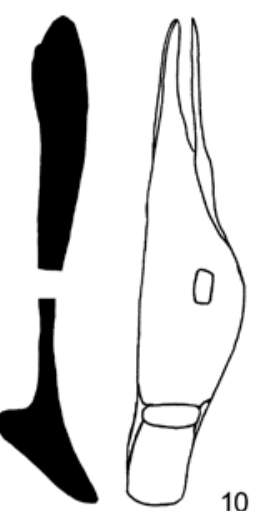

10

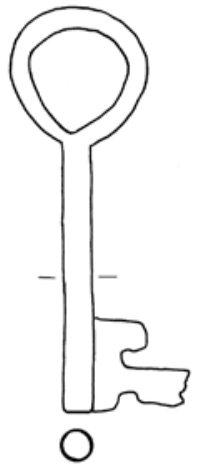

11
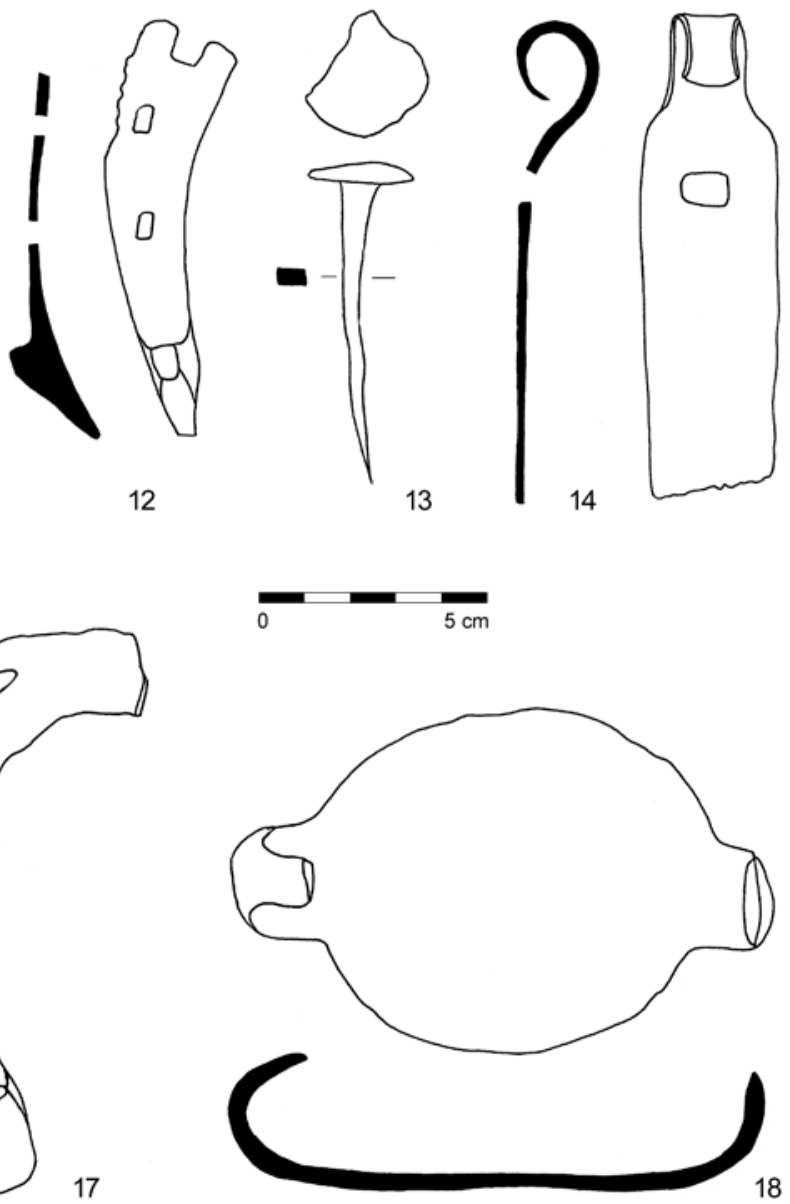

Obr. 19. Hrad Tepenec. Výběr metalických nálezü. Kresba L. Hlubek. Fig. 19. Tepenec Castle. Selection of metallic finds. Drawing by L. Hlubek. užití cihel z areálu města Olomouce, hradu Hlubokého nebo z kartuziánského kláštera v Dolanech (srov. Bláha 1995, 34; Hlubek, Schenk 2020, 150; Nekuda, Reichertová 1968, 59; Hlubek 2017, 9). Cihla pochází z volné plochy předhradí (čtverec 8/74) a dnes ji není možné spojovat s žádným objektem.

Technickou keramiku reprezentují dva kahany a neúplný přeslen. Částečně poškozený přeslen byl nalezen ve čtverci $2 / 73$. Má kruhový tvar se středovým otvorem a na povrchu cihlovou barvu, která se svým provedením blíží keramické skupině TEP 4. $\mathrm{Na}$ jeho ploše neregistrujeme žádnou výzdobu. Celkový průměr dosahuje $30 \mathrm{~mm}$, výška $13 \mathrm{~mm}$ a průměr středového otvoru činí 7 mm (obr. 17: 1). S keramickými přesleny se běžně setkáváme na nejrůznějších středověkých lokalitách z 13.-15. století (např. Nekuda, Reichertová 1968, 63; Březinová 2007, 51-57, 60). Chronologicky nejsou nijak citlivé, ale v případě nálezu z hradu Tepence jej můžeme zařadit do 14 . až počátku 15 . století.
Dvěma zlomky jsou zastoupeny fragmenty kahanů. Dochovaly se pouze v nevelkých zlomcích, v prvním případě jde o část hubičky a v druhém o okrajový fragment (obr. 17: 5), jehož celkový průměr činí $120 \mathrm{~mm}$. Oba byly vypáleny do bílé až béžové barvy, a je možné je přiřadit ke keramické třídě TEP 3. V obou př́padech jde o nálezy z okolí nadzemní stavby (obj. č. 1/74). Kahany byly nalezeny také v areálu hradu Tepence (Rodina 2001, 34-35; Tymonová, Kalábek 1998, 91). Analogické nálezy registrujeme např́íklad z Loštic nebo z hradů Šternberka, Melic a Lelekovic (Michna 1974, 73, obr. 6: 6; Unger 1999, 88-89, obr. 94: 7, Dehnerová, Večeřa 2007, 13, obr. 3: 1, 2; Hlubek 2018, 252, obr. 63: 10).

Kolekci metalických nálezů (obr. 19-20) tvoří celkem 49 artefaktů, ${ }^{22}$ jeden kus se ve sbírkách olomouckého muzea nepodařilo dohledat (tab. 5). Nejčastěji máme k dispozici stavební kování, zlomky podkov a hroty šípů. Ostatní nálezy se vyskytují 

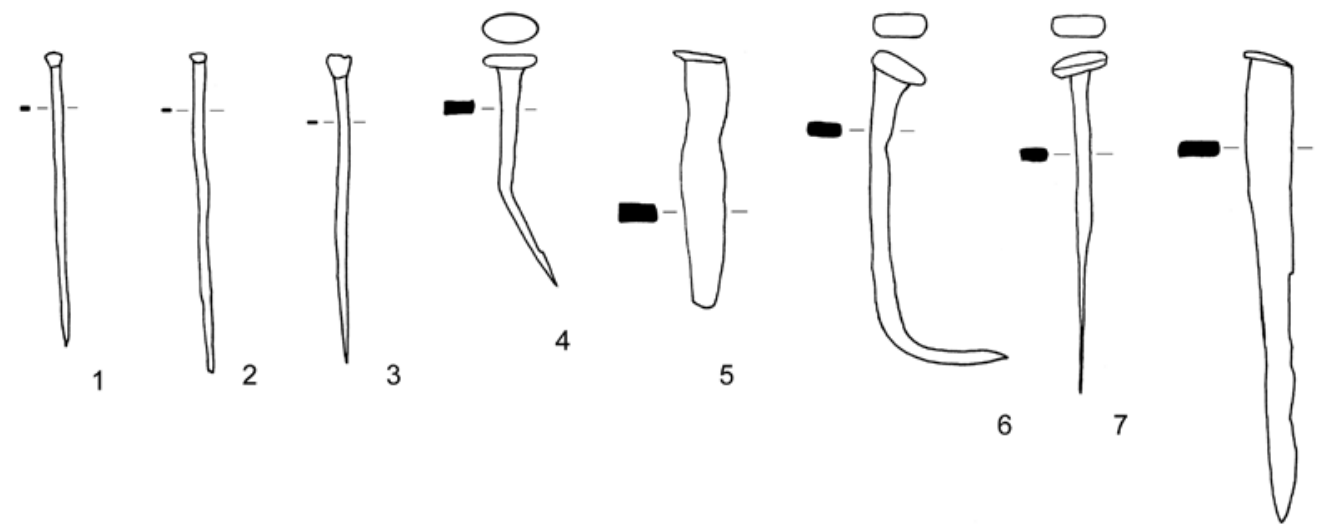

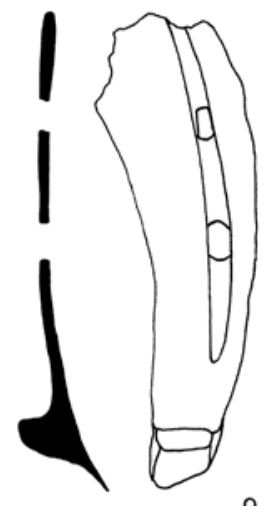

9
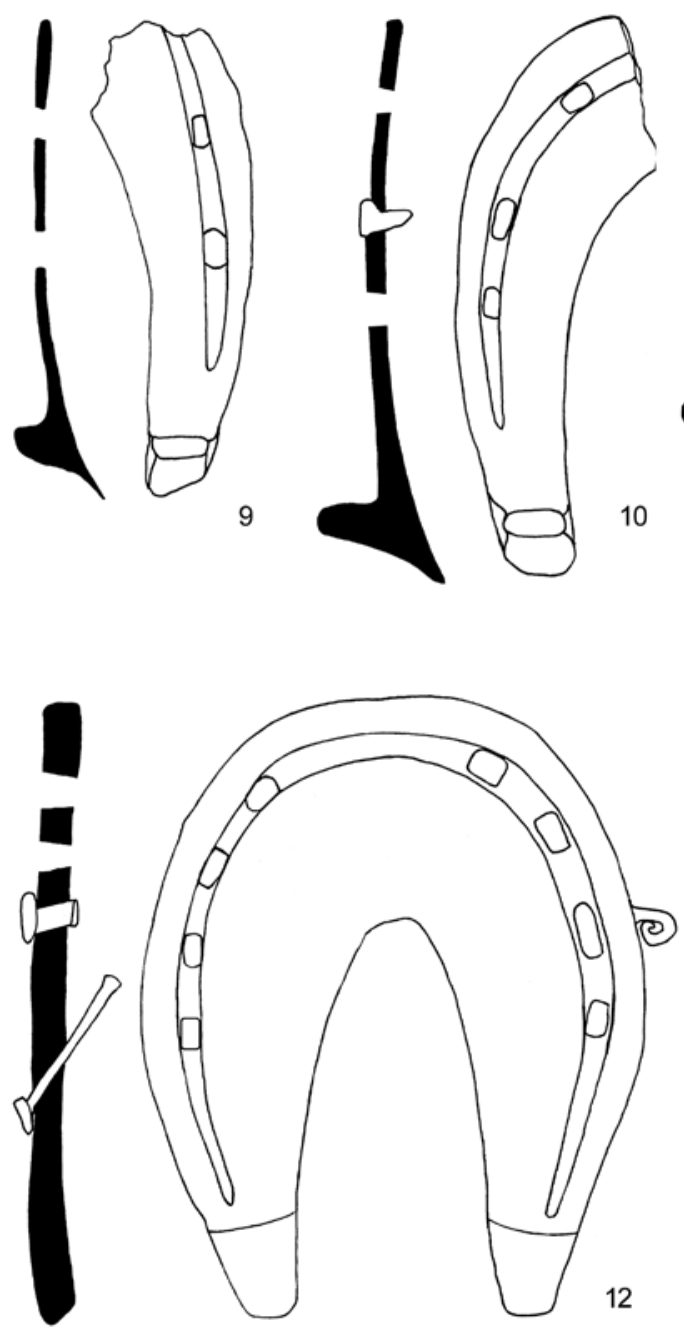

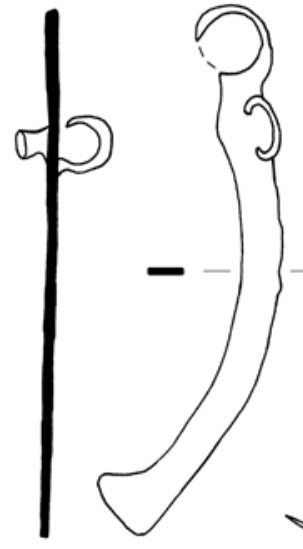

13

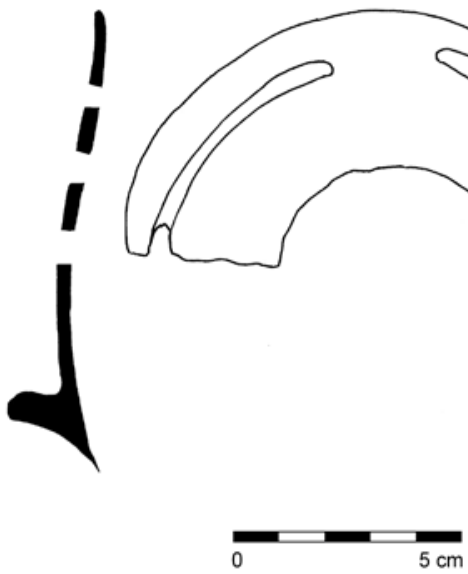

Obr. 20. Hrad Tepenec. Výběr metalických nálezů. Kresba L. Hlubek. Fig. 20. Tepenec Castle. Selection of metallic finds. Drawing by L. Hlubek. pouze v jednotkách kusů - otočný klíč, dveřní pant, fragment postranice udidla, přezka, stupadlo třmene, skoba/svorka, železný kroužek a dva blíže neučené předměty (obr. 18; 19). Drtivá většina kovových nálezů byla konzervovaná nedlouho po ukončení výzkumu, a proto je dnes jejich stav na dobré úrovni. Zhruba polovinu metalických artefaktů evidujeme z obou prozkoumaných objektů, popř́ípadě z jejich nejbližšího okolí. Z lehčí stavby (obj. č. 1/74) pochází celkem 22 nálezů a tři kusy z míst kamenné budovy (obj. č. 1/72). Další čtyři artefakty a strusku našel V. Dohnal ve výkopu v západní části hradní akropole. Šlo o trojici podkov, část postranice udidla a dva amorfní kusy strusky. Zbylé exempláře byly vyzvednuty z obou sond z hloubky 0-20 cm. Při dělení metalických předmětů se budu držet typologie kovových předmětů podle R. Krajíce (2003). Do této části také zahrnu dva nalezené kusy strusky.
Ke skupině zbraní a zbrojí náleží pět hrotů šípů, ale jeden kus se nepodařilo dohledat. Není ani vyobrazen v nálezové zprávě, a proto jej není možné nijak hodnotit. Ve třech př́ípadech jde o hroty opatřené tulejkou (obr. 19: 1-3), u posledního kusu nelze rozhodnout, nebot̉ se z něj dochovala pouze hrotová část (obr. 19: 15). Všechny mají rombický př́ičný průřez hrotu a maximální šíře dosahují zhruba v poslední třetině jejich délky. U celých exempláŕů osciluje jejich délka od 74 do $85 \mathrm{~mm}$; poslední dosahuje maximální délky $44 \mathrm{~mm}$. Obrátíme-li pozornost na hroty dochované v úplnosti, mohu všechny přiřadit ke Krajícově typu B IIa (Krajíc 2003, 186-187, obr. 150), respektive typu T 2-5 podle B. Zimmermanna (Zimmermann 2000, 51-53). Jejich hmotnost činí 30, 35, 40 g. Je možné předpokládat, že ve všech případech šlo o střelivo do kuší. Podle analýzy R. Krajíce se tento typ hrotů na předměstí Sezimova Ústí vyskytoval vůbec 


\begin{tabular}{|c|c|c|c|}
\hline Skupina & Předmět & Počet & Celkem \\
\hline Zbraně a zbroj & Hrot šípu & 5 & 5 \\
\hline \multirow{4}{*}{$\begin{array}{l}\text { Doklady o využití } \\
\text { koňské síly }\end{array}$} & Podkova & 7 & \multirow[t]{4}{*}{10} \\
\hline & Třmen & 1 & \\
\hline & Udidlo & 1 & \\
\hline & Přezka & 1 & \\
\hline \multirow[t]{5}{*}{ Stavební kování } & Klíč & 1 & \multirow[t]{5}{*}{31} \\
\hline & Dveřní pant & 1 & \\
\hline & Hřebík & 23 & \\
\hline & Klínec & 5 & \\
\hline & Skoba/svorka & 1 & \\
\hline \multirow[t]{2}{*}{ Neurčené } & Kroužek & 1 & \multirow[t]{2}{*}{3} \\
\hline & Neurčeno & 2 & \\
\hline Výrobní odpad & Struska & 2 & 2 \\
\hline Celkem & & & 51 \\
\hline
\end{tabular}

Tab. 5. Hrad Tepenec. Zastoupení metalických nálezů z výzkumu V. Dohnala. Tab. 5. Tepenec Castle. Representation of metallic finds from V. Dohnal's excavations.

nejčastěji (Krajíc 2003, 187). V širším evropském milieu patřily tyto hroty $\mathrm{k}$ běžnému druhu střeliva, v ojedinělých případech se vyskytovaly již ve 12 . století, svého největšího rozšírení však bezpochyby doznaly až v průběhu 14. a 15. století (srov. Zimmermann 2000, 51-53; Serdon 2005, 104-105).

O výskytu hrotů šípů kosočtvercového příčného profilu s cylindrickou tulejkou na hradě Tepenci se zmiňoval již V. Burian (1971b, 66, tab. 46: 5); snad př́liš nepochybíme, budeme-li předpokládat, že totožné typy známe i z prostoru předhradí (srov. Tymonová 2002, 226, obr. 10: 9; Vránová, Vrána 2005, obr. 19: 3; 2016, obr. 36). Typově totožné střelivo známe i z dalších moravských lokalit. Namátkou lze uvést hrady Hluboký, Pustiměř, Melice, Nový Hrad u Hanušovic, tvrz v Rýmařově, kartuziánský klášter v Dolanech, popřípadě prostor předpokládaného bojiště či ležení u Tovačova (Unger 1974, 194-196, obr. 1: 5; Brůnová 2004, 52, obr. 15: 8; Procházka, Žákovský 2019, 224, obr. 8: 10-11; Goš 2016, 282-283; Hlubek 2010, 494, obr. 2: 7, 8; 3: 9, 10; Frait 2001, 50-54, tab. 27: 1, 2, 5, 9-15; Žákovský, Schenk 2017, 43, kat. č. 196-242). Všechny tyto uvedené nálezy náleží do 14.-15. století, kdy se tento typ hrotů šípů na středověkých lokalitách objevuje naprosto běžně. Militaria nalezená během výzkumu V. Dohnala nevytvářela žádné nápadné koncentrace. Hroty byly získány z plochy čtverců 3/73, 9/74, 10/74, 2/75 a 4/75. Dva kusy pocházejí z blízkosti jižního řezu opevněním, dva z plochy předhradí a poslední z okolí lehčí stavby (obr. č. 1/74). V současné chvíli můžeme s obležením hradu Tepence teoreticky spojovat pouze kusy vyzvednuté z okolí opevnění.

Výrazněji je zastoupena kolekce nálezů ze skupiny dokladů o využití koňské síly. Tuto kategorii reprezentuje sedm podkov, zlomek postranice udidla, stupadlo třmene a drobná přezka, u níž je možná interpretace jako součást upínacího aparátu ostruhy. Nejprve se budeme věnovat vyzvednutým podkovám (obr. 19: 10, 12, 17; 20: 9-12). Šest z nich se dochovalo ve zlomcích a jedna v úplnosti. Zlomky reprezentují neúplná ramena ukončená ozubem o šírce 17-36 mm a dva větší fragmenty se stř̌edovým obloukem. U tř́i exemplářů známe jejich celkovou délku, která dosahuje 101, 122 a 134 mm. Čtyři kusy mají rýhu pro podkováky, přičemž u dvou kusů víme, že byla v čelní partii podkovy přerušená (obr. 19: 17; 20: 11) a v jednom případě je průběžná (obr. 20: 12). Zjištěný počet otvorů pro podkováky je $\mathrm{v}$ pěti př́padech šest, $\mathrm{v}$ jednom osm a u posledního exempláře nelze určit (obr. 19: 10). V plně dochované podkově se v otvorech nachází dvojice podkováků (obr. 20: 12) a jeden podkovák se dochoval ve fragmentu (obr. 20: 10). Podle trŕ́dění podkov od R. Krajíce $(2003,102-104$, obr. 94, 95) je možné pět kusů přiřadit k variantě 4c (obr. 19: 10, 17; 20: 9-11, dva kusy bez rýhy, tři s rýhou pro podkováky), jeden k typu 4b (obr. 19: 12) a poslední nejspíše k typu 2 (obr. 20: 12), respektive k typům VI/4 (Kaźmierczyk 1978, 97-103), IV/5 (Kaźmierczyk 1978, 74-78) a I/1 (Kaźmierczyk 1978, 19-30), které byly vyčleněny na základě studia slezského materiálu.

Vysoké zastoupení podkov Krajícova typu 4c koresponduje se zjištěním V. a J. Vránových, kteří konstatovali, že tato varianta podkov na Tepenci zřetelně dominuje (Vránová, Vrána 2012a, 739). Také V. Burian ve své práci uváděl, že podkovy z prostoru hradního jádra byly zpravidla opatřeny rýhou a kvádř́ḱkovými ozuby (Burian 1984, 14-15). Podobné nálezy datované do 14.-15. století zaznamenáváme z hradů Hlubokého, Rabštejna, Melic, Rychleb nebo dolanského kartuziánského kláštera (Burian 1964, 6, obr. 3: 3; Unger 1974, 196, obr. 2: 4; Kouřil et al. 2000, 318, obr. 222: 4; Frait 2001, 42-43, tab. 18: 5, 6; Brůnová 2004, 52, obr. 15: 9; Hlubek 2013, 137, obr. 9: 2, 3). Zaměříme-li se na distribuci podkov, pak přesnou polohu známe pouze u čtyř exemplářů, nebot tři našel V. Dohnal ve výkopu. Čtyři kusy z prostoru hlavní sondy se nacházely ve čtvercích 6/74, 1/75, 2/75 a 4/75. Dvě z nich registrujeme v okolí opevnění na jižní straně předhradí a dva kusy byly nalezeny na ploše předhradí.

Ke skupině kovových artefaktů spojených s využitím koňské síly dále náleží tři neúplné předměty, a to zlomek postranice udidla, stupadlo třmene a nejspíše také malá přezka. Ze čtverce 3/75 bylo vyzvednuto stupadlo třmene vykované do oválného tvaru a z něj vycházejí odlomená ramena (obr. 19: 18). Nález není možné typologicky jednoznačně zařadit, byt̉ se svým tvarem blíží ke Krajícově typu 4 (Krajíc 2003, obr. 101, 102), respektive typu V/B W. Świętosławskieho (Świętosławski 1990, 57-58). Obdobně tvarované stupadlo registrujeme z jednoho třmene z prostoru hradního jádra (srov. Novotný, 1970, 63; Burian 1981b, 25, obr. na str. 26: 32-70), což by umožňovalo jeho dataci do 14.-15. století. Z prostoru výkopu pochází kromě trojice podkov také zlomek postranice udidla. Jde o plochou obloukovitě zahnutou tyčinku ukončenou očkem a druhým okem postaveným kolmo k ploše (obr. 20: 13). Na základě několika podobných nálezů se domníváme, že jde o část postranice pákového udidla. Podobné exempláře zaznamenáváme např́ílad z velitelského stanoviště pod hradem Lichnicí, z hradů Lelekovice a Rokštejna, popř́ípadě z předhradí hradu Strádova (Frolík, Musil 2013, 162-163, obr. 27: 4; Unger 1999, 126-127, 137: 2; Měřínský 2007, 112, obr. 64: 2469; Musil 2019, 77, obr. 6: 5), které jsou datované zejména do průběhu 15. století. Je-li určení artefaktu správné, pak jej můžeme zařadit do doby fungování hradu. Hypoteticky můžeme $\mathrm{k}$ této kategorii přiřadit drobnou železnou přezku. Ta má mírně lichoběžníkovitý tvar a částečně odlomený středový trn. Dochované rozměry činí $22 \times 16-22$ mm (obr. 19: 8). Pochází ze čtverce $5 / 74$, čili z plochy předhradí. Snad sloužila k upínání ostruh, ale vyloučit nelze ani jiné užití (např̀. spínání řemene nebo opasku). Přesnější interpretace těchto menších nálezů je obtížná (srov. Měchurová 1995, 171; Krajíc 2003, 127-128).

Nejpočetnější zastoupení mají artefakty náležící do skupiny stavebního kování (31 kusů). Tuto kategorii tvoří 23 hřebíků, pět klínců, skoba/svorka, zlomek dveřního pantu a otočný klíč. Klíč s téměř kruhovým okem, dutým dř́kem a částečně dochovanou bradou (obr. 19: 11) lze bezpečně přiřadit k typu X podle R. Krajíce (2003, 92-94, obr. 90). Tyto klíče se na našem území objevují během 13.-15. století. Z podobných nálezů můžeme uvést 
exempláře z měst Litomyšle a Ostravy nebo ze zaniklých vsí Bystřec a Konůvky (Měchurová 2013, 192, 194, obr. 7 dole; Belcredi 2006, 347, tab. XXXIV: 4; Měchurová 1995, 179, tab. XII: 14; Vích 2015, 207-208, obr. 3: 1). Klíč z hradu Tepence byl vyzvednut ze zjištovací sondy v blízkosti kamenné stavby (obj. č. 1/72).

V okolí stavby (čtverec 8/72) se podařilo najít také část dveřního závěsu o délce $106 \mathrm{~mm}$. Je vykovaný z pásu železa o šířce $29 \mathrm{~mm}$ a na konci stočený do oka. Jeho plocha byla perforována zhruba obdélným otvorem o rozměrech $11 \times 6 \mathrm{~mm}$ (obr. 19: 14). Pro přesnější datování nejsou tyto kusy př́íliš vhodné. Četné nálezy kovových plechů $\mathrm{s}$ otvory uváděl $\mathrm{z}$ prostoru hradního jádra Tepence B. Novotný (1970, 63). Podobná pásová kování dveř́i či bran známe například z hradů Rokštejna, Melic či Ježova hradu, kartuziánského kláštera v Dolanech, popřípadě zaniklých středověkých vsí Konůvky a Bystřec (Burian 1964, 4, obr. 4: 1; Unger 1974, 197, obr. 3: 5; Měŕínský 2007, 108, obr. 58: 4, 5; Žákovský 2006, 134, tab. 62: 1; Frait 2001, 26, tab. 9: 12; Měchurová 1995, 171-172; Belcredi 2006, 349, tab. XXXVI:3-6). Nejsou však vhodná k jemnějšímu datování.

Nejpočetnější skupinu kovových nálezů z výzkumu představují hřebíky a klínce. Z pěti získaných klínců se dochovaly čtyři v úplnosti a z posledního pouze horní polovina. Celé kusy dosahují délky od 93 do 108 mm (obr. 19: 4, 5, 7; 20: 8) a zlomek klínce má délku $58 \mathrm{~mm}$ (obr. 20: 5). Na průřezu mají tvar obdélníku o rozměrech $7 \times 2,5$ až $9 \times 3,5 \mathrm{~mm}$. Podle typologie R. Krajíce (2003, 67-68) jde ve všech případech o jím vyčleněné typy VIIIa. S ohledem na jejich nálezy v prostoru hradního jádra Tepence, odkud V. Burian (1979b, obr. 1:2, tab. 1) popsal celkem 24 kusů, je zbytečné uvádět nějaké další analogie. Jejich rozložení na ploše předhradí nevytváří žádné shluky, ani se nenalezly v blízkém okolí některé ze staveb. Byly vyzvednuty ze čtverců 3/74, 8/74, 9/74 a 7/74, odkud pochází dva kusy.

Nejvyšší zastoupení mají mezi kovovými nálezy hřebíky, kterých je celkem 23 kusů. Podle typologie R. Krajíce (2003, 64-67) je můžeme přiřadit k typům s horizontální hlavicí (typ IIa, 1 kus, obr. 19: 13), kř́ídlové (typ IIIa, 4 kusy, obr. 19: 6; 20: 4, 6, 7) a s vertikální hlavicí (typ Vc, 18 kusů, obr. 20: 1-3). Hřebíky s vertikální hlavicí, tzv. šindeláky, dosahovaly délky 30-77 mm. Nalezené kusy s kř́ílovou hlavicí mají délku od 66 do 103 mm. Podobné typy stavebních kování registroval na Tepenci i V. Burian (1979b, 22-23, obr. 1: 2, 4, 12). Tyto artefakty nejsou nijak datačně citlivé, proto upustíme od výčtu dalších analogií.

Zajímavá je distribuce hřebíků, nebot 18 kusů s vertikální hlavicí pochází ze čtverce 11/74, kde podle V. Dohnala mohly vytvářet malý depot (Dohnal 1980a, 43-44). Avšak v dokumentaci k výzkumu není k dispozici žádný nákres či fotografie, které by tento „hromadný nález“ zachycovaly. V nálezové zprávě je pouze uvedeno, že tyto hřebíky byly na malé ploše. Šest z nich je dochovaných v úplnosti (obr. 20: 1-3) a dosahují délky 70-77 mm, ostatní kusy jsou polámané. Jejich délka činí od 33 do $58 \mathrm{~mm}$. Podle všeho se tato kumulace kování nacházela mimo vlastní lehčí stavbu (obj. č. 1/74). Tím pádem tuto představenou interpretaci není možné zpětně nijak verifikovat. Mohlo jít jak o malý depot, tak o zcela náhodnou kumulaci stavebních kování, což se s ohledem na poškozené exempláře zdá pravděpodobnější.

Uvnitř lehčí stavby ve čtverci 10/74 se podařilo najít dva hřebíky s křídlovou hlavicí (obr. 20: 4, 7). Je možné připustit, že se uplatnily při stavbě tohoto objektu. Tři hřebíky pocházejí z prostoru informativní sondy, z plochy předhradí (čtverec 1/71) a nároží kamenné stavby (čtverec 8/72). Nakonec se ještě zmíním o drobné dvojramenné skobě nebo svorce o délce $65 \mathrm{~mm}$, která má kvadratický průřez (obr. 19: 16). Pochází z okolí lehčí stavby (obj. č. 1/72). Její interpretace není jednoznačná, neboť určitě nejde o klasickou „stavební“ skobu. Je možné př̀edpokládat, že byla využita jiným způsobem, např́íklad jako součást uzamykacího mechanismu dveří (srov. Krajíc 2003, 77).

Blíže neučené předměty reprezentuje dvojice tyčinek, z nichž jedna je ohnutá do tvaru háku (obr. 20: 14), a železný kroužek o průměru $43 \mathrm{~mm}$ (obr. 19: 9). Ze čtverce 3/72 pochází kroužek vykovaný do ploché železné tyčinky. Určení původního účelu kroužku bývá značně nejasné (srov. Měchurová 1995, 171). Mohl se uplatnit jako opasková přezka, vodící kroužek udidla nebo část dveřní petlice. V př́ípadě zbylých dvou železných tyčinek nelze ani rámcově určit typ artefaktu.

Nakonec se ještě zmíníme o nalezené strusce, kterou vedoucí výzkumu získal z výkopu. Jde o dva středně velké kusy kompaktní strusky. Oba mají spíše konkávní tvar. Jejich maximální měřitelné rozměry činí $132 \times 92 \times 43 \mathrm{~mm}$ a $125 \times 83 \times 43 \mathrm{~mm}$; hmotnost je $537 \mathrm{~g}$ a 471 g. Výskytem strusky na ploše předhradí Tepence se nedávno zabývali V. Vránová, J. Vrána a M. Moník, kteří dospěli k závěru, že v prostoru předhradí existovala kovářská dílna. Strusky se na ploše předhradí koncentrovaly zejména v okolí objektů č. 147 a 196, dále v jihozápadní části a v některých terénních depresích. V závěru článku připouštějí, že struska mohla také sloužit ke zpevnění povrchu předhradí (Vránová et al. 2014, 639-645, obr. 1). Zda je tomu tak i v případě obou kusů získaných od nálezce, nelze dnes rozhodnout.

\section{Diskuze}

V letech 1971-1975 proběhl v prostoru předhradí hradu Tepence první archeologický výzkum, který prokazatelně doložil osídlení jeho plochy v době fungování hradu. V. Dohnalovi se zde podařilo částečně prozkoumat dva středověké objekty, přičemž oba pokládal za stavby s nadzemní konstrukcí a předpokládal jejich hospodářskou funkci (Dohnal 1980a, 43-44). Další objekty byly odkryty během následných záchranných výzkumů v prostoru předhradí (souborně Vránová, Vrána 2016, 50-58). Jako první vyslovil názor, že by mohlo jít o nezdařilou lokaci města, T. Velímský (1992, 132), který v podstatě vycházel pouze z půdorysu lokality s relativně pravidelně rozmístěnými zahloubenými objekty a předběžně publikovanými výsledky z výzkumu V. Dohnala. V podobném duchu se vyjádřili také V. Goš a J. Halama (2013, 213-214). V práci sumarizující výsledky výzkumů na hradě Tepenci se V. Vránová a J. Vrána přiklonili k interpretaci, že by mohlo jít o podhradní městečko (Vránová, Vrána 2005, 25-38; 2016, 65). Tento výklad přejal také J. Doležel (2008, 488). Domníváme se, že se můžeme v současnou chvíli zamyslet nad zástavbou na předhradí znovu a pokusit se tento výklad rozvést.

Z tzv. zakládací listiny hradu Tepence z roku 1340 plyne, že markrabě Karel od olomouckého biskupa kupuje pouze samotnou horu Tepenec s bezprostředním okolím (CDM VII, 202-203, č. 279). Na tomto území zamýšlel vystavět hrad spravovaný purkrabím. Podle listiny měl purkrabí složit slavnostní př́sahu nejen markraběti, ale také olomouckému biskupovi. Referovaná listina zároveň omezuje některé pravomoci purkrabího (například, že nesmí brát dřevo z lesa na stavbu hradu, obtěžovat poddané biskupa a kapituly nebo je nutit pracovat na stavbě hradu). V mladších písemných pramenech nacházíme jména některých purkrabích. Jmenovitě známe Kuníka z Drahotuš, Svatobora Ganzara z Domašova, Unku z Majetína a po něm purkrabství získal nechvalně proslulý Jindřich z Nevojic (Štěpán 2000, 9). P. Bolina předpokládal, že do markraběcích válek se stávali purkrabími lidé spojení s olomouckým biskupstvím. Připustil také možnost, že prvním purkrabím Tepence mohl být Racek z Dolan (Bolina 2004a, 174).

Dále nás kupní smlouva z roku 1340 informuje o tom, že pokud by někdo v budoucnu nově zřídil v sousedství mýtnou stanici (theloneum) či založil tržní místo (forum), tak lidé olomouckého biskupa nebudou nuceni tato místa navštěvovat, a zároveň 
je nebude zadržovat, zatýkat nebo na nich uplatňovat své pravomoci tepenecký purkrabí. Z této formulace vyplývá, že v době sepsání listiny u hradu Tepence neexistovala mýtná stanice ani tržní místo, které je pro zařazení do kategorie městeček zásadní (např. Mezník 2001, 63-64). Ze stylizace textu kupní smlouvy plyne, že tuto pasáž lze vnímat jako ochranu poddaných olomouckého biskupství pro př́ípad zrrízení trhu či mýtné stanice kdekoliv v okolí. S ohledem na skutečnost, že v závěti markraběte Jana Jindřicha z roku 1371 (CDM X, 137-142, č. 118) není uvedeno tržní místo ani mýto, lze mít za to, že u hradu Tepence nikdy nic takového nevzniklo. Tento výklad je nepřímo podporován absencí drobných kovových nálezů (např. lotových závaží, vážek či drobných ztrátových mincí) z areálu předhradí. Taktéž schází jasné doklady o provozování řemeslné výroby. V zásadě máme doloženo pouze provozování kovářství v areálu předhradí a velmi zběžně zmínky o nalezeném nářadí - kladiv, vrtáků a seker (Vránová et al. 2014, 639-647; Vránová, Vrána 2016, 64). Podobná situace jako s trhem a mýtným místem tomu bude i s úřadem popravce. V textu kupní smlouvy z roku 1340 je užita formulace, „pokud by v budoucnu byl zde ustanoven“.

Dále je na místě otázka tzv. Jívovské cesty známé z listinných falz hlásících se do roků 1220 a 1269 (CDB II, 412-415, č. 376; CDB V/2, 194-195, č. 599), které lze nejspíše datovat do závěru 13. až počátku 14. století (Novák 2020, 257, 262-265). V literatuře panuje shoda na tom, že již od pravěku vedla kolem dnešní obce Jívové dálková komunikace spojující Olomoucko se Slezskem. Její počátek v prostoru Nízkého Jeseníku bývá lokalizován do blízkosti obce Dolany, odkud cesta směřovala přes Jívovou dále k Moravskému Berounu a do Slezska. Její průběh dokládají také stopy vyjetých kolejí dochovaných v terénu nebo objevených pomocí lidarového snímkování (srov. Bolina 2004b, 93-113; Dehnerová, Šlézar 2015, 78; Martínek, Vránová 2018, 114). Problematikou průběhu komunikací v prostoru Nízkého Jeseníku se zabýval P. Bolina (2004a, 169-174), který připouštěl možnost, že se Karel IV. pokoušel založením Tepence Jívovskou cestu přeložit tak, aby lidé museli projet přes celnici u hradu.

V. Dohnal v nálezové zprávě z výzkumu uváděl, že jedna větev této cesty mohla vést Bělkovickým údolím. Uvedenou možnost podporuje zejména umístění brány v jihozápadní části tepeneckého předhradí (Dohnal 1980a, 8). Nicméně pohled na mapy I. a II. vojenského mapování může naznačovat spíše možnost, že komunikace nevedla Bělkovickým údolím, ale příčně přes ně. Spojovala tak město, dnešní Jívovou, s městem Uničovem a vedla přes Tepenec, Domašov u Šternberka, Mladějovice a Újezd.

S Jívovskou cestou také úzce souvisí otázka staršího osídlení před vybudování Tepence. Dosud se na katastru Jívové nepodařilo zaznamenat žádné raně středověké nálezy, i když na základě toponym užívaných v pramenech můžeme o raně středověkém osídlení na plošině Nízkého Jeseníku uvažovat. Rozvoj osídlení v okolí hradu Tepence lze předpokládat během poslední třetiny 13. století v souvislosti s exploatací nerostného bohatství ze strany rodu Šternberků (Hlubek 2019, 14-17).

$\mathrm{Z}$ areálu hradu Tepence máme $\mathrm{k}$ dispozici keramiku ostřenou grafitem, obvykle řazenou do 13. až počátku 14. století (srov. Rodina 2001, 24; Vránová, Vrána 2013, 295-296). K výskytu této hrnčiny je možné připustit dva výklady. Tato keramika představuje starší príměs v dosud zpracovaných souborech, což může korespondovat s tím, že její zastoupení v nich je velmi nízké. Druhou možností je, že mohlo docházet ke krátkodobému využití lokality např. k odpočinku, přenocování, k pastevectví atd. V současné době však nelze rozhodnout, která z těchto možností je správná. Doplňme ještě, podle M. Plačka měl Tepenec dvě stavební etapy s tím, že v první fázi vznikl hrad, vnitřní hradba s valem a až později byla dostavěna vnější hradba s pětibokou baštou (Plaček 2001, 640).
Složitější vývoj hradu naznačuje také analýza keramiky z výzkumů V. Buriana provedená J. Rodinou. Rímsovité okraje hrnců se nalézaly ve všech kontextech, nejméně jich obsahovala svrchní humusová vrstva (Rodina 2001, 24). Nezbývá než doufat, že zpracování některého dalšího keramického souboru povede k rožrešení otázky nejstaršího osídlenív areálu hradu a předhradí Tepence.

Obrátíme-li pozornost $\mathrm{k}$ archeologicky prozkoumaným stavbám, pak vyvstává problém s jejich interpretací. Jako nepravděpodobná varianta se jeví ztotožnění zástavby na předhradí se vsí Jívovou. Vůbec první zmínka o vsi Jívové se objevuje v roce 1357, kdy se v písemných pramenech objevil Henslin z Jívové (Kuča $2000,746)$. V roce 1364 patřila ke vsím, které přispívaly na údržbu mostů přes řeku Moravu u olomouckého hradu (CDM IX, 251-252, č. 336). Následně se ves objevuje v třetí závěti markraběte Jana Jindřicha (CDM X, 137-142, č. 118) a po zničení hradu Tepence byla darována dolanskému kartuziánskému klášteru (CDM XIII, 407, č. 372). Sice se připouští její zpustošení během 15. století, ale to bývá spojováno s husitskými (Koudela, Šindlářová 2012,29) nebo česko-uherskými válkami (Bartoš, Kovářová 1999, 16). V literatuře poněkud zapadlo líčení V. Štěpána, který uvedl, že po přepadení Tepence v první fázi markraběcích válek byl hrad značně poškozen a na čas jeho správu převzal Unka z Majetína (např̀ Štěpán 2000, 9). Budoucí purkrabí Jindřich z Nevojic se uchýlil do Jívové, poddanské vsi hradu, kde doplnil svou družinu (Štěpán 2002, 171). Na druhou stranu dosud nevíme, kde přesně se tato ves nacházela, nebot z intravilánu dnešní obce Jívové je zatím znám pouze raně novověký materiál (Hlubek 2019, 12-13), který zřejmě souvisí s novým vysazením Jívové před polovinou 16. století (Bartoš, Kovářová 1999, 16; Kuča 2000, 746). Zároveň se v nejbližším okolí hradu nenacházejí stopy po plužinách, které bychom zde očekávali.

Pokud jsme výše odmítli variantu, že zástavbu v areálu tepeneckého předhradí není možné interpretovat jako podhradní městečko, nebot̉ se zdá vysoce pravděpodobné, že nikdy zde neexistovalo tržní místo, pak je nutné uvažovat o jiné formě sídelního útvaru. Lze navrhnout jinou možnost, a to považovat předhradí Tepence za latrán, čili opevněnou část napojenou na hrad (např. Durdík 2012, 181). Podle Josefa Hložka jsou pro latrány typické znaky absence městských práv a kostela s farní funkcí. Obvykle tyto útvary postrádají vlastní název, který by je odlišoval od hradu (Hložek 2016, 296-297). Nicméně latrány jsou typické zejména pro jihočeský region - např́íklad Př́iběnice, Český Krumlov, Rožmberk a Velešín (srov. Rusó, Smetana 1994, 330; Hložek 2016, 296) a ojediněle se s nimi setkáváme v dalších českých regionech (Hložek 2016, 297-298). Z Moravy lze uvést pouze hrad Stagnov na Vyškovsku s městečkem, roku 1480 nazvaným Hrádek (Rusó, Smetana 1994, 331; Plaček 2001, 583).

Můžeme předpokládat, že se osídlení na předhradí Tepence rozvíjelo postupně v návaznosti na provoz Jívovské cesty spojující Olomoucko se Slezskem. K nárůstu zástavby mohlo také dojít v souvislosti se stavbou hradu nebo s jeho opravami po roce 1381 , případně během dostavby hradby na severní straně předhradí. K této práci bylo nepochybně zapotřebí zaměstnat větší množství lidí, včetně kvalifikovaných řemeslníků. Další rozvoj osídlení ukončily markraběcí války, které trvaly s přestávkami téměř 25 let. Zjištěný počet staveb není nijak závratný, ale je potřeba si uvědomit, že areál předhradí nebyl prozkoumán v úplnosti, byt se v posledních sezónách výzkum zaměřuje na exkavaci na povrchu viditelných objektů. Nicméně i předložený výklad je poplatný aktuálnímu stavu zpracování všech provedených archeologických výzkumů na hradě i předhradí Tepence. Do budoucna bude potřeba vyhodnotit nemalou část prozkoumaných půdorysů staveb, což může přinést nové impulzy $\mathrm{k}$ interpretaci zástavby v prostoru předhradní. 


\section{Celkové shrnutí}

Hrad Tepenec nechal vybudovat moravský markrabě Karel během 30. až 40. let 14. století. Za tímto účelem koupil od olomouckého biskupa Jana Volka horu Tepenec a blízké okolí. Fortifikace měla sloužit zejména k posílení královské moci v dané oblasti a k ochraně Jívovské cesty spojující Olomoucko se Slezskem. Hrad byl během své existence minimálně dvakrát obležen. Poprvé roku 1381, následně došlo k jeho opravě. Znovu jej dobylo vojsko vedené hejtmanem Janem Štěnětem z Bělin na počátku 15. století. Zř́íceninu roku 1406 daroval markrabě Jošt kartuziánskému klášteru v Dolanech.

Fortifikace se skládala z hradního jádra a rozsáhlého předhradí, na kterém se původně rozkládalo hradisko lidu popelnicových polí. Popisovanou lokalitu od 60. let 20. století postupně odtěžuje blízký kamenolom. Z těchto důvodů probíhají na Tepenci záchranné výzkumy od roku 1968 až dodnes. Tento text je v zásadě prvním ucelenějším pokusem o zpracování střredověké komponenty osídlení vycházející z výzkumu realizovaného v letech 1971-1975.

Vedoucí výzkumu V. Dohnal položil v prostoru předhradí nejprve $1 \mathrm{~m}$ širokou zjištovací sondu dlouhou $30 \mathrm{~m}$ a v dalším roce otevřel hlavní sondu, která protala celý opevněný areál od SZ k JV. I když byl výzkum zaměřen na řešení otázek pravěkého osídlení lokality, tak se V. Dohnalovi podařilo částečně prozkoumat dva nadzemní objekty, které datoval do 14. století. První stál blíže k severní straně nedaleko od průběhu opevnění. Odkryté nároží stavby svíralo úhel $75^{\circ}$ a mělo kamenné stěny spojované jílem (obj. č. 1/72). Podle V. Dohnala šlo o nadzemní objekt hospodářského účelu. Druhá stavba (obj. č. 1/74) se nacházela ve čtvercích 10/74-12/74. Šlo také o objekt lehčí konstrukce, snad o nějaký přístřešek či budovu se srubovou konstrukcí spojovanou hřebíky. Analýza vyzvednutých nálezů prokázala, že těžiště osídlení na předhradí Tepence můžeme klást do doby fungování hradu.

Zástavbu v prostoru předhradí nelze jednoznačně interpretovat. Domníváme se, že není možné ji označovat za podhradní městečko, nebot's vysokou mírou pravděpodobnosti zde nebylo nikdy zř́izeno ani tržní místo, ani mýtná stanice. V úvahu připadá spíše tzv. latrán, čili opevněné předhradí napojené na hrad Tepenec, kde mohly probíhat provozně hospodářské činnosti. Pro další bádání bude klíčová analýza materiálu z jednotlivých objektů řazených do vrcholného středověku, což může přispět $\mathrm{k}$ přesnější interpretaci celého předhradí Tepence. ${ }^{23}$

\section{Poznámky}

1 V písemných pramenech se objevují další názvy referované lokality. Nacházíme ji také pod jménem Twingenberg, Twigenburch, Karlspurk nebo Karlsburg (k tomu Burian 1979a, 245-246; Čermák 2016, 72). Pro zjednodušení budeme v celém článku používat pouze název Tepenec, který se v literatuře vyskytuje nejčastěji.

2 Další starší zmínky o hradu v literatuře uvedl V. Burian (1979a, 248-249, pozn. 44).

3 Záchranné výzkumy zde proběhly v letech 1968-1971, 1971-1975, 1990, 1997-1999, 2007-2008, 2012, 2017, 2020.

4 Děkuji touto cestou PhDr. Vítu Dohnalovi, CSc. (1932-2020) za umožnění zpracovat středověký materiál z jeho výzkumu. Vyzvednuté nálezy jsou uloženy ve Vlastivědném muzeu v Olomouci pod př́r. č. 345/71, 323/72, 521/73, 335/74.

5 V. Dohnal v nálezové zprávě z výzkumu uvedl toto: „Pro hlavní zjištovací sondu, která se měla skládat ze čtverců $5 \times 5$ m řazených do pruhu za sebou, jsme vybrali okraj dobývacího prostoru, co možná nejdál od hradního jádra, abychom se vyhnuli terénu, který mohl být poškozen stavební či jinou činností v době středověkého využití lokality“ (Dohnal 1980a, 16).
6 V. Burian popsal vyzvednuté kachle jako „hrncové konkávní typy s kruhovým dnem a čtvercovým ústím, nepolévané“ (Burian 1971b, 67). Podle rozboru keramických nálezů pochází z prostoru hradního jádra celkem 29 zlomků nádobkových kachlů. Délka strany ústí se mohla pohybovat kolem 150 mm (Rodina 2001, 35, obr. 20: 5-70/3, 166-70/4, 1-68/15).

7 Fond uložen ve Státním okresním archivu Olomouc, inv. č. M 8-55.

8 Je vysoce pravděpodobné, že k daným plánkům existují také doprovodné fotografie. Ty jsou zřejmě součástí dosud nezpracovaného fondu Sbírka fotografií Ing. Josefa Kšíra uloženém ve Státním okresním archivu Olomouc.

9 Děkuji touto cestou PhDr. J. Doleželovi z Archeologického ústavu AV ČR Brno, v. v. i., za pomoc s interpretací této listiny.

10 Více k osobě Jindřicha z Nevojic viz Štěpán 2000.

11 Podobný měděný prsten byl nalezen v německém Lüneburgu. Má celkový průměr $21 \mathrm{~mm}$ a výšku $3 \mathrm{~mm}$. Nápis na prstenu je také proveden majuskulí, jen s tím rozdílem, že přepis je IASPAR : MELCHIOR: BAL (lücke) I. Na základě písma jej E. Ring datoval do poslední čtvrtiny 14. století. Nález spojoval s poutěmi (Ring 2013, 316).

$12 \mathrm{~V}$ rozhodnutí Ministerstva kultury ze dne 20. července 1971 stojí, že komise „...vzala v úvahu národohospodářský význam těžby v tomto kamenolomu, který potvrdil nadřízený resort provozovatele, $t j$. ministerstvo stavebnictví ČSR, $i$ okolnosti, že provozovatel těžby se předem zavázal plně respektovat zájmy kulturních orgánů $v$ daném prostoru, a doporučila rozkladu vyhovět. Rušim proto rozhodnutí ministerstva kultury čj. 34.985/68-II/2 ze dne 30. ř́jna 1968, jímž nebylo upuštěno od památkové ochrany zbytků středověkého hradu Tepence, okres Olomouc, a vydávám toto rozhodnutí: Ze shora uvedených důvodiu upouštím ve smyslu § 13 zákona č. 22/1958 Sb. od dalši památkové ochrany středověkého hradu Tepence a nově objeveného naleziště hallštatské kultury ve vymezeném dobývacím prostoru. "Rozhodnutí ministerstva je vloženo do nálezové zprávy z výzkumu provedeného v letech 1971-1975 jako příloha (Dohnal 1980a).

13 Lze připomenout nález kamenného sekeromlatu z hradu Křivoklátu, který byl uložený ve Zlaté Baště (Durdík 1997, 110).

14 Pro úplnost lze ještě uvést, že v literatuře je možné narazit na zmínky o nožce z kovové nádoby a zlomku předpokládané „obličejové“ nádoby (Cejpová 2003, 542, obr. 4: B; Čapek 2020, 233, obr. 6:3).

15 V této souvislosti lze připomenout, že T. Velímský považoval předhradí Tepence za nezdařené založení města, které nepřekročilo svou počáteční rozvojovou fázi (srov. Velímský 1992, 132). O nepovedeném založení města v případě předhradí hradu Tepence psali také V. Goš a J. Halama (Goš, Halama 2013, 213).

16 Výzkum v roce 1971 probíhal od 2. srpna do 3. září, v roce 1972 od 17. července do 11. záríí, v roce 1973 od 30. července do 10. srpna, v roce 1974 od 22. července do 23. srpna a $\mathrm{v}$ roce 1975 od 4. srpna do 29. srpna.

17 Výzkum měl zahrnovat ještě jeden čtverec (5/75), ale ten nebyl zkoumán, nebot' se nebylo možné dohodnout s lesním závodem ohledně pokácení vzrostlého buku ( $\mathrm{k}$ tomu Dohnal 1980a, 4-5).

18 U každého čtverce byl ponechán profil o mocnosti $50 \mathrm{~cm}$. Zatímco v prostoru hradiska dosahovala hloubka sondy od 40 do $60 \mathrm{~cm}$, tak v př́ípadě zkoumání valů činila až $160 \mathrm{~cm}$. Ke každému čtverci byla pořízena kresebná dokumentace půdorysu a všechny čtyři profily. 
19 To se však zdá málo pravděpodobné, nebot kameny byly nalezeny téměř ve všech čtvercích na výzkumu. $V$ daném př́ípadě nevytvářejí žádnou řadu či jasnější strukturu, kterou bychom mohli spojovat například s podezdívkou. Tento rozpor vynikne, srovnáme-li tento nadzemní objekt s objektem odkrytým na předhradí v roce 2007 , kde je kamenná podezdívka zcela nezpochybnitelná (srov. Vránová, Vrána 2016, 52, obr. 30).

20 S tímto materiálem pracuji také, i když podle uvedeného popisu se zdá, že nálezy pochází spíše z prostoru hradního jádra, popřípadě z jeho blízkosti.

21 Podle V. Dohnala došlo k totální skartaci nálezů pouze v př́ipadě první etapy výzkumu v roce 1971 (Dohnal 1980a, 5-6). Ze všech dalších sezón měl být jako neočíslovaný materiál uchován pro následující badání. Avšak podle tabulky s počty nálezů z jednotlivých čtverců v nálezové zprávě je zřejmé, že ze čtverců $1 / 72,2 / 72$ a 8/72 pochází pouze železná tyčinka (1/72) a šest středověkých střepů (8/72). K nim lze připočíst klíč a dveřní kování (srov. Dohnal 1980a, 34-35).

22 Ke středověkým nálezům řadil V. Dohnal drobnou bronzovou ozdobu v podobě kroužku o průměru $17 \mathrm{~mm}$ ze čtverce 11/74. Je však otázkou, zda tento nález spojovat se středověkým osídlením nebo využitím lokality v pozdní době bronzové až starší době železné. $\mathrm{Z}$ těchto důvodů s tímto nálezem v dalším textu nepracujeme.

23 Děkuji touto cestou za cenné rady kolegům PhDr. Pavlu Šlézarovi, Ph.D. z Národního památkového ústavu - územní odborné pracoviště Olomouc, Mgr. Vendule Vránové, Ph.D. z Archeologického centra Olomouc, Mgr. Petru Žákovskému, Ph.D. z Archeologického ústavu AV ČR Brno, v. v. i., a Mgr. Jiřímu Karlovi z Rýmařova.

\section{Literatura}

Anonym 1900: Naše vyobrazení. Zarostlý hrad Tepenec v rozvalinách. Náš Domov 60, 66.

Bartoš, J., Kovářová, S. 1999: Dějiny obce Jivová. Jívová: Obecní úřad Jívová.

Belcredi, L. 2006: Bystřrec: O založení, životě a zániku středověké vsi. Archeologický výzkum zaniklé středověké vsi na Drahanské vrchovinĕ 1975-2005. Brno: Muzejní a vlastivědná společnost v Brně, Moravské zemské muzeum.

Bláha, J. 1982: Archeologický průzkum v Olomouci. Staveniště obchodního domu Prior. Objekty XVII/73 a IV/73. (Keramika). Archeologické prameny k dějinám olomoucké oblasti I/1. Olomouc: Okresní středisko státní památkové péče a ochrany př́rody.

Bláha, J. 1987: Archeologický průzkum v Olomouci. Staveniště obchodního domu Prior. Objekty 5/78, 59/79 a 68/79. (Keramika). Archeologické prameny k dějinám olomoucké oblasti I/2. Olomouc: Okresní středisko státní památkové péče a ochrany prírody.

Bláha, J. 1995: Olomouc - př́íspěvek ke kulturní historii pozdně stř̌edověkých měst. In: K. Wachowski (red.): Kultura średniowiecznego Ślaska i Czech. „Rewolucja“ XIII wieku. Kultura sredniowiecznego Sląska i Czech. Miedzynarodowe Sympozjum 3. Wrocław: Uniwersytet Wrocławski. Centrum Badań Śląskoznawczych i Bohemistycznych, 29-39.

Bláha, J. 1999: Archeologické poznatky ke stavební konstrukci nejstarších měštanských domů v Olomouci. Archaeologia historica 24, 189-213. Dostupné také z: http://hdl.handle.net/11222.digilib/140332.

Bláha, J., Sedláčková, H. 1998: Slavnostní keramika. In: H. Sedláčková (ed.): Sklo, slavnostní keramika a kachle. Renesanční Olomouc v archeologických nálezech. Archeologické výzkumy Památkového ústavu v Olomouci 1973-1996. Olomouc: Památkový ústav v Olomouci, Spolek pro podporu historicko-archeologických výzkumů na Olomoucku, 15-18.

Bolina, P. 2004a: I Karel IV. se mohl zmýlit. Vlastivědný věstník moravský LXII(2), 169-176.

Bolina, P. 2004b: „Per transversum montis Scalicze“ - k interpretaci pozůstatků starých cest na katastru Dolan u Olomouce ve světle rozhraničovací dohody dolanského kláštera a olomoucké kapituly z roku 1404. Archaeologia historica 29, 93-118. Dostupné také z: http://hdl.handle.net/11222.digilib/140566.

Brůnová, K. 2004: Hrad Hluboký, k. ú. Město Libavá, okr. Olomouc. Vlastivědný věstník moravský LVI(1), 46-55.

Březinová, H. 2007: Textilní výroba v českých zemích ve 13.-15. století: poznání textilní produkce na základě archeologických nálezů. Dissertationes archaeologicae Brunenses/Pragensesque 2. Praha: Ústav pro pravěk a ranou dobu dějinnou, Filozofická fakulta, Univerzita Karlova. Dostupné také z: https://digilib.phil.muni.cz/handle/11222.digilib/127388.

Burian, V. 1958: Keramika z nálezů mincí. Archeologické rozhledy X(2), 260-262.

Burian, V. 1964: Nálezy ze středověkého objektu v Dolanech (výzkum 1962). Práce odboru společenských věd Vlastivědného ústavu v Olomouci 3. Olomouc: Vlastivědný ústav.

Burian, V. 1970: Historickoarcheologický výzkum hradu Tepence (Jívová, okres Olomouc) v letech 1968-1969. Zprávy Vlastivědného ústavu v Olomouci 147, 2-10.

Burian, V. 1971a: Třetí archeologická kampaň na hradě Tepenci (Jívová, okres Olomouc). Zprávy Vlastivědného ústavu v Olomouci 150, 2-6.

Burian, V. 1971b: Výzkum hradu Tepence (obec Jívová) roku 1970 (okr. Olomouc). Přehled výzkumů 1971, 65-68, 129-133. Dostupné také z: https://www.arub.cz/magazine/pv-15/.

Burian, V. 1972a: Historickoarcheologický výzkum hradu Tepence roku 1971. Zprávy Vlastivědného ústavu v Olomouci 156, 7-9.

Burian, V. 1972b: Nález středověké keramiky v Olomouci-Ostružnické ulici (okr. Olomouc). Přehled výzkumů 1971, 107, 247. Dostupné také z: https://www.arub.cz/magazine/pv-16/.

Burian, V. 1974: K moravským nálezům kostěného obložení sochy kuše ze 14. a 15. století. Zprávy Vlastivědného ústavu v Olomouci 170, 16-19.

Burian, V. 1975: Příspěvek k nejstarší historii olomouckého Předhradí (Středověké nálezy v býv. Mariánské ulici). Vlastivědný věstník moravský XXVII(3), 269-282.

Burian, V. 1979a: Tepenec - moravský hrad markraběte Karla. Umění XXVII(3), 245-249.

Burian, V. 1979b: Rozbor nálezů hřebů z hradu Tepence u Jívové a kartouzy v Dolanech (1340-1425). Zprávy Krajského vlastivědného muzea $v$ Olomouci 202, 21-31.

Burian, V. 1980: Ojedinělé nálezy na hradisku Tepenci u Jívové (okr. Olomouc). Přehled výzkumů 1977, 112-113. Dostupné také z: https://www.arub.cz/magazine/pv-22/.

Burian, V. 1981a: Nálezy na hradisku Tepenci v roce 1979 (Jívová, okr. Olomouc). Přehled výzkumů 1979, 53. Dostupné také z: https://www.arub.cz/magazine/pv-24/.

Burian, V. 1981b: Nálezy jezdeckých třmenů z období 1340-1425 na hradě Tepenci a v Dolanské Kartouze. Zprávy Krajského vlastivědného muzea v Olomouci 212, 25-28.

Burian, V. 1982: Jezdecké ostruhy posádek na Tepenci a Kartouzce (1340-1425). Zprávy Krajského vlastivědného muzea v Olomouci 218 , 23-29.

Burian, V. 1984: Rozbor nálezů podkov z hradu Tepence a husitského opevnění Kartouzka (1340-1425). Zprávy Krajského vlastivědného muzea v Olomouci 228, 12-17.

Burian, V. 1985a: Projektily z těžkých palných a vrhacích zbraní z Tepence a Dolan. Zprávy Krajského vlastivědného muzea $v$ Olomouci 234, 20-25. 
Burian, V. 1985b: Nálezy hřebelců k ošetřování koní z Tepence a Dolan a jejich středověké analogie. Zprávy Krajského vlastivědného muzea $v$ Olomouci 236, 26-27.

Burian, V. 1988: Kostařské výrobky v nálezech z hradu Tepence a dolanské Kartouzy (1340-1425). In: V. Frolec (ed.): Rodná země. Sborník k 100. výročí muzejní a vlastivědné společnosti v Brně a $k$ 60. narozeninám PhDr. Vladimíra Nekudy, CSc. Brno: Muzejní a vlastivědná společnost v Brně, 305-308.

Burian, V., Opravil, E. 1970: Středověké nálezy z Olomouce. Archeologické rozhledy XXII, 148-158, 253-256.

CDB II: Codex diplomaticus et epistolaris regni Bohemiae (1198-1230). Friedrich, G. (ed.): Pragae 1912.

CDB V/2: Codex diplomaticus et epistolaris regni Bohemiae (1267-1278). J. Šebánek, S. Dušková (edd.): Pragae 1981.

CDM VII: Codex diplomaticus et epistolaris Moraviae (1334-1345). Chytil, J. (ed.). Brünn 1858.

CDM IX: Codex diplomaticus et epistolaris Moraviae (1356-1366). Brandl, V. (ed.). Brünn 1875.

CDM X: Codex diplomaticus et epistolaris Moraviae (1357-1375). Brandl, V. (ed.). Brünn 1878.

CDM XIII: Codex diplomaticus et epistolaris Moraviae (1400-1407). Brandl, V. (ed.). Brünn 1897.

Cejpová, M. 2003: Kovová trojnožka z hradu Trosky a některé její analogie. Archaeologia historica 28, 539-546. Dostupné také z: https://digilib.phil.muni.cz/handle/11222.digilib/140536.

Čapek, L. 2020: Zlomek obličejové nádoby z Českých Budějovic v kontextu středověkých a novověkých picích nádob s antropomorfní výzdobou. Archeologické výzkumy v jižních Čechách 33, 227-246.

Čapek, L., Těsnohlídková, K., Slavíček, K., Všianský, D., Pracný, P. 2018: Technologie výroby a archeometrické studium středověké keramiky. Plzeň, Brno: Západočeská univerzita, Masarykova univerzita.

Čermák, M. 2016: Karel IV. a Olomouc. Střední Morava 41, 72-75.

Čižmář, Z., Šmíd, M. 2000: Vývoj Prostějova v archeologických a historických pramenech v období 10.-16. století. Archaeologia historica 25, 77-102. Dostupné také z: http://hdl.handle.net/11222.digilib/140367.

Dehnerová, H., Šlézar, P. 2015: Středověký kartouzský klášter „Vallis Josaphat“. In: M. Tomášek a kol.: 100 zajímavých archeologických lokalit Čech, Moravy a Slezska. Praha: Národní památkový ústav, 77-80.

Dehnerová, H., Šlézar, P., Zatloukal, R. 2007: Doklady středověké řemeslné zručnosti a lidové kultury našich předků z archeologických výzkumů na Olomoucku. In: I. M. Kubešová (ed.): Památky, řemesla a lidová kultura. Sborník př́spěvků ze seminář konaného u př́ležitosti Dnů evropského kulturního dědictví, Olomouc 6.-8. 9. 2007. Olomouc: Statutární město Olomouc, 35-46.

Dehnerová, H., Večeřa, P. 2007: Hrad Šternberk. Rkp. nálezové zprávy, č. j. MTX200704047. [cit.2021-10-17]. Uloženo: Archiv nálezových zpráv Archeologického ústavu AV ČR, Brno, v. v. i. Dostupné také z: Digitální archiv Archeologické mapy České republiky https://digiarchiv.aiscr.cz/id/M-TX-200704047.

Dohnal, V. 1972: Zjištovací sondáž na Tepenci (katastr Jívová) pravěká část (okr. Olomouc). Přehled výzkumů 1971, 62-65, 205-209. Dostupné také z: https://www.arub.cz/magazine/pv-16/.

Dohnal, V. 1974: Výzkum hradiska z pozdní doby bronzové na Tepenci obec Jívová (okr. Olomouc). Přehled výzkumů 1973, 34-36, 160-162. Dostupné také z: https://www.arub.cz/magazine/pv-18/.

Dohnal, V. 1975: Výzkum na pozdněbronzovém hradisku na Tepenci obec Jívová (okr. Olomouc). Přehled výzkumů 1974, 26-27. Dostupné také z: https://www.arub.cz/magazine/pv-19/.

Dohnal, V. 1977: Dokončení záchranného výzkumu na pozdněbronzovém hradisku na kopci Tepenec obec Jívová (okr. Olomouc). Přehled výzkumů 1975, 21-22, tab. 4. Dostupné také z: https://www.arub.cz/magazine/pv-20/.

Dohnal, V. 1980a: Jívová „Tepenec“ 1971-1975, I. díl. Rkp. nálezové zprávy, č. j. MTX199100877. [cit. 2021-10-17]. Uloženo: Archiv nálezových zpráv Archeologického ústavu AV ČR, Brno, v. v. i. Dostupné také z: Digitální archiv Archeologické mapy České republiky https://digiarchiv.aiscr.cz/id/M-TX-199100877.

Dohnal, V. 1980b: Jívová „Tepenec“ 1971-1975, II. díl. Rkp. nálezové zprávy, č. j. MTX199100877. [cit. 2021-10-17]. Uloženo: Archiv nálezových zpráv Archeologického ústavu AV ČR, Brno, v. v. i. Dostupné také z: Digitální archiv Archeologické mapy České republiky https://digiarchiv.aiscr.cz/id/M-TX-199100877.

Dohnal, V. 1980c: Jívová „Tepenec“ 1971-1975, III. díl. Rkp. nálezové zprávy, č. j. MTX199100877. [cit. 2021-10-17]. Uloženo: Archiv nálezových zpráv Archeologického ústavu AV ČR, Brno, v. v. i. Dostupné také z: Digitální archiv Archeologické mapy České republiky https://digiarchiv.aiscr.cz/id/M-TX-199100877.

Dohnal, V. 1980d: Jívová „Tepenec“ 1971-1975, IV. díl. Rkp. nálezové zprávy, č. j. MTX199100877. [cit. 2021-10-17]. Uloženo: Archiv nálezových zpráv Archeologického ústavu AV ČR, Brno, v. v. i. Dostupné také z: Digitální archiv Archeologické mapy České republiky https://digiarchiv.aiscr.cz/id/M-TX-199100877.

Dohnal, V. 1988: Opevněná sídliště z doby popelnicových polí na Moravě. Studie muzea Kroměřížska '88. Kroměříž: Muzeum Kroměřížska.

Dohnal, V. 1991: Jívová „Tepenec“, sezóna výzkumu 1990. Rkp. nálezové zprávy, č. j. MTX199100876. [cit. 2021-10-17]. Uloženo: Archiv nálezových zpráv Archeologického ústavu AV ČR, Brno, v. v. i. Dostupné také z: Digitální archiv Archeologické mapy České republiky https://digiarchiv.aiscr.cz/id/M-TX-199100876.

Doležel, J. 2008: Městisko: zaniklá městská lokace 13. století na Prostějovsku. Archeologické rozhledy LX(3), 459-508.

Durdík, T. 1997: „Hromový klín“ z hradu Křivoklátu. In: Sborník Společnosti prátel starožitností 1. 2. upr. vyd. Praha: Společnost přátel starožitností, 107-110.

Durdík, T. 2012: Opevněná hradní městečka v Čechách. Archaeologia historica 37(1), 175-187. Dostupné také z: http://hdl.handle.net/11222.digilib/128249.

Durdík, T., Bolina, P. 2001: Středověké hrady v Čechách a na Moravě. Praha: Argo.

Faltýnek, K. 2012: Předběžná zpráva o výsledcích archeologických dohledů prováděných $\mathrm{v}$ Chořelicích a Litovli a tak trochu o smyslu archeologie vůbec. In: R. Nejman (ed.): Ročenka Muzejní společnosti Litovelska 2011. Zajímavosti z Litovelska. Olomouc: Muzejní společnost Litovelska, 77-110.

Flejberk, Z. 1965: Kronika Archeologického / historického kroužku při okresním museu a archivu ve Šternberku od roku 1962. Šternberk.

Fojtík, P. 2015: Keramický cášský roh ze zaniklé středověké vsi na k. ú. Kralice na Hané, okr. Prostějov, střední Morava. Archeologické rozhledy LXVII(2), 287-298.

Frait, R. 2001: Kovové předměty z kartuziánského kláštera v Dolanech. Rkp. bakalářské diplomové práce. Slezská univerzita v Opavě. Filozofická fakulta. Uloženo: Filozofická fakulta Slezské univerzity v Opavě.

Frolík, J., Musil, J. 2013: Několik poznámek k obléhání hradu Lichnice v letech 1428-1429. Chrudimský vlastivědný sborník 17, 125-214.

Goš, V. 1980: Keramika doby husitské na severní Moravě. Archaeologia historica 5, 369-374. Dostupné také z: http://hdl.handle.net/11222.digilib/139325.

Goš, V. 2007: Loštice. Město středověkých hrnčírůu. Opava: Slezská univerzita v Opavě.

Goš, V. 2016: Nálezový soubor z Nového hradu u Hanušovic. Etuda z archeologie všedního dne. Pravěk Nová řada 24, 265-294. 
Goš, V., Halama, J. 2013: Šumperk, ulice Na Hradbách. Provizorium či lehká dřevohliněná stavba ze 13. století, malé zamyšlení nad velkým problémem. Archaeologia historica 38(1), 203-217. Dostupné také z: http://hdl.handle.net/11222.digilib/128316.

Goš, V., Karel, J. 1992: Tvrz v Rýmařově (okr. Bruntál). Archaeologia historica 17, 225-232. Dostupné také z: http://hdl.handle.net/11222.digilib/139994.

Goš, V., Karel, J. 1999: Hrad Strálek u Rýmařova. Střední Morava 8, 105-114.

Goš, V., Novák, J. 1976: Počátky výroby loštické keramiky. Archeologické rozhledy XXVIII(4), 399-404.

Goš, V., Novák, J., Karel, J. 1975: Nadzemní objekt v Rýmařově Hrádku. Časopis Slezského muzea, série B XXIV(2) 97-105.

Goš, V., Novák, J., Karel, J. 1985: Počátky osídlení Rýmařova. Památky archeologické LXXVI, 184-227.

Gruntová, L. 2015: Petroarcheologická analýza středověké keramiky z hradu Tepence. Rkp. bakalářské diplomové práce. Univerzita Palackého v Olomouci. Př́rodovědecká fakulta. Uloženo: Knihovna Př́rodovědecké fakulty Univerzity Palackého v Olomouci.

Hložek, J. 2016: Několik poznámek k podhradním aglomeracím v jižních Čechách - tzv. latránům. In. D. Kovář (ed.): Počátky měst a městeček v jižních Čechách. Sborník př́spěvkủ $k$ dějinám urbanizace jihočeského regionu, 2. část. Jihočeský sborník historický Supplementum 7. České Budějovice: Jihočeské muzeum v Českých Budějovicích, 295-313.

Hlubek, L. 2010: Soubor militarií z rýmařovské tvrze. Castellologica bohemica 12, 489-500.

Hlubek, L. 2013: Archeologické nálezy z hradu Rabštejna (okr. Šumperk). Acta Musei Moraviae, Scientiae sociales XCVIII(1), 125-143.

Hlubek, L. 2017: Keramika z hradu Hlubokého. Rkp. analýzy keramiky z hradu Hlubokého. Uloženo: Vlastivědné muzeum v Olomouci.

Hlubek, L. 2018: Loštice (okr. Šumperk). Přehled výzkumů 59(2), 252-254. Dostupné také z: https://www.arub.cz/magazine/pv-59-2/.

Hlubek, L. 2019: Vývoj raně stř̌edověkého osídlení na Šternbersku. Zprávy Vlastivědného muzea v Olomouci 318, 5-23.

Hlubek, L. 2020a: Neznámá kolekce středověkých nálezů ulice 8. května čp. 504 v Olomouci. Zprávy Vlastivědného muzea $v$ Olomouci 320, 19-36.

Hlubek, L. 2020b: Zaniklá stř̌edověká ves Prlov (okr. Olomouc). Střední Morava 49, 85-91.

Hlubek, L., Schenk, Z. 2020: Hlubočky (okr. Olomouc). Přehled výzkumů 61(2), 150-151. Dostupné také z: https://www.arub.cz/magazine/pv-61-2/.

Kalábek, M. 2005: Archeologické nálezy a lokality na katastru Dolan. Střední Morava 20, 55-72.

Kalábek, M., Tymonová, M. 1998: Nálezová zpráva ze záchranného archeologického výzkumu Tepenec 1997. Rkp. nálezové zprávy, č. j. MTX200101393. [cit. 2021-10-17]. Uloženo: Archiv nálezových zpráv Archeologického ústavu AV ČR, Brno, v. v. i. Dostupné také z: Digitální archiv Archeologické mapy České republiky https://digiarchiv.aiscr.cz/id/M-TX-200101393.

Kalábková, P., Hlava, M., Šlézar, P. 2015: Př́běhy uničovské archeologie. Uničov: Město Uničov.

Kaźmierczyk, J. 1978: Podkowy na Śląsku w X-XIV wieku. Studia z dziejów kultury materialnej. Prace Komisji Nauk Humanistycznych 9. Wrocław: Zakład Narodowy im. Ossolińskich.

Koudela, M., Šindlářová, I. 2012: Paměti obce Dolany. Dolany: Obec Dolany.

Kouřil, P. 1988: Hrad Vartnov a jeho postavení ve vývoji hradů na Opavsku. In: V. Frolec (ed.): Rodná země. Sborník k 100. výročí muzejní a vlastivědné společnosti v Brně a $k$ 60. narozeninám PhDr. Vladimíra Nekudy, CSc. Brno: Muzejní a vlastivědná společnost v Brně, 285-304.
Kouřil, P., Prix, D., Wihoda, M. 2000: Hrady českého Slezska. Brno, Opava: Archeologický ústav AV ČR.

Krajíc, R. 2003: Sezimovo Ústí. Archeologie středověkého města 3. Kovárna v Sezimově Ústí a analýza výrobků ze železa, Díl I. Praha: Archeologický ústav AV ČR.

Kuča, K. 2000: Města a městečka v Čechách, na Moravě a ve Slezsku. 2. díl, H-Kole. Praha: Libri.

Martínek, J., Vránová, V. 2018: Nové hradisko „Teplá díra“ na katastru Dolan. In: M. Kršková, J. Peška (eds.): Ročenka 2017. Olomouc: Archeologické centrum Olomouc, 112-119.

Měchurová, Z. 1995: Železné předměty ze zaniklé středověké vsi Konůvky na Slavkovsku (okres Vyškov). Časopis Moravského muzea, vědy společenské LXXX, 141-197.

Měchurová, Z. 2013: Drobné středověké a novověké nálezy z Ostravy ve sbírkách Slezského zemského muzea v Opavě. Časopis Slezského zemského muzea, série B 62(2-3), 185-198.

Měřínský, Z. 1969: Přehled typů loštické keramiky, jejich vývoj a datování. Vlastivědný věstník moravský XXI(2-3), 89-105.

Měřínský, Z. 2007: Hrad Rokštejn. Dějiny, stavební vývoj a výsledky čtvrtstoletí archeologického výzkumu 1981-2006. Brno: Ústav archeologie a muzeologie Filozofické fakulty Masarykovy univerzity v Brně.

Mezník, J. 2001: Lucemburská Morava 1310-1423. Praha: Nakladatelství Lidové Noviny.

Michna, P. 1974: Archeologické nálezy z výzkumu hradu Melic na Vyškovsku. Vlastivědný věstník moravský XXVI(1), 61-78.

Michna, P. 1980: Dvě sídlištní stavby z počátku lokačního Uničova. (Příspěvek do diskuze $\mathrm{k}$ otázce zemnic ve městech a vesnicích 13. století). Vlastivědný věstník moravský XXXII(2), 161-186.

Michna, P. J. 1982: Ke stavebním dějinám stř̌edověkých domů v Olomouci. (Archeologický průzkum dvou městišt v Barvířské ulici). Sborník Památkové péče v Severomoravském kraji 5, 179-241.

Michna, P. 1988: K poznání zahloubených obydlí doby velké kolonizace. In: I. Frolec (ed.): Rodná země. Sborník k 100. výročí Muzejní a vlastivědné společnosti v Brně a $k$ 60. narozeninám PhDr. Vladimíra Nekudy, CSc. Brno: Muzejní a vlastivědná společnost v Brně, 222-284.

Musil, J. 2019: Hrad Strádov s tábořištěm bojové družiny? In: P. Elbel, L. Jan, J. Jurok a kol.: Z počátkư husitské revoluce. Brno: Matice moravská, 64-86.

Nekuda, R. 1980: Korpus středověké keramiky datované mincemi z Moravy a Slezska. Archaeologia historica 5, 389-450. Dostupné také z: http://hdl.handle.net/11222.digilib/139328.

Nekuda, V. 2007: Středověká vesnice na Moravě. Brno: Muzejní a vlastivědná společnost.

Nekuda, V., Reichertová, K. 1968: Středověká keramika v Čechách a na Moravě. Brno Moravské museum.

Novák, J. 2020: Kopcovité útvary z hlíny a kamene jako prostředek $\mathrm{k}$ vymezení hranic území v písemných pramenech kláštera Hradisko u Olomouce. Archaeologia historica 45(1), 255-277. Dostupné také z: http://hdl.handle.net/11222.digilib/142967.

Novotný, B. 1970: Nálezy ze zaniklého hradu Tepence (okr. Olomouc). Přehled výzkumů 1968, 63-64. Dostupné také z: https://www.arub.cz/magazine/pv-13/.

Opravil, E. 1980: Dřeviny z moravských archeologických nálezů II. Zprávy Krajského vlastivědného muzea v Olomouci 205, 23-29.

Pinkava, V. 1927: Hrady, zámky a tvrze moravské. I. svazek, Severní Morava (Olomúcko). Brno: Nákladem turistického obzoru.

Plaček, M. 2000: K vývoji hradů v období moravské lucemburské sekundogenitury. In: J. Vaněk (ed.): Moravští Lucemburkové 1350-1411. Sborník prací Muzea města Brna. Forum Brunense. Brno: Muzeum města Brna, 189-222.

Plaček, M. 2001: Ilustrovaná encyklopedie moravských hradů, hrádků a tvrzí. Praha: Libri. 
Prasek, V. 1883: Př́íspěvky k dějinám zapomenutých hradů a tvrzí 5. Tepenec čili Karlsburk. Komenský 11, 72-75.

Prečanová, V. 1999: Odpadní jímka $z$ domu čp. 7 na Dolním náměstí $v$ Olomouci. Rkp. bakalářské diplomové práce. Slezská univerzita v Opavě. Filozofická fakulta. Uloženo: Filozofická fakulta Slezské univerzity v Opavě.

Procházka, R. 1995: Keramik des 14.-14./15. Jahrhunderts aus Brno und Boskovice. Ein Beitrag zur Regionalisierung der mittelalterlichen Keramik in Mähren. In: W. Endres (ed.): Beiträge des 26. Internationalen Hafnerei - Symposiums, Soest 5. 10.-9. 10. 1993. Denkmalpflege und Forschung in Westfalen 32. Bonn: Habelt, 113-124.

Procházka, R. 1996: Brněnská stolní a kuchyňská keramika 2. poloviny 14. století - počátku 15. století. Pravěk Nová řada 4, 323-344.

Procházka, R. 2007: Archeologie a poznání moravských a slezských měst. Archaeologia historica 32, 37-80. Dostupné také z: http://hdl.handle.net/11222.digilib/140700.

Procházka, R., Žákovský, P. 2019: K současnému stavu poznání gotické fáze hradu Pustiměř (Zelená hora u Radslavic) - výpověd' archeologie. In: M. Dejmal, L. Jan, R. Procházka (eds.): Na hradech a tvrzích. Miroslavu Plačkovi k 75. narozeninám jeho přátelé a žáci. Praha: Nakladatelství Lidové noviny, 203-231.

Procházková, P., Kalábek, M. 2000: Jívová (okr. Olomouc). Přehled výzkumu 41 (1999), 167-168. Dostupné také z: https://www.arub.cz/magazine/pv-41/.

Prokisch, E. 1941: Das Städtchen Giebau. Hainfeld-Giebau: Eigenvlg. d. Gemeinde Giebau.

Protivanovský, J. 1877: O tvrzi neb hradu Tepenci blíže Jívavy. Koleda II(5), 78, 94.

Ring, E. 2013: Pilger in Lüneburg. In: S. Kleingärtner, U. Müller, J. Scheschkewitz (Hrsg.): Kulturwandel im Spannungsfeld von Tradition und Innovation. Festschrift für Michael Müller-Wille. Neumünster: Wachholtz Verlag Neumünster, 313-320.

Rodina, J. 2001: Středověká keramika z hradu Tepenec, $k$. ú. Jívová. Rkp. bakalářské diplomové práce. Slezská univerzita v Opavě. Filozofická fakulta. Uloženo: Filozofická fakulta Slezské univerzity v Opavě.

Rusó, A., Smetana, J. 1994: Zaniklé městečko pod Házmburkem (K otázce tzv. latránů a opevněných podhradí). Archaeologia historica 19, 319-336. Dostupné také z: http://hdl.handle.net/11222.digilib/140101.

Sedláčková, H. 2001: Gotické sklo na stř̌ední a severní Moravě v archeologických nálezech. Archaeologia historica 26, 411-428. Dostupné také z: http://hdl.handle.net/11222.digilib/140433.

Sedláčková, L. 2020: Proměny vybavení brněnské měštanské kuchyně vrcholného a pozdního středověku [online]. Rkp. disertační práce. Masarykova univerzita. Filozofická fakulta. Uloženo: Archiv závěrečných prací Masarykovy univerzity. [cit. 2021-10-12]. Dostupné z: https://is.muni.cz/th/rlnud/.

Serdon, V. 2005: Armes du diable. Arcs et arbalètes au moyen âge. Rennes: Presses Universitaire de Rennes.

Stief, W. 1896: Topographie des politischen Bezirkes Sternberg in Mähren. Sternberk: Pialek Verlag.

Świętosławski, W. 1990: Strzemiona średniowieczne z ziem Polski. Łódź: Polska Akademia Nauk, Instytut Historii Kultury Materialnej.

Šindler, J. 1927-1928: Z dějin Tepence. Vlastivědný sborník pro mládež župy olomoucké 6/1927-1928, př́loha Olomoucko, 7-9.

Šlézar, P. 2002: Středověká kolonizace vrchovin okresu Prostějov. Rkp. magisterské diplomové práce. Západočeská univerzita v Plzni. Filozofická fakulta. Uloženo: Filozofická fakulta Západočeské univerzity v Plzni.

Šlézar, P. 2008: Archeologický výzkum v suterénu budovy Městského klubu v Litovli. Vlastivědný věstník moravský LX(2), 167-183.
Šlézar, P. 2017: Archeologický výzkum u kostela Panny Marie Sněžné. Příspěvek k problematice počátků opevnění a církevních staveb na olomouckém Předhradí. Přehled výzkumů 58(2), 97-127. Dostupné také z: https://www.arub.cz/prehled-vydanych-cisel/ PV-58-2_Slezar.pdf.

Šlézar, P., Faltýnek, K. 2019: Románský kostel sv. Prokopa v Lošticích. Př́spěvek k počátkům moravské šlechty. Přehled výzkumů 60(2), 161-199. Dostupné také z: https://www.arub.cz/prehledvydanych-cisel/pv_60_2_slezar_faltynek.pdf.

Štěpán, V. 2000: Jindřich z Nevojic. Osudy moravského zemana v předvečer husitské revoluce. Vlastivědný věstník moravský LII(1), 3-16.

Štěpán, V. 2002: Moravský markrabě Jošt (1354-1411). Brno: Matice moravská.

Tejkalová, Z. 2017: Geofyzikální výzkum hradiska Tepenec. Rkp. bakalářské diplomové práce. Univerzita Palackého v Olomouci. Př́rodovědecká fakulta. Uloženo: Přírodovědecká fakulta Univerzity Palackého v Olomouci.

Trňáčková, Z. 1963: Př́růstky archeologického oddělení Vlastivědného ústavu v Olomouci v roce 1962. Zprávy Vlastivědného ústavu v Olomouci 110, 17.

Tymonová, M. 2002: Středověký hrad Tepenec u Jívové a jeho fortifikační systém. Archaeologia historica 27, 215-228. Dostupné také z: http://hdl.handle.net/11222.digilib/140465.

Tymonová, M. 2003: Kachlová kamna z Náměště na Hané. Archaeologia historica 28, 575-590. Dostupné také z: http://hdl.handle.net/11222.digilib/140540.

Tymonová, M., Kalábek, M. 1999: Dosavadní výsledky archeologického výzkumu lokality Tepenec na katastru obce Jívové (okr. Olomouc). Střední Morava 6, 89-95.

Unger, J. 1974: Archeologické nálezy z výzkumu hradu Melic na Vyškovsku (železné předměty). Vlastivědný věstník moravský XXVI(2), 194-201.

Unger, J. 1999: Život na lelekovickém hradě ve 14. století. Antropologická sociokulturní studie. Brno: Nakladatelství Georgetown.

Vágner, M., Milo, P. 2020: Zpráva o geofyzikální prospekci. Hrad Tepenec. Rkp. nálezové zprávy. Uloženo: Archiv nálezových zpráv Národního památkového ústavu, uzemní odborné pracoviště Olomouc.

Velímský, T. 1992: Zur problematik der Stadtgründung des 13. Jahrhunderts in der Kynšperk nad Ohří (Königsberg). Památky archeologické LXXXIII(1), 105-148.

Vích, D. 2015: Relikt dřevěné stavby z počátku 14. století v Litomyšli. Archeologie východních Čech 9, 205-222.

Vránová, V. 2014: Jívová (okr. Olomouc). Přehled výzkumů 54(2), 200-201. Dostupné také z: https://www.arub.cz/magazine/pv-54-2/.

Vránová, V. 2018: Jívová (okr. Olomouc). Přehled výzkumů 59(2), 247-248. Dostupné také z: https://www.arub.cz/magazine/pv-59-2/.

Vránová, V. 2021: Jívová (okr. Olomouc). Přehled výzkumů 62(1), 239-240. Dostupné také z: https://www.arub.cz/magazine/pv-62-1/.

Vránová, V., Rybníček, M., Kolář, T. 2010: Evaluation of results from the examination of timber casing of an underground cistern in Tepenec Castle. Interdisciplinaria Archaeologica. Natural Sciences in Archaeology 1(1-2), 61-66.

Vránová, V., Vrána, J. 2005: Jívová - Tepenec. Pravěké hradisko a Karlův hrad. Archeologické památky střední Moravy 9. Olomouc: Archeologické centrum Olomouc.

Vránová, V., Vrána, J. 2008: Olověné projektily z hradu Tepence. Castellologica bohemica 11, 457-460.

Vránová, V., Vrána, J. 2012a: Nálezy podkov z hradu Tepence. Archaeologia historica 37(2), 733-746. Dostupné také z: http://hdl.handle.net/11222.digilib/128290.

Vránová, V., Vrána, J. 2012b: Nálezy ostruh z hradu Tepence z archeologických výzkumů z let 1997, 1998, 2007-2008. In: J. Doležel, M. Wihoda (eds.): Mezi raným a vrcholným 
středověkem. Pavlu Kouřilovi k šedesátým narozeninám přátelé kolegové a žáci. Brno: Archeologický ústav AV ČR, Brno, 653-664.

Vránová, V., Vrána, J. 2013: Shrnutí výsledků archeologického průzkumu studny na hradě Tepenec. Časopis Slezského zemského muzea, série B 62(2-3), 289-299.

Vránová, V., Vrána, J. 2016: Tepenec. Karli̊v hrad-mizející památka. Archeologické památky střední Moravy 21. Olomouc: Archeologické centrum Olomouc.

Vránová, V., Vrána, J., Moník, M. 2014: Doklady zpracování železa na hradě Tepenci. Archaeologia historica 39(2), 639-647. Dostupné také z: http://hdl.handle.net/11222.digilib/130332.

Wolny, G. 1846: Die Markgrafschaft Mähren. Topographisch, statistisch und historisch geschildert. V. Band. Ollmützer Kreis. Brünn: Selbstverlag des Verfassers.

Zimmermann, B. 2000: Mittelalterliche Geschossspitzen. Kulturhistorische, archäologische und archäometallurgische Untersuchungen. Schweizer Beiträge zur Kulturgeschichte und Archäologie des Mittelalters 26. Basel: Schweizerischer Burgenverein.

Žákovský, P. 2006: Analýza železných předmětů z Ježova hradu u Stínavy. Rkp. magisterské práce. Masarykova univerzita. Filozofická fakulta. Uloženo: Archiv závěrečných prací Masarykovy univerzity. Dostupné také z: https://is.muni.cz/th/xk45f/.

Žákovský, P. 2014: Tesáky a problematika jednosečných zbraní střredověku a raného novověku. Katalog [online]. Rkp. disertační práce. Masarykova univerzita. Filozofická fakulta. Uloženo: Archiv závěrečných prací Masarykovy univerzity [cit. 2021-10-12]. Dostupné z: https://is.muni.cz/th/brvjl/.

Žákovský, P., Schenk, Z. 2017: Středověké a raně novověké zbraně Přrovska. Zbraně a zbroj od kolapsu Velké Moravy do konce třicetileté války. Přerov: Muzeum Komenského v Přerově.

\section{Summary}

The present study assesses the rescue excavations at Tepenec Castle. The castle was built during the 1330s and 1340s by order of the Margrave of Moravia, Charles IV, who had bought Tepenec Hill and its vicinity from the Bishop of Olomouc, Jan Volek, for this purpose. He wanted the castle to protect the Jívová Road connecting the Olomouc region with Silesia. The castle ceased to exist in the early 15 th century when it was besieged by an army led by governor of the castle Jakub Štěně of Běliny.

The fortification consisted of the castle core and an extensive outer bailey where an Urnfield culture hillfort had been previously located. Since the 1960s, the site has been gradually disappearing due to the activity in a nearby stone quarry. This is why rescue excavations have been underway at Tepenec Castle from 1968 to this day. This text focuses on the assessment of the medieval occupation of the outer bailey excavated in 1971-1975 by V. Dohnal.
The head of the excavation first laid out a $30 \mathrm{~m}$ long and $1 \mathrm{~m}$ wide test pit in the outer bailey area. The following year, he opened the main trench, which intersected the whole fortified area from the northwest to the southeast. A total area of $855 \mathrm{sqm}$ was examined. Even though the research focused on addressing issues connected with the prehistoric occupation at the site, V. Dohnal succeeded in partially examining two above-ground structures dated to the 14th century. The first was situated close to the northern side, not far from the course of the fortification. A corner of the structure was uncovered, forming a $75^{\circ}$ angle, with stone walls bound by clay (Structure No. 1/72). According to V. Dohnal, it was an above-ground farm building. The second building (Structure No. 1/74) was situated in squares 10/74-12/74. It was also a lighter construction, possibly a shelter or a log structure building connected by nails; its walls were probably not daubed with clay. The analysis of the excavated finds does not contribute much to a change in their interpretation presented by the head of the research, even though a pottery assemblage from Structure No. 74 also justifies considering its residential function. If attempting to interpret the built-up area of the outer bailey as a whole, it is possible to consider it a "latrán", i.e. the fortified part of the outer bailey, which did not have town privileges and a church building.

The analysis of the excavated finds proved that the core of the occupation in the outer bailey of Tepenec can be dated to the period of the functioning of the castle. The pottery assemblage is dominated by so-called white earthenware with a granular surface (65\%), which is especially typical of the 14th century in the Olomouc region. Grey reduction-fired pottery with a sporadic granular surface (20\%) and incoming brick-coloured hard-fired earthenware (11.5\%), which started to appear in the Olomouc region after 1400, are also considerably represented.

The presented results of the research of medieval occupation in the outer bailey of Tepenec Castle represent one of the first more comprehensive attempts at investigating this important Central Moravian site. It appears that the analysis of artifacts found in the unearthed features dated to the High Middle Ages will be crucial for further research, as it may contribute to a closer interpretation of the whole outer bailey of Tepenec Castle.

\section{Kontakt}

\section{Lukáš Hlubek}

Vlastivědné muzeum v Olomouci

Náměstí Republiky 5

CZ-771 73 Olomouc

hlubek@vmo.cz 
